UNIVERSIDADE DE SÃO PAULO

INSTITUTO DE GEOCIENCIAS

\title{
ESTUDO DA ANOMALIA DE CROMO NAS ÁGUAS SUBTERRÂNEAS DA REGIĀO NOROESTE DO ESTADO DE SĀO PAULO
}

Marta Lúcia Nunes Almodovar

Orientador: Prof. Dr. Alberto Pacheco

DISSERTAÇÃO DE MESTRADO

COMISSÃO JULGADORA

Presidente:

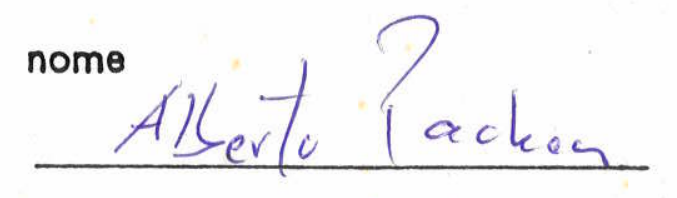

ass.

Examinadores:

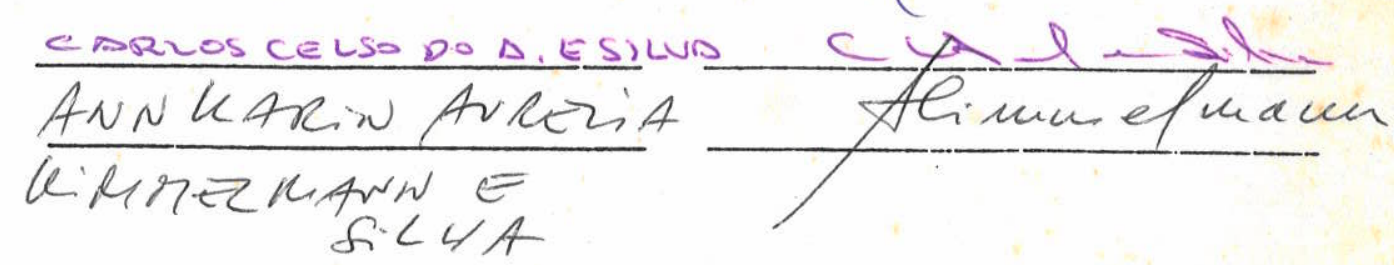




\title{
UNIVERSIDADE DE SÃO PAULO \\ INSTITUTO DE GEOCIENCIAS \\ DEDALUS - Acervo - IGC

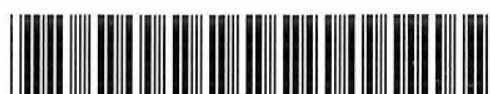 \\ 30900005946
}

\section{ESTUDO DA ANOMALIA DE CROMO NAS ÁGUAS SUBTERRÂNEAS DA REGIĀO NOROESTE DO ESTADO DE SÃO PAULO}

\author{
Marta Lúcia Nunes Almodovar
}

Orientador: Prof. Dr. Alberto Pacheco

\section{DISSERTAÇÃO DE MESTRADO}

Programa de Pós-Graduação em Recursos Minerais e Hidrogeologia

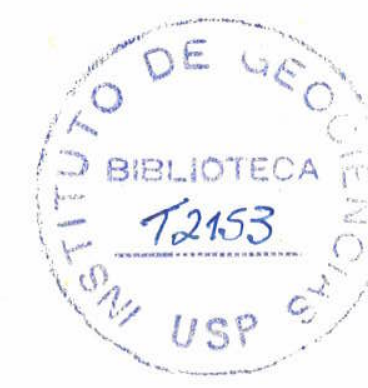

São Paulo

1995 


\section{SUMÁRIO}

\section{ANEXOS}

FIGURAS

GRÁFICOS

TABELAS

AGRADECIMENTOS

RESUMO

ABSTRACT

\section{INTRODUÇÃO}

1.1.Generalidades 1

1.2.Objetivos 2

2. AREA DE ESTUDO

2.1.Localização e vias de acesso

2.2.Aspectos fisioclimatológicos 3

2.3.Geologia 4

2.3.1.Grupo Bauru 4

2.3.2.Formação Serra Geral $\quad 8$

$\begin{array}{ll}\text { 2.4.Hidrogeologia } & 10\end{array}$

2.4.1.Sistema Aquífero Bauru $\quad 10$

2.4.2.Sistema Aquífero Serra Geral 12

\section{GEOQUÍMICA DO CROMO:UMA SÍNTESE BIBLIOGRAFICA}

3.1.Histórico

3.2.Propriedades físicas e químicas $\quad 14$

3.3.Produção industrial e uso $\quad 15$ 
3.4. Ocorrência na natureza

3.4.1.Nos sistemas vivos

3.4.2.Nas rochas e solos

3.4.3.Nas águas

3.5.Fontes de poluição

3.6.Aspectos de legislação

\section{METODOLOGIA}

4.1.Caracterização da ocorrência de cromo nas águas subterrâneas do noroeste do Estado de São Paulo

4.1.1.Cromo total

4.1.2. Cromo hexavalente

4.1.3.Cromo total, hexavalente e nitrogênio nitrato nas águas subterrâneas de Urânia

4.1.4.Cromo total e hexavalente em poços selecionados de Urânia e Santa Salete

4.1.5.Cromo total em poços perfurados apenas no Grupo Bauru ou em poços com entradas de água apenas na Formação Serra Geral

4.2.Cadastramento de poços tubulares

4.3.Avaliação geoquímica das águas, sedimentos e rochas basálticas de Urânia-S.P

4.3.1.Análises de águas

4.3.2.Análise dos sedimentos de Urânia e do poço 9

4.3.3.Análise dos basaltos do poço 9

4.4.Levantamento sobre eventuais problemas de saúde da população abastecida por águas subterrâneas com teores de cromo acima do limite de potabilidade 


\section{APRESENTAÇAOO DOS RESULTADOS}

5.1.Caracterização da ocorrência de cromo nas águas subterrâneas do noroeste do Estado de São Paulo

5.1.1.Cromo total

5.1.2. Cromo hexavalente

5.1.3.Cromo total, hexavalente e nitrogênio nitrato nas águas subterrâneas de Urânia

5.1.4. Cromo total e hexavalente em poços selecionados de Urânia e Santa Salete

5.1.5. Cromo total em poços perfurados apenas no Grupo Bauru ou em poços com entradas de água apenas na Formação Serra Geral

5.2.Avaliação geoquímica das águas, sedimentos e rochas basálticas de Urânia-S.P

5.2.1. Análises de águas

5.2.2.Análise dos sedimentos de Urânia e do poço 9

5.2.3.Análise dos basaltos do poço 9

5.3.Levantamento sobre eventuais problemas de saúde da população abastecida por águas subterrâneas com teores de cromo acima do limite de potabilidade

7.CONCLUSÕES

8.RECOMENDAÇÕES 
Anexo 01: Cadastro de poços tubulares da região noroeste do Estado de São Paulo

Anexo 02: Análises das águas subterrâneas feitas pela SABESP em 54 localidades da região noroeste do Estado de São Paulo Anexo 03: Descrição sucinta das 11 amostras de basaltos do poço 9 em Urânia, a diferentes profundidades

\section{FIGURAS}

Figura 01: Área de localização da pesquisa

Figura 02: Mapa de distribuição de Grupo Bauru no Estado de São Paulo

Figura 03: Diagrama da especiação do cromo em relação ao $\mathrm{pH}$ e Eh

Figura 04: Região Noroeste do Estado de São Paulo com as concentrações de cromo total e hexavalente nas águas subterrâneas

Figura 05: Esboço do perfil geológico do poço 9 em Urânia

Figura 06: Localização de poços tubulares e de pontos de amostragem de sedimentos na sede do município de Urânia

\section{GRAFICOS}

Gráfico 1A: Variação dos teores de cromo hexavalente $(\mathrm{mg} / \mathrm{l})$ com o pH

Gráfico 1B: Variação dos teores de cromo hexavalente (mg/l) 
com a condutividade elétrica $(\mu \mathrm{S} / \mathrm{cm})$

Gráfico 1C: Variação dos teores de cromo hexavalente (mg/l)

com os sólidos totais dissolvidos

Gráfico 2A: Concentrações de cromo total $(\mathrm{mg} / \mathrm{l})$ com a data de coleta do poço 1 em Urânia

Gráfico 2B: Concentrações de cromo total, hexavalente e nitrato com a data de coleta do poço 1 em Urânia

Gráfico 3A: Concentrações de cromo total (mg/l) com a data de coleta do poço 2 em Urânia

Gráfico 3B: Concentrações de cromo total, hexavalente e nitrato com a data de coleta do poço 2 em Urânia

Gráfico 4A: Concentrações de cromo total (mg/l) com a data de coleta do poço 3 em Urânia

Gráfico 4B: Concentrações de cromo total, hexavalente e nitrato com a data de coleta do poço 3 em Urânia

Gráfico 5A: Concentrações de cromo total (mg/l) com a data de coleta do poço 4 em Urânia

Gráfico 5B: Concentrações de cromo total, hexavalente e nitrato com a data de coleta do poço 4 em Urânia

Gráfico 6A: Concentrações de cromo total $(\mathrm{mg} / \mathrm{l})$ com a data de coleta do poço 5 em Urânia

Gráfico 6B: Concentrações de cromo total, hexavalente e nitrato com a data de coleta do poço 5 em Urânia

Gráfico 7A: Concentrações de cromo total (mg/l) com a data de coleta do poço 6 em Urânia

Gráfico 7B: Concentrações de cromo total, hexavalente e nitrato com a data de coleta do poço 6 em Urânia

Gráfico 8A: Variação dos teores de cromo total (mg/l) nos poços de 
Urânia e Santa Salete com o tempo

Gráfico 8B: Variação dos teores de cromo hexavalente $(\mathrm{mg} / \mathrm{l})$ nos poços de Urânia e Santa Salete com o tempo

\section{TABELAS}

Tabela 01: Características numéricas do cromo

Tabela 02: Concentrações de cromo (ppm) encontradas em rochas ígneas e sedimentares

Tabela 03: Resultados das análises físico-químicas das águas subterrâneas das 12 localidades do noroeste paulista

Tabela 04: Parâmetros analisados nas coletas de água dos poços de Urânia e Santa Salete

Tabela 05: Concentrações de cromo total (mg/l) em poços perfurados apenas no Grupo Bauru e poços com entradas de água apenas na Formação Serra Geral

Tabela 06: Resultados das análises físico-químicas de águas subterrâneas do poço 9 , em três profundidades

Tabela 07: Resultados das análises de parâmetros físico-químicos das águas subterrâneas dos poços da Fazenda Jatobá e Posto Garção

Tabela 08: Concentrações (ppm) de alguns elementos analisados nos sedimentos do poço 9 em Urânia

Tabela 9: Abundância média dos elementos em folhelhos (ppm)

Tabela 10: Concentrações (ppm) de alguns elementos analisados nos bașaltos do poço 9 em Urânia

Tábela 11: Abundância média dos elementos em basaltos (ppm) 


\section{AGRADECIMENTOS}

A realização desta pesquisa foi possível graças ao apoio de várias pessoas e instituições, as quais deixo registrado os meus agradecimentos.

Ao Instituto de Geociências da Universidade de São Paulo (IGc/USP), em particular ao Departamento de Geologia Econômica e Geofísica Aplicada (DGE) e ao Centro de Pesquisas de Águas Subterrâneas (CEPAS), por permitir a utilização de sua infra-estrutura.

Ao meu orientador Professor Doutor Alberto Pacheco.

Aos Professores Doutores do DGE, Uriel Duarte, Annkarin Aurélia Kimmelmann, José Milton Benetti Mendes e Raphael Hypólito, pelas sugetões e correções.

Ao Professor Doutor Valdecir de A. Janasi, do Departamento de Mineralogia e Petrologia (DMP-IGc/USP), pelo acompanhamento, discussões e correções nos estudos geoquímicos.

Ao Professor Doutor Wilson Teixeira do Departamento de Geologia Geral (DGG-IGc/USP), por facilitar a utilização do Laboratório do CPGEO.

À Professora Doutora Mária Szikszay, do IGc/USP, por sua valiosa contribuição.

À bibliotecária do IGc/USP, Maristela Prestes Severino, pelas correções bibliográficas.

À Companhia de Saneamento Básico do Estado de São Paulo (SABESP), por todo apoio durante a realização da pesquisa, em especial a:

- Maurício Souto Mayor Júnior, Roberto Ferreira, João Carlos Simanke de Souza, Antonio Jorge Sápio (SABESP-São Paulo);

- Edmilson A. Granello e Paulinho (SABESP-Fernandópolis);

- Sérgio Donizete Giovanini (SABESP-Urânia);

- Antônio Dirceu Pigato Azevedo (SABESP-Lins). 
À Secretaria de Estado da Saúde por sua colaboração, em especial a Denise M. E. Formaggia, Maria Adelaide Perrone e Arnaldo M. Elmec.

À Coordenação de Aperfeiçoamento de Pessoal de Nível Superior (CAPES), pela bolsa de mestrado que recebi durante o programa de pós-graduação.

À Fundação de Amparo à Pesquisa do Estado de São Paulo, pelo auxílio financeiro para esta pesquisa, através do processo número 94/1995-3.

Aos amigos:

- Ricardo C. A. Hirata, que muito batalhou para que esta pesquisa se concretizasse. Pelo apoio, incentivo, sugestões, discussões e até por fazer aquelas "perguntas chatas";

- Itabaraci N. Cavalcante, por todas as informações que me passou desde que ingressei na pós-graduação, pelas correções do texto, sugestões e pela dedicação com que realizou a leitura;

- Oscar Bordon, que perdeu suas horas de sono e Sandra M. D. Moraes, que descobriu o detalhe final e muito me ajudaram na confecção dos gráficos da dissertação. Pela convivência e por me incentivar naqueles dias dificeis.

- Alous Spaanderman pela importante ajuda.

E ao Zé Galinha, que transformou aqueles "dias de cão" em horas amenas. 


\section{RESUMO}

A ocorrência de cromo nas águas subterrâneas da região noroeste do Estado de São Paulo tem se configurado como uma grande preocupação, uma vez que as cidades possuem no recurso hídrico subterrâneo a única fonte de água para suprir suas necessidades. O sistema aquífero Bauru atende a uma ampla demanda de água, desde núcleos urbanos de pequeno porte e indústrias, até propriedades rurais que necessitam de água para irrigação.

Esta pesquisa objetiva caracterizar a extensão espacial da anomalia de cromo nas águas subterrâneas da região noroeste paulista; desenvolver um estudo geoquímico das águas, sedimentos e rochas da cidade de Urânia; definir a relação saúde pública e a presença de cromo nas águas subterrâneas utilizadas para abastecimento público.

Inicialmente, a anomalia de cromo foi detectada em poços tubulares e cacimbas do município de Urânia, região de Jales, sendo que em alguns locais, a presença deste elemento supera o valor máximo permissível em águas para consumo humano, que é de 0,05mg/l (Decreto Estadual 12.486, de 20-10-78 e Portaria 36, do Ministério da Saúde, de 19-01-90).

Com as análises químicas de águas subterrâneas de 54 localidades no período de 1977 a 1993, executadas pela Companhia Estadual de Saneamento Básico (SABESP), sabe-se hoje em dia, que esta anomalia extende-se a outros municípios da região noroeste do Estado.

Estudos geoquímicos dos sedimentos da Formação Adamantina e rochas basálticas da Formação Serra Geral da cidade de Urânia, mostraram que enquanto as concentrações de cromo nos primeiros estão acima da média encontrada em sedimentos similares da crosta terrestre, nas rochas basálticas, as concentrações estão abaixo da média dos basaltos da crosta.

Um levantamento sobre a saúde da população de Urânia mostrou que não foi realizado nenhum estudo na região que comprovasse doenças causadas pela 
ingestão de água contendo cromo acima do limite de potabilidade.

Através da integração dos dados e do estudo sistemático dos teores de cromo nas águas, sedimentos e rochas, chegou-se as seguintes conclusões:

- a anomalia de cromo extende-se além da cidade de Urânia, a outros municípios e distritos do noroeste paulista;

- a distribuição das concentrações de cromo é irregular, tanto temporal quanto espacialmente;

- a origem do cromo é discutível, apesar de fortes evidências de ser natural (a anomalia estar distribuída por uma ampla região, de serem encontradas altas concentrações de cromo nos sedimentos), são necessários estudos mais aprofundados;

- não se tem conclusões relevantes se a anomalia de cromo causa problemas à saúde da população abastecida por estas águas. 


\section{ABSTRACT}

The existence of chromium in groundwater is subject to great concern in the northwestern region of São Paulo State, where cities depend on the underground water resources for their only source of water to supply its needs. The aquifer system of Bauru attends with an ample demand of water the small urban centers and industries, and rural properties which need water for irrigation.

This research aims to characterize the spatial extension of the chromium anomaly in groundwater in the northwestern region of São Paulo State; to develop a geochemical study of water, sediments and rocks in the city of Urânia; and to define the relation between public health and the presence of chromium in groundwater for public consumption.

Initially, the chromium anomaly was discovered in shaft wells and waterholes in the Urânia municipality, Jales Region, that is to say, in some places the presence of this element exceeded the allowed maximum value in water for human consumption, which is $0.05 \mathrm{mg} / \mathrm{l}$ (State Decree 12.486, of 20-10-78 and Edict 36, of the Ministry of Health).

With the chemical analysis of groundwater taken at 54 locations during 19771993, executed by the State Company of Basic Sanitation (SABESP), we know today that this anomaly extends to other municipalities in the northwestern region of São Paulo State.

Geochemical studies in Urânia city of sediments of the Adamantina Formation and of the basaltic rocks of the Serra Geral Formation, show that the concentrations of chromium in the first formation are above the average found in similar sediments of the earth's crust, and the concentrations in the basaltic rocks are lower than the average in basaltic crust.

A survey to the health of the population in Urânia showed that no research was carried out in the region that would prove illness caused by the intake of water containing chromium rates above the limit for drinkability. 
Through the combination of data and the systematic study of chromium levels in water, sediments and rocks, the following conclusions were drawn:

- the chromium anomaly is not only present in the city of Urânia, but also in other municipalities and districts in the northwest of São Paulo State;

- the distribution of chromium concentrations is irregular, both in time and space;

- the origin of the chromium is subject to discussion, despite strong evidence that it is natural (the anomaly is distributed in a wide region, high chromium concentrations are found in the sediments), however, more in-depth studies are necessary;

- no relevant conclusions can be drawn about the problems caused by the chromium anomaly to the health of the population served by this water. 


\section{INTRODUÇÃO}

\subsection{GENERALIDADES}

A presença da anomalia de cromo nas águas subterrâneas da região noroeste do Estado de São Paulo tem sido verificada desde 1977. Inicialmente, foi constatada em águas provenientes de poços profundos e cacimbas no município de Urânia, região de Jales. Posteriormente, foi detectado que esta anomalia extendia-se a outros municípios do noroeste paulista.

As concentrações de cromo são variáveis em cada município e em alguns locais ultrapassam os limites máximos permitidos em águas para o consumo humano, cujo valor é 0,05 mg/l (Decreto Estadual 12.486 de 20-10-78 e Portaria 36, do Ministério da Saúde, de 19-01-90).

As cidades paulistas da região onde ocorre a anomalia de cromo têm no recurso hídrico subterrâneo a única fonte capaz de suprir suas necessidades. Como as águas são usadas para consumo humano, há uma grande preocupação, uma vez que a alta concentração de cromo é um potencial de risco à saúde pública. A toxicidade do cromo depende de seu estado de oxidação, que pode ser $\mathrm{Cr}^{3+}$ (trivalente) ou $\mathrm{Cr}^{6+}$ (hexavalente), sendo o primeiro menos tóxico do que o segundo, que pode causar tumores malígnos, como câncer no pulmão.

Esta pesquisa foi desenvolvida na região noroeste paulista, onde foi constatada a anomalia do cromo. Ela é parte de um projeto onde estiveram envolvidos, como órgãos de apoio, a Secretaria do Meio Ambiente através do Instituto Geológico, a Companhia Estadual de Saneamento Básico (SABESP) através da Diretoria de Projetos do Interior, a Secretaria de Estado da Saúde, através do Centro de Vigilância Sanitária (CVS) do CEATOX e Centro de Vigilância Epidemiológica (CVE) e o Instituto Adolfo Lutz. 
Desta forma, justifica-se o estudo desenvolvido, pois além da preocupação com a qualidade das águas subterrâneas e a saúde pública, esta pesquisa é de interesse acadêmico, uma vez que em um trabalho preliminar feito pelo Instituto Geológico, aventuou-se a hipótese de que a origem do cromo é natural, fato raro de ocorrência, inclusive no mundo. Como a presença deste elemento afeta a qualidade das águas subterrâneas, recurso de grande importância social, econômica e estratégica, foi necessário um estudo mais abrangente da região, a fim de averiguar a ocorrência da anomalia de cromo nestas águas, para que fosse possível buscar formas de amenização do problema.

\subsection{OBJETIVOS}

Os objetivos são:

- caracterizar a extensão espacial da anomalia de cromo nas águas subterrâneas da região noroeste do Estado de São Paulo;

- desenvolver um estudo geoquímico das águas, sedimentos e rochas da cidade de Urânia- S.P.;

- definir a relação saúde pública e a presença de cromo nas águas subterrâneas utilizadas para abastecimento público. 


\section{AREA DE ESTUDO}

\subsection{LOCALIZAÇÃO E VIAS DE ACESSO}

A área onde foi desenvolvido o trabalho está localizada na região noroeste do Estado de São Paulo. Foi selecionado o município de Urânia para estudo de detalhe (Figura 01).

A sede municipal de Urânia dista $594 \mathrm{~km}$ da capital, com acesso pelas rodovias SP 330, SP 310 e SP 320. A cidade possui aproximadamente 8.100 habitantes. $\mathrm{O}$ abastecimento de água é feito por poços tubulares e cacimbas, operados pela SABESP.

\subsection{ASPECTOS FISIOCLIMATOLÓGICOS}

A área de estudo situa-se no Planalto Ocidental, onde predominam os sedimentos do Grupo Bauru. Este planalto abrange cerca de $50 \%$ do território paulista, ocupado por relevos monótonos de colinas e morrotes.

Segundo Setzer \& Porto (1979) os solos do Grupo Bauru podem ser divididos em dois grupos: solos arenosos quase sem cimento calcífero e solos arenosos com cimento calcífero.

$\mathrm{Na}$ região de estudo domina a massa equatorial continental e a continental tropical e, em segundo plano, as massas polares. O período de chuva ocorre de dezembro a março e o período de seca de abril a setembro. A temperatura segue um ritmo normal de clima tropical, com duas estações bem definidas: uma quente, com médias mensais acima de $20{ }^{\circ} \mathrm{C}$ (dezembro/março) e outra com temperaturas abaixo de $19{ }^{\circ} \mathrm{C}$ (abril/setembro), sendo que em alguns anos se extende até novembro 
devido à presença de massas frias. Os índices pluviométricos anuais médios chegam a $1050 \mathrm{~mm}$ (DAEE, 1976).

\subsection{GEOLOGIA}

$\mathrm{Na}$ área de estudo onde foi investigada a presença de cromo nas águas subterrâneas, afloram os sedimentos da Formação Adamantina, do Grupo Bauru. Estes sedimentos encontram-se sobre os basaltos da Formação Serra Geral conforme atestam os poços tubulares da região.

\subsubsection{GRUPO BAURU}

Este Grupo é do Cretácio Superior e aflora em grande parte do Estado de São Paulo, recobrindo as lavas basálticas do Planalto Ocidental.

No Mapa Geológico do Estado de São Paulo, escala 1: 500.000, (IPT, 1981)

adotou-se a sequência estratigráfica que vem sendo proposta atualmente para o Grupo Bauru, subdividindo-o nas formações Caiuá, Santo Anastácio, Adamantina e Marília.

\section{Formação Caiuá}

A Formação Caiuá, constituída essencialmente de arenitos, representa o início da deposição do Grupo Bauru, em um embaciamento ainda restrito, sobrepondo-se às eruptivas da Formação Serra Geral. Sua área de afloramento no Estado 


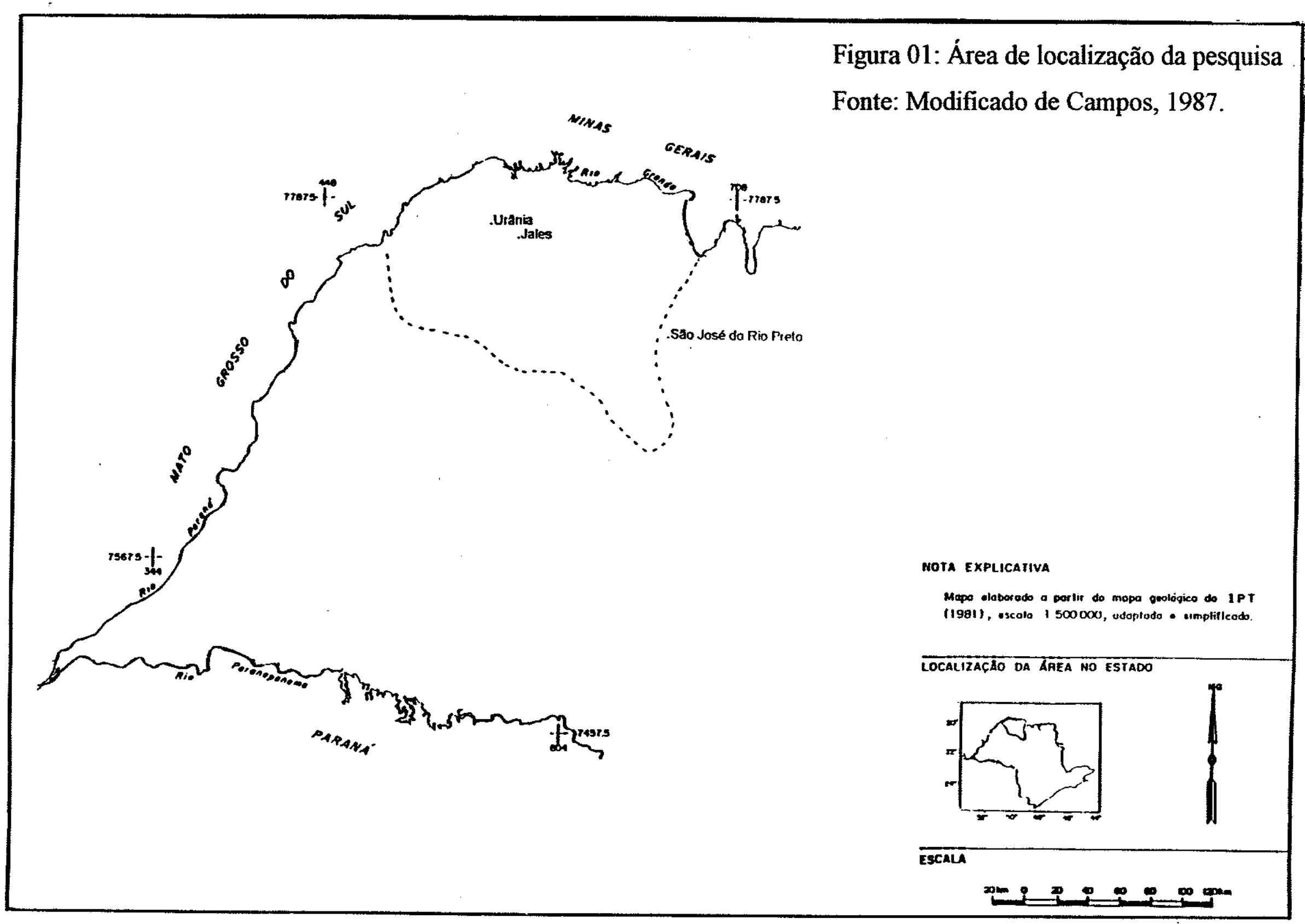


compreende a região do Pontal do Paranapanema, estendendo-se para norte por uma estreita faixa na margem esquerda do rio Paraná, mapeável até a confluência com o rio Peixe. Tem continuidade pelos estados do Paraná e Mato Grosso do Sul (IPT,1981).

\section{Formação Santo Anastácio}

Os arenitos desta formação afloram em áreas que acompanham as cotas mais baixas dos vales dos rios afluentes do Paraná, no oeste do Estado. Em subsuperficie, litologias atribuídas à Formação Santo Anastácio estendem-se para leste, até a região de Paraguaçu Paulista, e para norte, até o divisor entre os rios São José dos Dourados e Grande. Esta distribuição indica que o embaciamento em que se acumulou esta formação transgrediu sobre o embaciamento Caiuá, embora em continuidade tectônica e sedimentar. Encontra-se o Arenito Santo Anastácio depositado ora sobre o Caiuá, ora recobrindo diretamente o embasamento basáltico (IPT,1981).

\section{Formação Adamantina}

Aflora na região de estudo e ocorre por vasta extensão do oeste do Estado de São Paulo, constituindo os terrenos da maior parte do Planalto Ocidental, só deixando de aparecer nas porções mais rebaixadas dos vales dos principais rios, onde já foi removida pela erosão. Soares et al. (1980) propõem formalmente a denominação Formação Adamantina para designar os bancos de arenitos alternados com lamitos, siltitos e arenitos lamíticos, situados estratigraficamente entre a Formação Santo Anastácio, desmembrada como uma unidade sotoposta 
litologicamente diferenciada, de ocorrência mais restrita, e a Formação Marília, individualizada como uma unidade sobreposta, de ocorrência localizada.

Almeida et al. (1980) destacam que as características distintivas mais marcantes entre a Formação Santo Anastácio e a Formação Adamantina são que esta última tende, no geral, a apresentar sedimentos mais finos e bem selecionados, frequentemente com mica e mais raramente feldspato, sílica amorfa e opacos e com maior variedade de estruturas sedimentares. Estas características indicam maior maturidade textural e mineralógica, deposição em sistema flúvio-lacustre mais organizado que aquele da Formação Santo Anastácio, bem como maior diferenciação das áreas-fonte de sedimentos para a Formação Adamantina que, segundo Coimbra (1976), compreenderiam principalmente áreas de sedimentos fanerozóicos pré-existentes a noroeste e sudeste, áreas de rochas básicas do Grupo São Bento, metamóficas dos Grupos Araxá e Canastra e alcalinas do Triângulo Mineiro a nordeste. As conclusões deste autor basearam-se principalmente na análise da distribuição de parâmetros granulométricos e da frequencia relativa de minerais pesados, entre eles cianita, turmalina, granada, epídoto, estaurolita e rutilo.

Brandt Neto (1977) estudando a Formação Adamantina na região de Araçatuba e Penápolis, no Baixo Tietê, observou em trinta e oito amostras que a ocorrência de minerais pesados se concentrou em turmalina e estaurolita, predominantemente, e granada, zircão, rutilo e perowskita, secundariamente. Os argilo-minerais reconhecidos por Brandt Neto (1984) e Brandt Neto et al. (1985) são a caulinita, montimorillonita e paligosrquita.

Silva \& Monte (1987) descrevem a presença de trona no Grupo Bauru, mineral de origem evaporítica, não marinha, constituído essencialmente por carbonatos e bicarbonatos de sódio.

As maiores espessuras da Formação Adamantina ocorrem geralmente nas porções ocidentais dos espigões entre os grandes rios. Atinge 160 metros entre os Rios São José dos Dourados e Peixe, 190 metros entre os Rios Santo Anastácio e 
Paranapanema, e 100 a 150 metros entre os Rios Peixe e Turvo, adelgando-se destas regiões em direção a leste e nordeste (Soares et al., 1980).

\section{Formação Marília}

Ocorre na porção centro-sul do Estado, entre os médios vales dos rios Tietê e Paranapanema. Tem ocorrência restrita relativamente às demais formações do Grupo Bauru, sendo que a linha de contato desenha um intrincado recorte, resultando da erosão ao longo da drenagem principal. Nas regiões de Marilia e Echaporã sustenta escarpas características, com até pouco mais de uma centena de metros de desnível, encimadas por uma superfície aplainada denominada Planalto de Marília-Garça-Echaporã ou Planalto de Marília. A Formação Marilia depositou-se em um embaciamento localizado desenvolvido ao término da deposição Bauru, em situação parcialmente marginal, repousando geralmente sobre a Formação Adamantina, e, mais para leste, diretamente sobre os basaltos Serra Geral (IPT, 1981).

$\mathrm{Na}$ figura 02 encontra-se o mapa de distribuição do Grupo Bauru no Estado de São Paulo.

\subsubsection{FORMAÇÃO SERRA GERAL}

A Formação Serra Geral pertence ao Grupo São Bento e segundo White, (1908 apud IPT, 1981) compreende um conjunto de derrames de basaltos toleíticos entre os quais se intercalam arenitos com as mesmas características dos pertencentes à Formação Botucatu. 


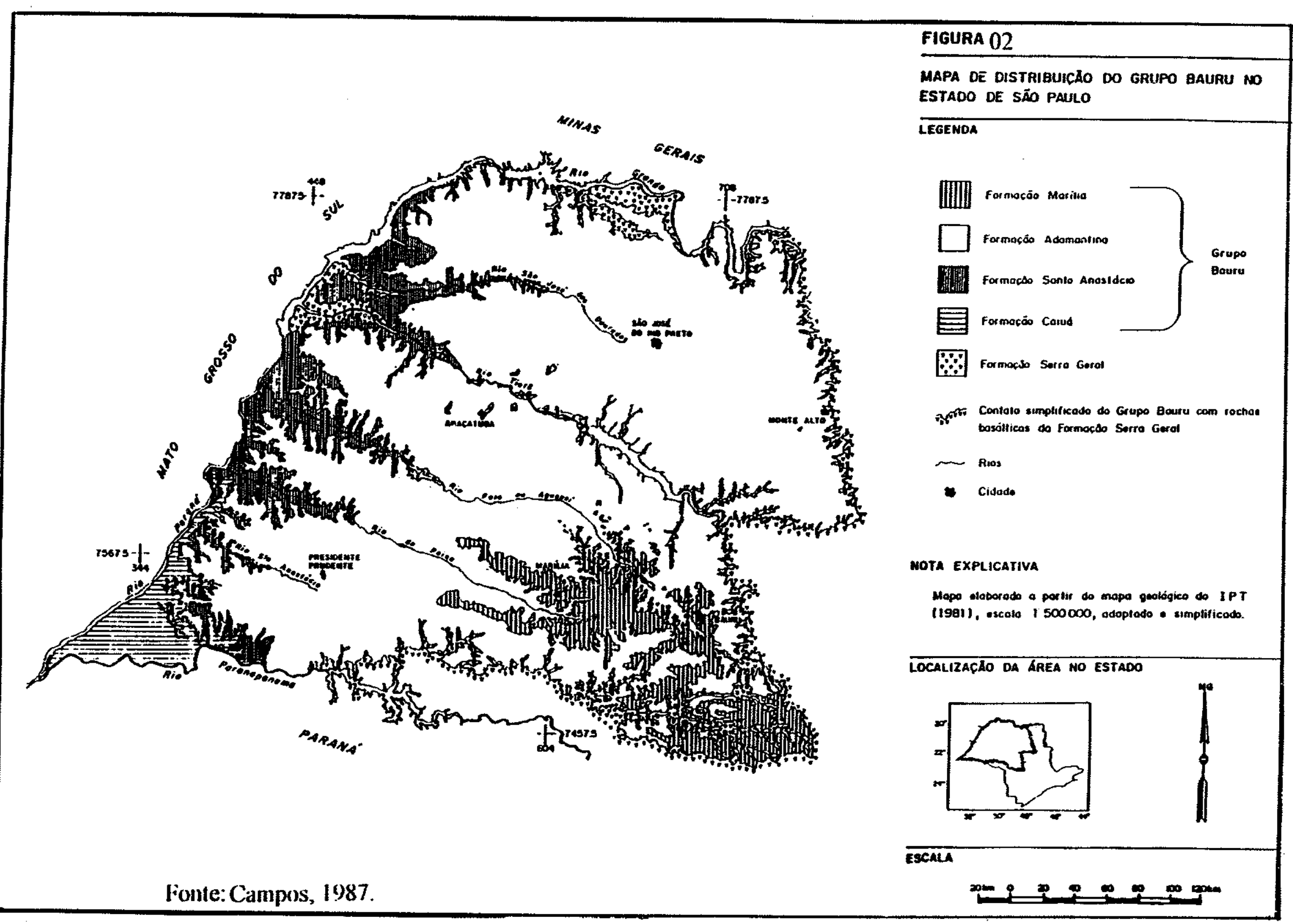


Os derrames são formados por rochas de cor cinza escura a negra, afaníticas. Petrograficamente os basaltos apresentam composição mineralógica simples, constituídos essencialmente de labradorita zonada associada a clinopiroxênios (augita e às vezes pigeonita). Acessoriamente mostram-se titano-magnetita, apatita, quartzo e raramente olivina ou seus produtos de transformação (IPT, 1981).

Ruegg (1975) reconhece a presença de cromo nas rochas basálticas como elemento traço, em concentrações que atingem até $240 \mathrm{ppm}$, com $25 \%$ das amostras com concentrações variando de 140 a 160 ppm.

\subsection{HIDROGEOLOGIA}

\subsubsection{SISTEMA AQUÍFERO BAURU}

Os sedimentos da Formação Adamantina formam o Sistema Aquífero Bauru, que representa uma das principais fontes de exploração de água subterrânea no Estado de São Paulo. Este aquífero cobre uma área de $104.000 \mathrm{~km}^{2}$ ( cerca de $40 \%$ do território estadual) de um total de $315.000 \mathrm{~km}^{2}$ de sua ocorrência na Bacia do Paraná. Devido à relativa facilidade de captação de água através de poços cacimbas e tubulares, o Sistema Aquífero Bauru atende a uma ampla demanda de água, desde núcleos urbanos de pequeno porte e indústrias, até propriedades rurais que necessitam de água para irrigação (Campos, 1987).

Segundo DAEE (1976 e 1988), o Sistema Aquífero Bauru caracteriza-se como unidade hidrogeológica de extensão regional, contínua, livre a semiconfinada, com espessura média de 100 metros, mas que pode chegar aos 250 metros. É explorado por cerca de 4.500 poços tubulares, utilizados basicamente para o abastecimento público. Há um zoneamento do potencial explorável por poços: a faixa de vazão explorável entre 5 e $20 \mathrm{~m}^{3} / \mathrm{h}$ é predominante em área; faixas de 20 - 
$30 \mathrm{~m}^{3} / \mathrm{h}$ e de $30-50 \mathrm{~m}^{3} / \mathrm{h}$ ocorrem em áreas menores, nas porções onde a parte inferior do pacote sedimentar tem expessura da ordem de 100 metros. Este aquífero apresenta valores de transmissividade que variam de 10 a $100 \mathrm{~m}^{2} / \mathrm{dia}$, com média de $35 \mathrm{~m}^{2} /$ dia, e a capacidade específica de $90 \%$ dos poços é inferior a $1 \mathrm{~m}^{3} / \mathrm{h} . \mathrm{m}$.

Segundo CETESB (1977), a porosidade efetiva varia de acordo com a composição das camadas, de $15 \%$ nas camadas arenosas a $5 \%$ nos arenitos calcíferos e siltosos. Alguns testes de bombeamento realizados em poços que exploram o Grupo Bauru, acusaram valores do coeficiente de armazenamento característicos de condições de confinamento, fato explicado pela existência de camadas arenosas limitadas por camadas silto-argilosas compactas formando bancos de grande extensão.

Como aquífero freático, a recarga é feita diretamente pela precipitação pluvial, sendo sua base de drenagem os rios Paranapanema, Tietê, Grande e Paraná, e suas malhas de afluentes em toda a área do afloramento. $\mathrm{O}$ aquífero funciona, em geral, como reservatório regulador do escoamento desta rede fluvial.

Segundo Rocha et al. (1979), o Bauru apresenta velocidades de circulação das águas subterrâneas da ordem de $4 \mathrm{~cm} /$ dia para as Formações Adamantina e Marília.

$\mathrm{Na}$ Formação Adamantina predominam águas bicarbonatadas cálcicas ou magnesianas e águas bicarbonatadas sódicas; secundariamente ocorrem águas clorosulfatadas cálcicas ou magnesianas e cloro-sulfatadas sódicas (Campos 1987). As águas são pouco mineralizadas, com sólidos totais dissolvidos (STD) inferiores à $240 \mathrm{mg} / \mathrm{l}$.

O Sistema Aquífero Bauru apresenta pH de ácido a básico $(4,59$ a 9,64) e teores salinos inferiores a $200 \mathrm{mg} / \mathrm{l}$ para $62 \%$ das amostras. Neste sistema aquífero, a grosso modo, o enriquecimento do teor salino das águas subterrâneas não é acompanhado pelo aumento dos teores de cloreto e de sódio, a não ser localmente (Campos, 1993). 


\subsubsection{SISTEMA AQUÍFERO SERRA GERAL}

Os derrames basálticos e intrusões diabásicas que originam a Formação Serra Geral não constituem, por si, camadas aquíferas; somente ao longo de linhas estruturais (falhas e fraturas), horizontes vesiculares, interderrames e arenitos intertrapeanos, é que se tem a produção de águas subterrâneas. Por se constituírem em aquíferos de fissuras, suas potencialidades relacionam-se à densidade de fraturamento, grau de alteração dos horizontes vesiculares, sistemas de alimentação e inter-relação com outros aquíferos, não podendo ser aferidas pelos parâmetros característicos dos aquíferos de interstícios, como porosidade e permeabilidade (CETESB, 1977).

O Sistema Aquífero Serra Geral aflora numa área de 32 mil quilômetros quadrados na porção centro-leste de São Paulo, sendo recoberto, a oeste, pelos sedimentos Bauru-Caiuá. Apresenta-se em derrames sucessivos de lavas, superpostos, onde os sistemas de fraturamento (zonas aquíferas) estão relacionados tanto a esforços tectônicos, gerando fraturas subverticais, como a processos de resfriamento que originam descontinuidades sub-horizontais. A maioria de seus poços tubulares possuem profundidades de 100 a 150 metros. Suas vazões, porém, são variáveis e os poços situados junto a lineamentos estruturais ou fraturas apresentam vazões de 10 a $100 \mathrm{~m}^{3} / \mathrm{h}$ (DAEE, 1988). 


\section{GEOQUÍMICA DO CROMO: UMA SÍNTESE BIBLIOGRÁFICA}

\subsection{HISTÓRICO}

O cromo não era conhecido na antiguidade, tendo sido descoberto em 1798 no cromato de chumbo $\left(\mathrm{PbCrO}_{4}\right)$, que ocorre na natureza sob a forma do mineral crocoíta (Pauling, 1966).

O metal foi isolado pela primeira vez através de um processo de redução de óxido de cromo $\left(\mathrm{CrO}_{3}\right)$ com carvão vegetal, a alta temperatura. Foi então sugerido o nome cromo ao metal, originário do grego, devido as diversas colorações dos seus compostos (Rollinson, 1973 apud Soares, 1992).

Segundo Soares (1992), inicialmente eram manufaturados alguns compostos químicos do cromo, produzidos bicromatos e pigmentos, como cromato de chumbo, sendo que no ano de 1845 iniciou-se a primeira produção comercial.

O elemento tornou-se economicamente viável por volta de 1827 , com a descoberta de grandes depósitos nos Estados Unidos da América. Em 1848 foram descobertas novas jazidas na Ásia Menor, que fez com que o monopólio americano fosse se desfazendo.

A utilização do metal e de seus compostos nos diversos setores industriais, comerciais e científicos foi melhor evidenciada a partir da Revolução Industrial. No entanto, o conhecimento de acidentes causados ao meio ambiente pelos compostos de cromo é um fato recente. 


\subsection{PROPRIEDADES FÍSICAS E QUÍMICAS}

O cromo é um metal branco, brilhante, duro e quebradiço, com ponto de fusão bastante alto $\left(1840^{\circ} \mathrm{C}\right)$ e ponto de ebulição não tanto proporcionalmente $\left(2300{ }^{\circ} \mathrm{C}\right.$ ). Sua densidade é $7,188 \mathrm{~g} / \mathrm{cm}^{3}$ (Ohlweiler, 1973). A tabela 01 relaciona algumas características numéricas importantes do elemento.

Tabela 01: Características numéricas do cromo.

\begin{tabular}{|c|c|}
\hline \multicolumn{2}{|l|}{ PROPRIEDADES DO CROMO } \\
\hline Número Atômico & 24 \\
\hline Configuração eletrônica externa & $3 d^{5} 4 s^{1}$ \\
\hline Peso atômico & 51,996 \\
\hline Densidade do sólido a $20^{\circ} \mathrm{C}, \mathrm{g} / \mathrm{cm}^{3}$ & 7,188 \\
\hline Volume atômico, $\mathrm{cm}^{3}$ & 7,24 \\
\hline Ponto de fusão, ${ }^{\circ} \mathrm{C}$ & 1840 \\
\hline Ponto de ebulição, ${ }^{\circ} \mathrm{C}$ & ca. 2300 \\
\hline Potencial de ionização, ev & 6,76 \\
\hline
\end{tabular}

Fonte: Ohlweiler, 1973, modificado

Este elemento pertence ao grupo VI-B da tabela periódica, com número atômico 24, peso atômico 51,996. Possui estados de oxidação que variam de $\mathrm{Cr}^{2-}$ à $\mathrm{Cr}^{6+}$, comumente ocorre nos estados 0 (elementar), $+2,+3,+4,+6$. Possui quatro isótopos estáveis com a seguinte porcentagem de abundância: ${ }^{50} \mathrm{Cr}(4,31 \%) ;{ }^{52} \mathrm{Cr}$ $(83,76 \%) ;{ }^{53} \mathrm{Cr}(9,55 \%)$ e ${ }^{54} \mathrm{Cr}(2,38 \%)$. Ele tem cinco isótopos radioativos, mas somente ${ }^{51} \mathrm{Cr}$, com meia-vida de 27,8 dias, é mais comumente usado para estudos de traçador. Possui dois estados de oxidação no ambiente natural: hexavalente $(\mathrm{Cr}$ (VI)) e trivalente (Cr (III)). 


\subsection{PRODUÇÃO INDUSTRIAL E USO}

Segundo "National Academy of Sciences"(1974 apud Soares, 1992), apesar de óxidos de cromo serem encontrados com abundância na crosta terrestre, não apresentam concentrações de cromo viável economicamente, sendo seu único minério a cromita, cuja fórmula é $\left[(\mathrm{Fe}, \mathrm{Mg}) \mathrm{O}(\mathrm{Cr}, \mathrm{Al}, \mathrm{Fe})_{2} \mathrm{O}_{3}\right]$. O último membro, $\mathrm{FeCr}_{2} \mathrm{O}_{4}$ (também chamado cromita), contém $68 \%$ de óxido de cromo $\left(\mathrm{Cr}_{2} \mathrm{O}_{3}\right)$ e $32 \%$ de óxido de ferro $(\mathrm{FeO})$. $\mathrm{O}$ grau mais alto do minério contém aproximadamente $52 \%$ a $56 \%$ de $\mathrm{Cr}_{2} \mathrm{O}_{3}$ e $10 \%$ a $26 \%$ de $\mathrm{FeO}$.

Os principais produtores de cromita tem sido a extinta U.R.S.S., África do Sul, Filipinas e Turquia. Outros depósitos de extração são encontrados nos E.U.A., Albânia, Cuba, Brasil, Japão, India, Nova Caledônia, Paquistão, Irã e outros.

A cromita sofre vários processos industriais até chegar aos produtos finais, utilizados nas indústrias metalúrgicas, de refratários e químicas.

\section{Indústrias metalúrgicas}

O cromo é extremamente resistente à corrosão, por isso é empregado como cobertura de proteção e decoração de outros metais (Mahan, 1972).

Suas ligas são muito importantes, principalmente as de $\mathrm{Fe}$ (II) (ligas de aço). Os aços que contêm cromo são muito duros, resistentes e fortes. São usados em projéteis, cofres etc. Aço inoxidável comum contém 14-18\% de $\mathrm{Cr}$ (e, em geral, 8\% de Ni) (Pauling, 1966). 


\section{Indústrias de refratários}

Utiliza-se a cromita com aproximadamente $34 \%$ de óxido de cromo e alta porcentagem de alumínio, devido ao alto ponto de fusão $\left(2040{ }^{\circ} \mathrm{C}\right)$ e baixa reatividade (Soares, 1992).

\section{Indústrias químicas}

Sais de cromo hexavalente são usados em decapagem química de metal e operações de capeamento, anodização do alumínio, curtimento do couro e em manufatura de tintas, corantes e outras substâncias. Sais de cromo trivalente são menos usados em indústrias e aplicações manufatureiras. Compostos de cromo têm sido usados como inibidor de corrosão em tubos condensadores de usinas elétricas (Stamer et al., 1985).

\subsection{OCORRÊNCIA NATUREZA}

O cromo é onipresente no meio ambiente, encontrado em concentrações variadas nas águas $(1 \mu \mathrm{g}$ até $112 \mu \mathrm{g} / \mathrm{l})$, no ar $\left(<0,1 \mu \mathrm{g} / \mathrm{m}^{3}\right)$, nas rochas (5 até $1800 \mathrm{mg} / \mathrm{kg})$, solos $(53 \mathrm{mg} / \mathrm{kg})$ e toda matéria biológica. Este elemento é encontrado em concentrações maiores do que os elementos cobalto, cobre, zinco, molibdênio, chumbo, níquel e cádmio. 


\subsubsection{NOS SISTEMAS VIVOS}

O organismo humano necessita de um série de substâncias químicas que são indispensáveis para a manutenção da vida. Estas substâncias podem ser divididas em dois grupos, os constituintes básicos (carbono, oxigênio, hidrogênio, nitrogênio, cálcio, fósforo, potássio, enxofre, sódio, cloreto, magnésio) e os elementos essenciais (cromo, cobalto, cobre, estanho, ferro, iodo, manganês, molibdênio, selênio e zinco). Os constituintes básicos são aqueles que existem em grandes quantidades, enquanto os elementos essenciais aparecem em pequenas quantidades e são denominados "traços".

Muitos metais traços são essenciais para a nutrição de animais e plantas em quantidades traço, mas podem tornar-se venenosos ou tóxicos quando as concentrações benéficas forem excedidas (Stamer et al., 1985).

As ações tóxicas se manifestam em função da dosagem, forma química e estado nutricional do organismo exposto. Desta forma, para garantir efeitos benéficos ao organismo, é preciso manter as concentrações dos elementos essenciais dentro dos limites. $O$ excesso ou a falta dos elementos traços podem induzir alterações bioquímicas que afetam as funções fisiológicas, provocando efeitos que variam em intensidade de acordo com a idade, sexo e espécie do organismo em estudo (Amaral, 1985).

A toxicidade do cromo e seus compostos depende de seu estado de oxidação, que pode ser +3 ou +6 . O cromo é um dos elementos traços menos tóxicos. Compostos de $\mathrm{Cr}$ (VI) são aproximadamente cem vezes mais tóxicos do que sais de Cr (III).

As formas trivalentes de cromo, que são nutricionalmente ativas, têm baixa toxicidade, apesar de não terem sido estabelecidas doses limites. Sabe-se que oralmente são pouco absorvidas; sobre a pele há combinações com as proteínas das camadas superiores mas sem causar ulcerações, com excessão de pessoas alérgicas 
ao cromo. O cromo hexavalente é muito mais tóxico e não apresenta valor nutricional. Este pode ser absorvido por ingestão, inalação e através da pele, podendo causar ulcerações e eczemas (Amaral, 1985).

$\mathrm{O}$ cromo em cromatos e ácido crômico é da forma hexavalente e em trióxido crômico é da forma trivalente. O ácido crômico é corrosivo para a pele e membranas da mucosa, na área respiratória superior. O cromo na forma trivalente é menos tóxico do que na forma hexavalente. Câncer no pulmão foi constatado em trabalhadọres que se expunham ao cromo hexavalente em indústrias de cromo, remoção de cobre e anodização de alumínio (Hagarty,1991).

A maioria das referências bibliográficas descreve estudos relacionados à assimilação de cromo por vias respiratórias, não tratando da ingestão de água contendo cromo.

$\mathrm{O}$ cromo presente no material biológico está na forma $\mathrm{Cr}$ (III), que é essencial à nutrição humana e desempenha um papel importante no metabolismo do glicogênio. $O$ tecido animal possui o elemento em concentrações variáveis dependendo da espécie, idade e área do corpo. Concentrações excepcionalmente elevadas têm sido encontradas no cérebro e, particularmente, na medula vertebral, bem como em tumores e tecidos carcinogênicos (Mertz, 1969).

No cabelo de crianças diabéticas foram encontradas concentrações inferiores às encontradas em crianças normais. Masironi, (1978 apud Amaral, 1985), coloca que o cromo age como cofator interveniente com a insulina no metabolismo da glicose e que a carência deste metal pode provocar os distúrbios verificados na diabete.

O cromo pode prevenir a ocorrência de problemas das coronárias. Estudos comparando as paredes arteriais de pacientes mortos por distúbios do coração e vítimas fatais de acidentes de trânsito, revelaram que a taxa de cromo era menor naqueles que sofreram crises cardíacas. Os riscos cardíacos parecem praticamente nulos quando a taxa de cromo é superior a 6 bilionésimos de grama. 


\subsubsection{NAS ROCHAS E SOLOS}

O cromo é um metal que ocorre frequentemente na natureza. Estudos geoquímicos mostram que está entre os quinze elementos mais abundantes na Terra e que, ao lado do $\mathrm{Na}, \mathrm{K}, \mathrm{Co}, \mathrm{P}, \mathrm{Mn}, \mathrm{Ti}$, pode ocorrer entre 0,1 e $1 \%$ do peso total da crosta terrestre. Sua composição média na crosta é de $100 \mathrm{~g} /$ ton (ppm), com valores diferenciados para o diabásio de $120 \mathrm{ppm}$ e para o granito de $20 \mathrm{ppm}$ (Mason, 1971).

A cromita $\left(\mathrm{FeCr}_{2} \mathrm{O}_{4}\right)$ é um constituinte comum dos peridotitos e dos serpentinitos deles derivados, sendo um dos primeiros minerais a se separar do magma que se resfria. Pensa-se que os grandes depósitos de cromita se teriam formado por esta diferenciação magmática. Comumente associa-se com a olivina, a serpentina e o coríndon (Dana, 1986). Pode estar concentrada em resíduos laterícos sobre rochas ultramáficas, que contêm maior concentração de cromo do que outras espécies de rochas (Hem, 1985).

Nas rochas sedimentares a presença de cromo pode estar associada a minerais de argila. A montmorillonita, um tipo específico de argila expansiva, comporta a substituição atômica de um considerável número de elementos em sua estrutura, incluindo o cromo trivalente. Nestes minerais o cromo não tem origem primária.

Nas rochas ígneas, o cromo está presente em piroxênios, um mineral silicático. Estes minerais têm uma composição altamente variável devido à substituição atômica. $\mathrm{O}$ elemento em questão pode ocorrer em até 1,2\% em alguns diopsídios [Ca $\left.\mathrm{Mg}\left(\mathrm{Si}_{2} \mathrm{O}_{6}\right)\right]$ e em algumas augitas [(Ca,Na) $\left(\mathrm{Mg}, \mathrm{Fe}_{2}, \mathrm{Fe}_{3}, \mathrm{Al}\right)(\mathrm{Si}$, $\left.\mathrm{Al}_{2} \mathrm{O}_{6}\right]$ (Mason, 1971).

A tabela 02 mostra as concentrações de cromo (ppm) encontrada em algumas rochas ígneas e sedimentares segundo vários autores. 
A concentração de cromo no solo pode ser determinada pelo material de origem. Solos derivados de rochas ígneas podem conter teores elevados, assim como solos derivados de folhelhos. Solos derivados de serpentinitos usualmente contêm alto teor de cromo. Serpentinitos contêm uma proporção de $1.800 \mathrm{ppm}$ de cromo e $2.000 \mathrm{ppm}$ de Ni. Em adição, argilas xistosas e fosforitos usualmente contêm altas concentrações.

Em solos com elevado teor de óxidos de manganês, foi constatada a possibilidade do $\mathrm{Cr}$ (III), forma relativamente estável, ser oxidado à forma de $\mathrm{Cr}$ (VI), de grande mobilidade no solo (Bartlett \& James, 1979). Porém, a redução de Cr (VI) no solo, pode ser aumentada com a presença de matéria orgânica (Carry et al., 1977; Bartlett \& Kimble, 1976).

Tabela 02: Concentrações de cromo (ppm) encontradas em rochas ígneas e sedimentares.

\begin{tabular}{|c|c|}
\hline MATERIAL & $\begin{array}{c}\text { CONCENTRAÇÃO } \\
\text { MÉDIA (ppm) }\end{array}$ \\
\hline Rocha ígnea $^{2}$ & 198 \\
\hline Granito $^{\circ}$ & 20 \\
\hline Diabásio $^{\circ}$ & 120 \\
\hline Arenito $^{2}$ & 120 \\
\hline Carbonato $^{2}$ & 7,1 \\
\hline
\end{tabular}

Fontes:

${ }^{a}$ Horn \& Adams, 1966 apud Hem, 1985

${ }^{b}$ Mason, 1971 


\subsubsection{NAS ÁGUAS}

O cromo (III) é pouco móvel nas águas subterrâneas e apresenta baixa toxicidade para o ser humano, se ingerido por via oral. Já o cromo (VI) é altamente móvel e possui alta toxicidade. Devido a possibilidade de oxidação do cromo (III) para o cromo (VI), nas normas de potabilidade da água é recomendado o valor máximo de $0,05 \mathrm{mg} / \mathrm{l}$ na forma de cromo total (Calder, 1988).

Hem (1985) cita que concentrações de cromo em águas de rios nãocontaminados são normalmente menores do que 0,01 mg/l. Durfor \& Becker (1964) reportam concentrações menores do que $0,00043 \mathrm{mg} / \mathrm{l}$ nas águas de abastecimento público e de $0,0058 \mathrm{mg} / \mathrm{l}$ nos rios dos E.U.A.

A mobilidade do cromo nas águas subterrâneas depende das características hidrogeológicas do local: especiação química e solubilidade do cromo e de sua tendência de ser adsorvido pelo material do aquífero.

\section{Especiação Química}

O cromo ocorre nas águas subterrâneas com diferentes graus de oxidação. Nos sistemas naturais, o cromo pode ser encontrado nas formas trivalente e/ou hexavalente. As espécies de $\mathrm{Cr}$ (III) que podem existir nas águas subterrâneas são: $\mathrm{Cr}^{3+}, \mathrm{Cr} \mathrm{OH}^{2+}, \mathrm{Cr}(\mathrm{OH})_{2}^{+}, \mathrm{Cr}(\mathrm{OH})_{3}{ }^{0}, \mathrm{Cr}(\mathrm{OH})_{4}{ }^{-}$. As espécies de $\mathrm{Cr}(\mathrm{VI})$ são: $\mathrm{HCrO}_{4}{ }^{-}$e $\mathrm{CrO}_{4}{ }^{2-}$.

A especiação do cromo nas águas subterrâneas depende do Eh (potencial de oxirredução ou redox) e das condições de $\mathrm{pH}$. O cromo (VI) predomina em condições de oxidação (Eh alto), enquanto o cromo (III) predomina em condições de redução (Eh baixo). 
$\mathrm{Na}$ figura 03 tem-se um diagrama de equilíbrio do cromo, do $\mathrm{pH}$ em função do Eh. Para as concentrações de cromo total abaixo de $500 \mathrm{mg} / \mathrm{l}$, as espécies

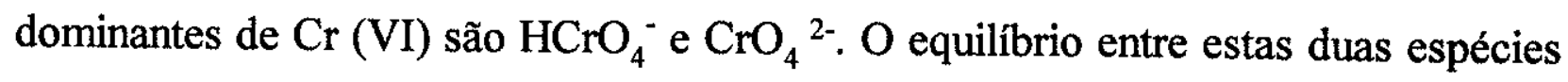
depende do $\mathrm{pH}$ :

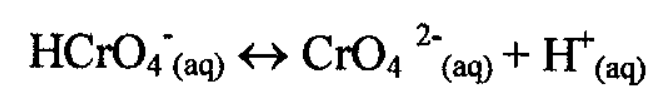

Para baixo $\mathrm{pH}$, a concentração dos íons $\mathrm{H}^{+}$é alta, a reação tende para a esquerda e $\mathrm{HCrO}_{4}{ }^{-}$é a espécie dominante. Para alto $\mathrm{pH}$, onde a concentração de $\mathrm{H}^{+}$ é baixa, a reação tende para a direita e predomina $\mathrm{CrO}_{4}{ }^{2-}$. Em águas subterrâneas naturais o pH está normalmente entre 6 e 8 e o íon $\mathrm{CrO}_{4}{ }^{2-}$ é a espécie dominante. Para concentração de Cr (VI) acima de $500 \mathrm{mg} / \mathrm{l}$, o íon $\mathrm{Cr}_{2} \mathrm{O}_{7}{ }^{2-}$ é predominante em ambientes ácidos (Baes \& Mesmer apud Calder, 1988). Porém, as concentrações de $\mathrm{Cr}$ (VI) em águas subterrâneas poluidas são geralmente menores do que $50 \mathrm{mg} / 1$.

A espécie de cromo (III) que ocorre na água subterrânea também depende do pH. As reações que governam são:

$$
\begin{gathered}
\mathrm{Cr}^{3+}{ }_{(\mathrm{aq})}+\mathrm{H}_{2} \mathrm{O}_{(\mathrm{l})} \leftrightarrow \mathrm{CrOH}^{2+}{ }_{(\mathrm{aq})}+\mathrm{H}^{+}{ }_{(\mathrm{aq})} \\
\mathrm{CrOH}^{2+}{ }_{(\mathrm{aq})}+\mathrm{H}_{2} \mathrm{O}_{(\mathrm{l})} \leftrightarrow \mathrm{Cr}(\mathrm{OH})_{2}^{+}{ }_{(\mathrm{aq})}+\mathrm{H}^{+}{ }_{(\mathrm{aq})} \\
\mathrm{Cr}(\mathrm{OH})_{2}{ }^{+}{ }_{(\mathrm{aq})}+\mathrm{H}_{2} \mathrm{O}_{(\mathrm{l})} \leftrightarrow \mathrm{Cr}(\mathrm{OH})_{3}{ }^{0}{ }_{(\mathrm{aq})}+\mathrm{H}^{+}{ }_{(\mathrm{aq})} \\
\mathrm{Cr}(\mathrm{OH})_{3}{ }_{(\mathrm{aq})}+\mathrm{H}_{2} \mathrm{O}_{(\mathrm{l})} \leftrightarrow \mathrm{Cr}(\mathrm{OH})_{4}^{-}{ }_{(\mathrm{aq})}+\mathrm{H}^{+}{ }_{(\mathrm{aq})}
\end{gathered}
$$

$\mathrm{Cr}(\mathrm{OH})_{2}{ }^{+}$é a espécie dominante nas águas subterrâneas naturais, com $\mathrm{pH}$ entre 6 e $8, \mathrm{CrOH}^{2+}$ e $\mathrm{Cr}^{3+}$ predominam em águas mais ácidas e $\mathrm{Cr}(\mathrm{OH})_{3}{ }^{0}$ e $\mathrm{Cr}(\mathrm{OH})_{4}{ }^{\circ}$ predominam em águas mais alcalinas. 


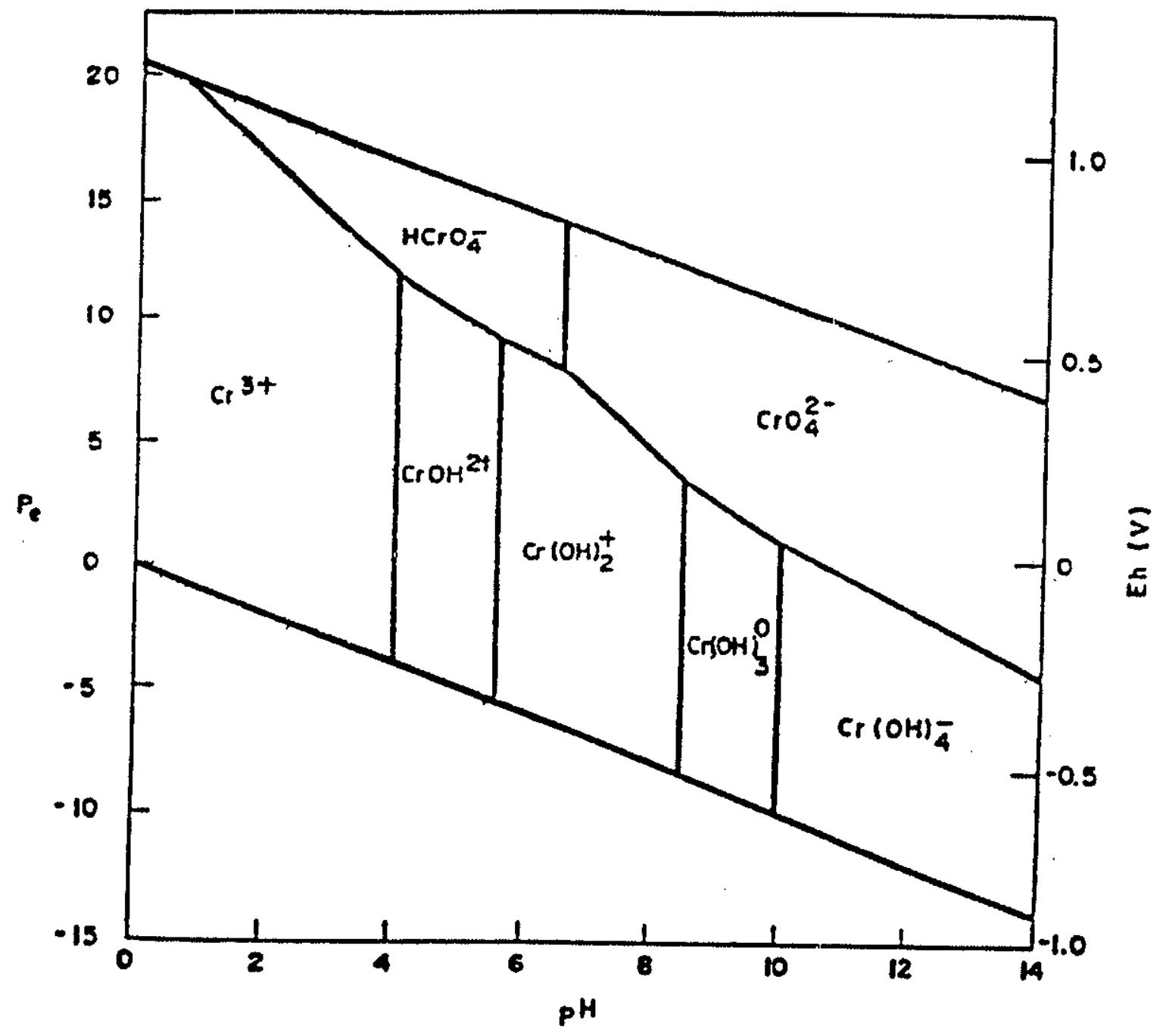

Figura 03: Diagrama da especiação do Cromo em relação ao pH e Eh (Calder, 1988) 


\section{Solubilidade}

Segundo Hem (1977 apud Calder ,1988), o cromo (III) geralmente forma uma pequena porcentagem da concentração do cromo total nas águas subterrâneas naturais ou poluidas e raramente ocorre para concentrações acima do padrão de água potável $(0,05 \mathrm{mg} / \mathrm{l})$. Devido à sua baixa solubilidade, tende a ser essencialmente imóvel em muitas águas subterrâneas. Já o cromo (VI) é móvel nas águas subterrâneas devido à sua alta solubilidade.

Quando o cromo (VI) é transportado pela água subterrânea ele pode ser transformado e precipitado como cromo (III), se a água entrar numa zona de baixo potencial redox. Estudos de laboratório têm mostrado que cromo (VI) pode ser reduzido para cromo (III) na presença de matéria orgânica, especialmente em baixo pH (Bartlett \& Kimble, 1976; Bloomfield \& Pruden, 1980 apud Calder, 1988). Schroeder \& Lee (1975 apud Calder, 1988), encontraram que cromo (VI) poderia também ser reduzido para ferro (II) e dissolver sulfetos.

$\mathrm{O}$ cromo (III) geralmente não é transportado à grandes distâncias pela água subterrânea devido à sua baixa solubilidade. Porém, ele poderia ser convertido para cromo (VI), se o estado de redox para um lugar particular for mudando com o tempo, de redutor para oxidante.

\section{Adsorção}

A adsorção ocorre porque as espécies iônicas dissolvidas na água subterrânea são atraídas pelas superficies dos minerais que constituem o aquífero, por possuírem uma rede de carga elétrica, própria para substituições (Freeze and Cherry, 1979).

A adsorção de um contaminante pelos solos ou materiais do aquífero pode retardar o avanço do contaminante em relação à velocidade da água subterrânea. 
Segundo Stumm and Morgan (1981), íons positivamente carregados tais como $\mathrm{Cr}^{3+}$, que é o grau de oxidação de cromo (III) abaixo de um $\mathrm{pH} 4$, são geralmente adsorvidos por minerais de argila. A adsorção de $\mathrm{Cr}^{3+}$ por solos e argilas é geralmente muito alta, aumentando com o $\mathrm{pH}$.

$\mathrm{O}$ cromo (III) é relativamente imóvel para um pH próximo de 4 , devido à adsorção. Acima deste $\mathrm{pH}$ ele é também relativamente imóvel devido a sua baixa solubilidade.

$\mathrm{Na}$ forma aniônica $\mathrm{HCrO}_{4}{ }^{-}$e $\mathrm{CrO}_{4}{ }^{2-}$, o cromo (VI) é atraído pelas superfícies carregadas positivamente tais como ferro, manganês, óxidos e hidróxidos de alumínio. Estas substâncias comumente cobrem os materiais do aquífero.

A adsorção de cromo (VI) por argilas, solos e materiais naturais do aquífero é baixa a moderada nas faixas de $\mathrm{pH}$ que comumente são encontradas nas águas subterrâneas. A adsorção do cromo (VI) decresce com o aumento do pH. Pouca ou nenhuma adsorção ocorre acima de um pH 8,5.

\subsection{FONTES DE POLUIÇÃO}

A presença de cromo nas águas subterrâneas está normalmente associada à contaminação de origem antrópica. No norte dos Estados Unidos e em alguns locais do Japão, a contaminação das águas subterrâneas por este metal é um grande problema. É melhor evidenciada em áreas onde estão instaladas indústrias de metal e de tratamento de madeira, curtumes, mineração de cromo e processos de beneficiamento do metal. Outras fontes de poluição podem ser citadas, como indústrias de manufaturas de pigmentos, de filmes fotográficos, de inibidores de corrosão, entre outras.

Migliorini (1994), no estudo das águas subterrâneas do Cemitério de Vila Formosa, na cidade de São Paulo, encontrou cromo, entre outros metais, em 
concentrações variando de $<0,05$ a $0,17 \mathrm{mg} / \mathrm{l}$. Segundo o autor, o cromo é provavelmente originário das tintas, vernizes e guarnições dos caixões.

A ocorrência natural do elemento em concentrações acima das normas de potabilidade da água é bastante rara. As referências bibliográficas especializadas sobre o assunto são escassas.

Robertson (1975), descreve o caso do Paradise Valley (Arizona, E.U.A.) onde as concentrações de cromo variavam de 0,1 a $2,0 \mathrm{mg} / \mathrm{l}$. Embora o autor não tenha estabelecido a origem primária do cromo, entende-se que este elemento está associado aos minerais de argila, cuja área-fonte não é reconhecida.

Szikszay (1981), no estudo das Fontes de Águas da Prata (S.P.), encontrou teores de cromo total variando de 0,014 a $0,3 \mathrm{mg} / \mathrm{l}$ em águas provenientes de rochas vulcânicas, e valores variando de 0,019 a $0,3 \mathrm{mg} / \mathrm{l}$, nas águas provenientes de arenitos.

Segundo Love (1967), poucas de algumas águas contêm cromo de fontes naturais. Águas naturais podem provavelmente contê-lo somente como elemento traço. Porém, na região de Urânia foi feita uma avaliação preliminar sobre a presença de cromo nas águas subterrâneas e constatou-se que a ocorrência deste elemento é natural (Hirata \& Rodolfi 1993). Este resultado é baseado nas seguintes observações: i) o cromo (VI) ocorre distribuído de forma ampla na região, o que discorda da contaminação antrópica, onde o cromo aparece em áreas restritas, não ultrapassando algumas centenas de metros da fonte de origem; ii) sua maior concentração foi encontrada em poços tubulares de grande profundidade, o que reforça a origem natural, pois se houvesse uma aplicação de cromo em superficie,os poços cacimbas seriam os mais atingidos, iii) não havia nas proximidades dos poços atingidos nenhum indício de atividade contaminante, mesmo no passado. 


\subsection{ASPECTOS DE LEGISLAÇÃO}

$\mathrm{O}$ cromo é um elemento que apresenta toxicologia bastante complexa. $\mathrm{O}$ limite permitido em águas para consumo humano é $0,05 \mathrm{mg} / \mathrm{l}$ para cromo total. Segundo CETESB (1994), este valor está de acordo com os padrões de potabilidade brasileiros ( Portaria 36, do Ministério da Saúde, de 19-01-90), da Organização Mundial de Saúde (OMS), da Comunidade Econômica Européia, Canadá, E.U.A. e Alemanha. No Decreto Estadual 12.486, de 20-10-78 o valor máximo permitido de cromo hexavalente em águas para consumo humano é $0,05 \mathrm{mg} / \mathrm{l}$. 


\section{METODOLOGIA}

Com a finalidade de atingir os objetivos propostos nesta pesquisa, foram efetuadas as seguintes etapas de trabalho:

-Caracterização da ocorrência de cromo nas águas subterrâneas do noroeste do Estado de São Paulo;

-Cadastramento de poços tubulares;

-Avaliação geoquímica das águas, sedimentos e rochas basálticas de Urânia-S.P;

-Levantamento sobre eventuais problemas de saúde da população abastecida por águas subterrâneas com teores de cromo acima do limite de potabilidade.

\subsection{CARACTERIZAÇÃO DA OCORRÊNCIA DE CROMO NAS ÁGUAS SUBTERRÂNEAS DO NOROESTE DO ESTADO DE SÃO PAULO}

\subsubsection{CROMO TOTAL}

A partir dos resultados das análises físico-químicas das águas subterrâneas da SABESP, foi realizado um estudo sobre a ocorrência e distribuição espacial do cromo na região noroeste do Estado de São Paulo. Os dados são de águas de poços de 54 localidades operadas pela empresa, entre municípios e distritos, no período de 1977 a 1993.

Os laudos continham resultados de análises físico-químicas completas, mas para este estudo interessa somente os seguintes parâmetros: cromo total (trivalente + hexavalente) e hexavalente, por serem os principais elementos da pesquisa, 
nitrogênio nitrato e condutividade elétrica, por apresentarem variações em suas concentrações nos diversos poços.

Os teores de cromo total foram plotados na figura 04 para melhor visualização da extensão espacial da anomalia e na tentativa de estabelecer um padrão para a distribuição do cromo na região.

\subsubsection{CROMO HEXAVALENTE}

Nesta fase de identificação de áreas onde ocorre cromo hexavalente nas águas subterrâneas, além dos dados da SABESP, também foi feita a amostragem de água subterrânea em outras 12 localidades, operadas ou não pela SABESP. Estas localidades foram escolhidas para completar os vazios geográficos da área contendo análise de cromo na região.

Durante a amostragem foram medidos em "in situ" os seguintes parâmetros, com os respectivos equipamentos: a temperatura do ar e da água (termômetro), o pH (pHmetro "OAKTON", modelo 35624-00), a condutividade elétrica corrigida para $25^{\circ} \mathrm{C}$ pelo próprio equipamento e os sólidos totais dissolvidos-STD (medidor de condutividade e sólidos totais dissolvidos "HACH", modelo 44600).

O laboratório da SABESP de Fernandópolis analisou as concentrações de cromo hexavalente pelo método difenilcarbazida com o Espectrofotômetro "MICRONAL", modelo B 380, cujo limite de detecção é de $0,0025 \mathrm{mg} / \mathrm{l}$

Os dados com as concentrações de cromo hexavalente também foram plotados na figura 04. Para uma melhor visualização das variações dos teores de cromo hexavalente com o $\mathrm{pH}$, condutividade elétrica e sólidos totais dissolvidos foram confeccionados os gráficos $1 \mathrm{~A}, 1 \mathrm{~B}$ e $1 \mathrm{C}$. 
A partir destas análises escolheu-se três poços em Urânia e um em Santa Salete para coleta de água em poços selecionados, por apresentarem as maiores concentrações de cromo hexavalente.

\subsubsection{CROMO TOTAL, HEXAVALENTE E NITROGÊNIO NITRATO NAS ÁGUAS SUBTERRÂNEAS DE URÂNIA}

As águas subterrâneas da cidade de Urânia foram selecionadas para um estudo dos teores de cromo total, hexavalente e nitrogênio nitrato.

Este estudo foi desenvolvido a partir dos resultados das análises físicoquímicas das águas subterrâneas realizadas pela SABESP, no período de 1977 a 1993.

Foi efetuado um levantamento das concentrações de cromo total, hexavalente e nitrogênio nitrato em seis poços da cidade de Urânia (P 1, P 2, P 3, P 4, P 5, P 6). Para uma melhor visualização do comportamento destes parâmetros, os dados foram plotados em gráficos que apresentam os valores de suas concentrações com a data de coleta (gráficos 2A, 2B, 3A, 3B, 4A, 4B, 5A, 5B, 6A, 6B, 7A, 7B).

\subsubsection{CROMO TOTAL E HEXAVALENTE EM POÇOS SELECIONADOS DE URÂNIA E SANTA SALETE}

Foram escolhidos quatro poços para coleta e análise das águas subterrâneas das áreas de estudo de detalhe. Três dos poços localizam-se em Urânia (P 2, P 4, $P$ 5) e um em Santa Salete (P 1).Estes poços foram selecionados por apresentarem as maiores concentrações de cromo hexavalente $(0,08-0,10 \mathrm{mg} / \mathrm{l})$. 
As amostras das águas subterrâneas foram coletadas diretamente das bocas dos poços que já estavam sendo bombeados a mais de uma hora, sem interrupção. No instante da coleta foram medidos os seguintes parâmetros, com os mesmos equipamentos citados no ítem 4.1.2.: temperatura do ar e da água, pH, Eh (Ehmetro "OAKTON", modelo 35650-00), condutividade elétrica e sólidos totais dissolvidos (STD).

A análise da água inclui cromo total, hexavalente e ainda alguns outros parâmetros, como sulfato, bicarbonato, nitrogênio nitrato, fluoreto, sódio, potássio, ferro total, manganês, alumínio, sílica, Resíduo Seco a $180^{\circ} \mathrm{C}$.

As recomendações seguidas para coleta e preservação das amostras encontram-se reunidas no "Guia Técnico de Coleta de Amostras da CETESB", segundo Souza \& Derisio (1977).

As análises da água dos quatro poços foram efetuadas pelos laboratórios da SABESP de Fernandópolis e Lins, sendo que os parâmetros sódio, potássio, sílica e Resíduo Seco a $180^{\circ} \mathrm{C}$ da primeira coleta e sódio da terceira coleta, foram analisados pela Companhia de Tecnologia de Saneamento Ambiental (CETESB) em São Paulo.

As amostras de água encaminhadas aos laboratórios da SABESP para análises físico-químicas, foram coletadas em frascos de vidro (cromo total e hexavalente, sulfato, nitrogênio nitrato, ferro total, manganês e alumínio) e de polietileno (fluoreto, potássio e sílica). A preservação das amostras foi realizada da seguinte forma: cromo total, potássio, ferro total e manganês com $\mathrm{HNO}_{3}$ e $\mathrm{pH}<2$; sulfato com $2 \mathrm{ml}$ de acetato de zinco ( $\mathrm{pH}$ 6-9); nitrogênio nitrato com $\mathrm{H}_{2} \mathrm{SO}_{4}, \mathrm{pH}<2$ e refrigeradas a $4^{\circ} \mathrm{C}$; fluoreto e sílica refrigeradas a $4^{\circ} \mathrm{C}$.

Os métodos de análises químicas utilizados nos laboratórios da SABESP para os respectivos parâmetros físico-químicos são os seguintes: cromo total, potássio (colorimétrico), cromo hexavalente (difenilcarbazida), sulfato (turbidimétrico), 
fluoreto (eletrodo de íons seletivo), ferro total (ortofenantrolina), manganês (persulfato), alumínio (eriocromoclanina).

Os equipamentos utilizados pela SABESP para análise dos parâmetros físicoquímicos foram: cromo total, nitrogênio nitrato, potássio, sílica (Espectrofotômetro "HACH", modelo DR-2000), cromo hexavalente, ferro total, manganês, alumínio (Espectrofotômetro "MICRONAL", modelo B 380), sulfato (Turbidímetro "MICRONAL", modelo 250), bicarbonato (pHmetro "PROCYON", modelo pHD 210), fluoreto (Fluorímetro "PROCYON", modelo $710 \mathrm{~A}$ ).

As amostras destinadas aos laboratórios da CETESB para análises físicoquímicas, foram coletadas em frascos de polietileno, novos e descartáveis, refrigerados a $4^{\circ} \mathrm{C}$, com gelo, em caixa de isopor, sem preservativo para análise de sílica e Resíduo Seco a $180^{\circ} \mathrm{C}$; as amostras para análise de sódio e potássio foram preservadas com $\mathrm{HNO}_{3}(\mathrm{pH}<2)$.

Os métodos de análises químicas aplicados nos laboratórios da CETESB são baseados na 17A edição do "Standard Methods for the Examination of Water and Wastewater-American Public Health Association-USA". Para determinação dos parâmetros físico-químicos das águas subterrâneas a $25^{\circ} \mathrm{C}$, foram: Resíduo Seco a $180^{\circ} \mathrm{C}$ (gravimétrico), sílica (colorimétrico com molibidato de amônia), sódio e potássio (absorção atômica).

Os limites de deteç̧ão (LD) para cada um dos parâmetros analisados, em $\mathrm{mg} / \mathrm{l}$ são: Resíduo Seco a $180^{\circ} \mathrm{C}$ (não existe um limite estabelecido; sílica ( $\mathrm{LD}=0,6$ $\mathrm{mg} / \mathrm{l})$; sódio $(\mathrm{LD}=0,01 \mathrm{mg} / \mathrm{l})$; potássio $(\mathrm{LD}=0,02 \mathrm{mg} / \mathrm{l})$.

Foram realizadas duas coletas num intervalo de 22 dias e ainda um terceira para verificar se existiam variações temporais nos parâmetros analisados.Estes parâmetros encontram-se na tabela 04 . Foram confeccionados gráficos com as variações de cromo total e cromo hexavalente com o tempo (gráficos $8 \mathrm{~A}, 8 \mathrm{~B}$ ). 


\subsubsection{CROMO TOTAL EM POÇOS PERFURADOS APENAS NO GRUPO BAURU OU EM POÇOS COM ENTRADAS DE ÁGUA APENAS NA FORMAÇÃO SERRA GERAL}

Através do cadastramento de poços (anexo 01), foram selecionados aqueles perfurados apenas nos sedimentos da Formação Adamantina do Grupo Bauru e aqueles que possuem entradas de água apenas nos basaltos da Formação Serra Geral. Foi confeccionada uma tabela com as cidades onde se localizam estes poços, os números dos poços e as concentrações de cromo total com a data de coleta (tabela 05).

A partir desta tabela foram definidas se as maiores concentrações de cromo total estavam em águas do Sistema Aquífero Bauru (sedimentos) ou do Sistema Aquífero Serra Geral (basaltos).

\subsection{CADASTRAMENTO DE POÇOS TUBULARES}

Para o estudo hidrogeológico foi efetuado um cadastro de poços tubulares. Os poços são das localidades onde a SABESP já havia realizado análises físicoquímicas da água. Os dados foram obtidos na SABESP de São Paulo.

Do cadastro consta a localidade onde foi executada a amostragem (município ou distrito), o número do poço local, o número do poço dado pela SABESP e pelo Departamento de Águas e Energia Elétrica (DAEE), suas coordenadas, cota topográfica, profundidade, níveis estático e dinâmico, vazão, geologia, posição dos filtros, cimentação, ano de perfuração, uso da água, firma perfuradora e a referência do local de perfuração (anexo 01). A falta de um ou outro dado no cadastro é devido a não existência deste na sua ficha da SABESP. 
Nas doze localidades onde foi realizada a amostragem citada no ítem 4.1.2 não se tem o cadastro de todos os poços. Apenas os poços de Aspásia, Urânia e Santa Salete foram cadastrados por serem operadas pela SABESP. Tentou-se cadastrar as outras localidades através do DAEE, porém os dados que lá se encontram estão em fichas antigas, não sendo suficientes e nem confiáveis.

\subsection{AVALIAÇÃo GeOQUímiCA DAS ÁGUAS, SEDIMENTOS E ROCHAS BASÁLTICAS DE URÂNIA-S.P.}

Os pontos onde foram coletadas amostras de águas, sedimentos e rochas, encontram-se na figura 06.

\subsubsection{ANÁLISES DE ÁGUAS}

Durante a perfuração de um poço em Urânia (P 9), próximo ao Córrego Comprido, coletou-se amostras de água em três profundidades diferentes $(114,180$ $182,270 \mathrm{~m}$ ), para análise de cromo total. Durante a coleta foram medidos em campo, com os mesmos equipamentos citados no ítem 4.1.2, a temperatura do ar, da água, $\mathrm{pH}$, condutividade elétrica, sólidos totais dissolvidos (STD). A 270 metros de profundidade, foram analisados os teores de cloreto, sulfato, cálcio, magnésio, ferro total e alumínio.Estas análises foram feitas pelo laboratório da SABESP de Fernandópolis.

As amostras de água para análise de cromo total, sulfato, ferro total e alumínio foram coletadas, preservadas e analisadas pelos mesmos métodos e equipamentos citados no ítem 4.1.4. 
As amostras de água para análise de cloreto, cálcio e magnésio foram coletadas em frascos de vidro. A preservação das amostras de cálcio e magnésio foi realizada com $\mathrm{HNO}_{3}$ e $\mathrm{pH}<2$.

Foram feitas coletas de água em dois poços, um na Fazenda Jatobá e o outro no Posto de Gasolina Garção, ambos no município de Urânia. Estes poços atingem somente os sedimentos da Formação Adamantina. Foram analisados os mesmos parâmetros anteriormente citados e comparadas as concentrações de cromo total.

Foram também analisados os teores de cromo total e hexavalente em duas amostras do Córrego Comprido, para uma comparação das concentrações de cromo nas águas subterrâneas e superficiais.

\subsubsection{ANÁLISE DOS SEDIMENTOS DE URÂNIA E DO POÇO P 9}

Para estudar a ocorrência de cromo nos sedimentos foram analisadas duas amostras que afloram em Urânia. Coletou-se também três amostras de sedimentos do poço $P 9$ durante a sua perfuração.

Estas amostras foram secadas e moídas em um moinho de bolas de carbeto de tungstênio, no laboratório do CPGEO (Centro de Pesquisas Geocronológicas) do Instituto de Geociências da USP (IGc/USP).

A abertura das amostras foi feita nos laboratórios do Departamento de Mineralogia e Petrologia do IGc/USP (DMP/USP), onde foi utilizado o seguinte procedimento:

- quantidade de amostra: 0,2500 g;

- quantidade e tipo de fundente: $0,7500 \mathrm{~g}$ (meta e tetraborato de lítio);

- tempo e temperatura de fusão: 20 minutos, $1000^{\circ} \mathrm{C}$;

- volume final da solução: $250 \mathrm{ml}$;

- concentração da amostra: $1000 \mathrm{mg} / \mathrm{l}$; 
- meio: $\mathrm{HNO}_{3}$ 0,2 N.

Foram analisados os elementos zinco, cromo, cobre, zircônio e ítrio pelo ICPAES (Plasma) do DMP. As concentrações destes elementos nos sedimentos de Urânia foram comparadas com as médias encontradas em sedimentos equivalentes da crosta terrestre.

\subsubsection{ANÁLISE DOS BASALTOS DO POÇO P 9}

Foram escolhidas para análise onze amostras de calha de rochas basálticas do poço $P 9$, de profundidades diferentes $(70,90,110,130,150,170,190,210,230$, $250,270 \mathrm{~m}$ ), de tal forma que fossem representativas no perfil geológico do poço (Figura 05).

Inicialmente os fragmentos das amostras foram lavados para remoção de material argiloso. A lavagem e secagem foram feitas no laboratório do CPGEO (Centro de Pesquisas Geocronológicas).

Estas amostras foram descritas no laboratório do DMP utilizando-se uma lupa binocular, sendo removidos os fragmentos de vesículas (contendo calcita ou alguma outra heterogeneidade) com uma pinça .

Após a descrição, foram moídas 50 gramas de cada amostra no moinho de carbeto de tungstênio do laboratório do CPGEO.

Terminando esta etapa, iniciaram-se as aberturas das amostras nos laboratórios do DMP, seguindo o mesmo procedimento adotado para as amostras de sedimentos.

Nas amostras de basaltos foram analisadas as concentrações de $\mathrm{SiO}_{2}, \mathrm{Al}_{2} \mathrm{O}_{3}$, $\mathrm{Fe}_{2} \mathrm{O}_{3}, \mathrm{MgO}, \mathrm{CaO}, \mathrm{Na}_{2} \mathrm{O}, \mathrm{K}_{2} \mathrm{O}, \mathrm{TiO}_{2}, \mathrm{P}_{2} \mathrm{O}_{5}, \mathrm{MnO}, \mathrm{Cr}, \mathrm{Ni}, \mathrm{V}, \mathrm{Ba}$, Sr, pelo ICP-AES (Plasma) do DMP. As concentrações de alguns elementos traços também foram comparadas com as médias encontradas nos basaltos da crosta terrestre. 


\subsection{LEVANTAMENTO SOBRE EVENTUAIS PROBLEMAS DE SAÚDE DA POPULAÇÃO ABASTECIDA POR ÁGUAS SUBTERRÂNEAS COM TEORES DE CROMO ACIMA DO LIMITE DE POTABILIDADE}

O levantamento sobre a saúde da população de Urânia foi realizado através de contatos com o Escritório Regional de Saúde de Jales (ERSA) e com o Centro de Saúde de Urânia.

Foram consultadas pessoas diretamente ligadas a estes órgãos, para se obter informações sobre a existência de estudos realizados na região, que pudessem comprovar doenças causadas pela ingestão de água contendo teores de cromo acima do limite permissível. 


\section{APRESENTAÇÃO DOS RESULTADOS}

\subsection{CARACTERIZAÇÃO DA OCORRÊNCIA DE CROMO NAS ÁGUAS SUBTERRÂNEAS DO NOROESTE DO ESTADO DE SÃO PAULO}

\subsubsection{CROMO TOTAL}

Os parâmetros cromo total, cromo hexavalente, nitrogênio nitrato $\mathrm{e}$ condutividade elétrica foram colocados no anexo 02 . Neste anexo encontram-se as localidades onde foram feitas as coletas de água, o número do poço local, o número do poço dado pela SABESP, a data de coleta, as concentrações de cromo total, cromo hexavalente, nitrogênio nitrato e condutividade elétrica. Através deste anexo é possível observar que as concentrações dos parâmetros citados variam com a data de coleta num mesmo poço e, também, de poço para poço, numa mesma localidade.

Os pontos onde ocorrem concentrações de cromo total, abaixo ou acima do limite de potabilidade foram plotados em um mapa (Figura 04). É importante ressaltar que estes pontos, por questão de escala, não correspondem às localizações dos poços, e sim, às análises feitas das águas de um ou mais poços da mesma localidade.

Pela figura 04 nota-se que o cromo total encontra-se distribuído por vários municípios e distritos do noroeste paulista. Em alguns locais suas concentrações são menores ou iguais ao limite de potabilidade $(\leq 0,05 \mathrm{mg} / \mathrm{l})$. Em outros, estão acima deste limite $(>0,05 \mathrm{mg} / \mathrm{l})$. Há ainda localidades em que as concentrações de cromo total nas águas subterrâneas variam abaixo e acima deste limite $(0,005-0,155 \mathrm{mg} / \mathrm{l})$.

A seguir serão descritas as localidades com concentrações de cromo total menores ou iguais a $0,05 \mathrm{mg} / \mathrm{l}$, acima de $0,05 \mathrm{mg} / \mathrm{l} \mathrm{e}$ variando de $0,005-0,155 \mathrm{mg} / \mathrm{l} \mathrm{e}$ os respectivos anos de coleta. Estas coletas foram feitas em um ou mais poços de 


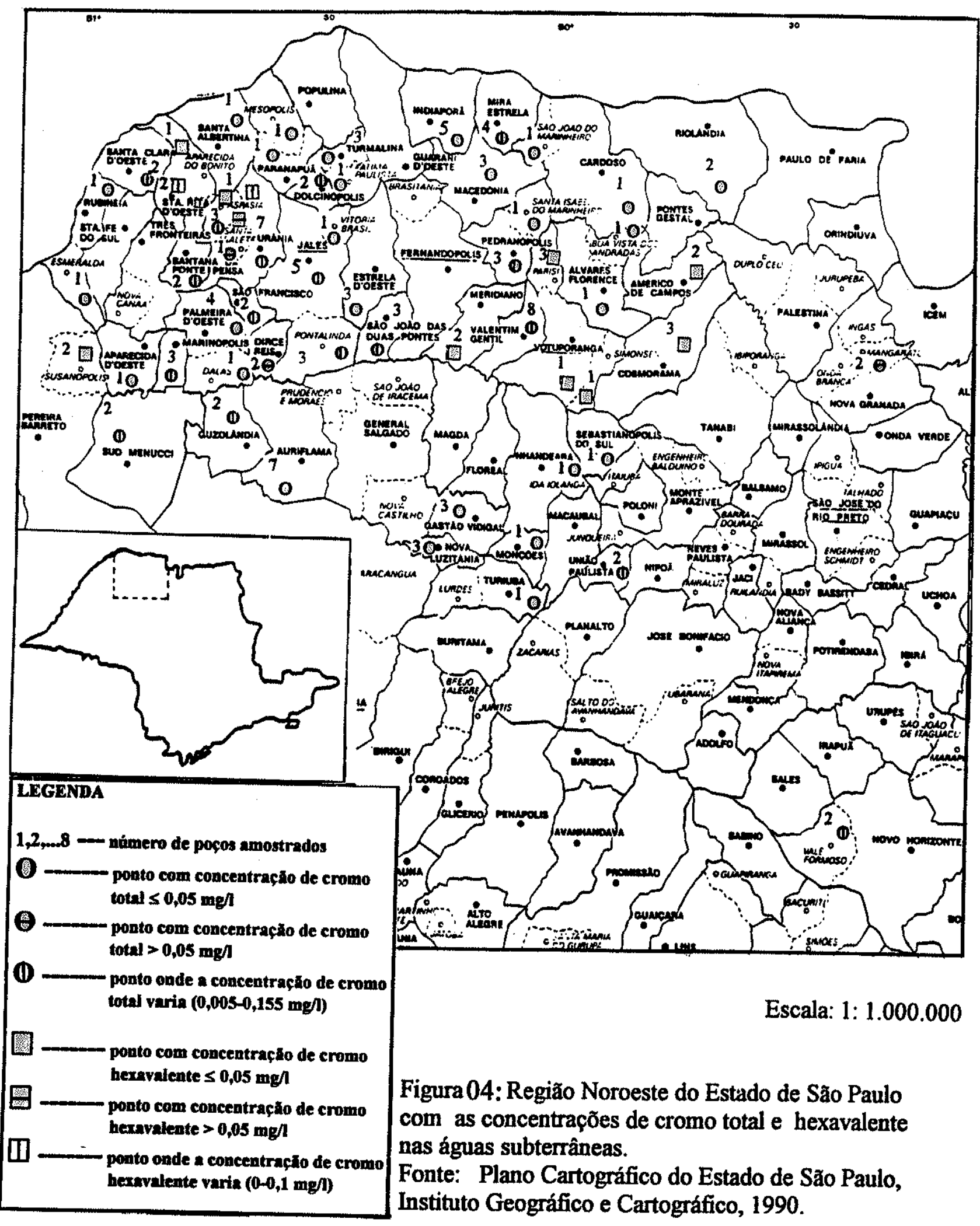


cada localidade.

\section{Localidades com concentrações de cromo total $\leq \mathbf{0 , 0 5} \mathbf{~ m g / l}$}

Álvares Florence (82/88), Aparecida D' Oeste (87/88/89), Arabá (80), Auriflama (81/82/84/88/89), Boa Vista dos Andradas (82/87/89), Cardoso (89), Dalas (80), Dulcelina (86/87/88/89), Esmeralda (81/87/88/89), Estrela D' Oeste (81), Fátima Paulista (93), Gastão Vidigal (80/84), Ida Iolanda (79), Indiaporã (80/87/88/93), Macedônia (81/84/87/88), Mesópolis (80), Monções (87/88), Nova Lusitânia (83/88/91), Palmeira D' Oeste (79/90), Paranapuã (79), Riolândia (85/86), Rubinéia (80/87/88/89), Santa Albertina (87/88/89), Santa Isabel do Marinheiro (80), São João do Marinheiro (79), Sebastianópolis do Sul (85), Socimbra (85), Tupinambá (87/88), Turiuba (84), Turmalina (81/87/88/89), Vila Alves (79), Vitória Brasil (79).

\section{Localidades com concentrações de cromo total $>0,05 \mathrm{mg} / \mathrm{l}$}

Dirce Reis (93), Mangaratu (82/83), Santa Salete (90/93).

Localidades onde as concentrações de cromo total variam de 0,005 a $0,155 \mathrm{mg} / \mathrm{l}$

Aspásia (80/81/83/87/88/89/90), Bandeirante D' Oeste (85/93), Dolcinópolis (87/88/89/92/93), Guzolândia (85/88/93), Jales (80/87/88/92/93), Marinópolis (89/91/92/93), Mira Estrela (80/81/84/87/88), Pedranópolis (81/84/86/87/89), Pontalinda (79/80/87), Santa Clara D' Oeste (82/87/88/89), Santana da Ponte Pensa (79/87/88/89/90), São Francisco (87/88/90/93), São João das Duas Pontes (84/87/93), Sud Mennucci (81/88/91/93), União Paulista (89), Urânia (77/78/79/80/81/82/83/84/87/88/89/90/92/93). 
A partir destes resultados é possível observar que a anomalia de cromo encontra-se distribuída por uma ampla região, apresenta-se de forma irregular, tanto temporal quanto espacialmente.

\subsubsection{CROMO HEXAVALENTE}

Os resultados das análises físico-químicas das águas subterrâneas das doze localidades do noroeste paulista encontram-se na tabela 03. Esta tabela apresenta as localidades onde foram coletadas as amostras de água, os poços, as datas de coleta, as concentrações de cromo hexavalente, temperaturas do ar e da água, $\mathrm{pH}$, condutividade elétrica e sólidos totais dissolvidos (STD).

Nestas doze localidades, os parâmetros acima citados apresentam as seguintes variações: cromo hexavalente: $<0,0025-0,10 \mathrm{mg} /$; t temperatura do ar: 25 $36{ }^{\circ} \mathrm{C}$; temperatura da água: $23-29{ }^{\circ} \mathrm{C}, \mathrm{pH}$ : 6,3-9,8 (nos poços tubulares); condutividade elétrica: $128-440 \mu \mathrm{S} / \mathrm{cm}$ à $25^{\circ} \mathrm{C}$; sólidos totais dissolvidos: $64-220$ $\mathrm{mg} / \mathrm{l}$.As variações dos teores de cromo hexavalente com o $\mathrm{pH}$, condutividade elétrica e sólidos totais dissolvidos podem ser vistas nos gráficos $1 \mathrm{~A}, 1 \mathrm{~B}$ e 1C.Estes gráficos mostram um comportamento irregular entre os parâmetros anteriormente citados, não permitindo estabelecer uma relação entre eles. O gráfico $1 \mathrm{~A}$, no entanto, mostra que os teores de cromo apresentam uma tendência a aumentar com o $\mathrm{pH}$.

Pela tabela 03, nota-se que as concentrações de cromo hexavalente na maioria das localidades estão abaixo ou no limite de potabilidade $(\leq 0,05 \mathrm{mg} / \mathrm{l})$ : Américo de Campos, Aparecida do Bonito, Aspásia, Cosmorama, Meridiano, Parisi, Simonsen, Suzanápolis Votuporanga. Santa Salete porém, apresenta uma concentração de cromo hexavalente acima do limite de potabilidade $(>0,05 \mathrm{mg} / \mathrm{l})$. Em Santa Rita D'Oeste e Urânia as concentrações de cromo hexavalente variam 
acima e abaixo de $0,05 \mathrm{mg} / \mathrm{l}$, dependendo do poço.Os pontos onde ocorrem concentrações de cromo hexavalente também foram plotados no mapa da figura 04.

Pela tabela 03 e figura 04, é possível observar que as concentrações de cromo hexavalente variam de localidade para localidade e também nos poços de uma mesma localidade, mostrando uma distribuição espacial irregular.

Não foi possível obtever um padrão que pudesse explicar esta distribuição irregular (tempo e espaço) das concentrações de cromo total e hexavalente.

Tabela 03: Resultados das análises físico-químicas das águas subterrâneas das 12 localidades do noroeste paulista.

\begin{tabular}{|c|c|c|c|c|c|c|c|c|}
\hline Localidade & Poço & $\begin{array}{l}\text { Data de } \\
\text { coleta }\end{array}$ & $\begin{array}{l}\text { Cromo hex. } \\
\text { (mg/l) }\end{array}$ & $\left(\begin{array}{l}T \\
\left.{ }^{\circ} \mathrm{C}\right)\end{array}\right.$ & $\begin{array}{l}T \text { água } \\
\left({ }^{\circ} \mathrm{C}\right)\end{array}$ & $\mathrm{pH}$ & $\begin{array}{l}\text { Condut. } \\
\text { eletrica } \\
(\mu \mathrm{S} / \mathrm{cm}) \mathrm{a} \\
25^{\circ} \mathrm{C}\end{array}$ & $\begin{array}{l}\text { STD } \\
(\mathrm{mg} / \mathrm{l})\end{array}$ \\
\hline \multirow[t]{2}{*}{ 1-Américo de Campos } & P1 & $08 / 12 / 94$ & 0,01 & 30 & 28 & 9,6 & 260 & 130 \\
\hline & P 2 & $08 / 12 / 94$ & 0,03 & 32 & 27 & 7,6 & 188 & 94 \\
\hline $\begin{array}{l}\text { 2-Aparecida do Bonito } \\
\text { (dist. Sta. Rita D'Oeste) }\end{array}$ & $\begin{array}{l}\text { Poço } \\
\text { cacimba }\end{array}$ & $07 / 12 / 94$ & $<0,0025$ & 28 & 26 & 5,3 & 132 & 66 \\
\hline 3-Aspásia & P 3 & $09 / 12 / 94$ & 0,05 & 32 & 27 & 7,8 & 290 & 140 \\
\hline \multirow[t]{3}{*}{ 4-Cosmorama } & $\mathrm{P1}$ & $08 / 12 / 94$ & 0,02 & 31 & 26 & 7,1 & 260 & 140 \\
\hline & P 2 & $08 / 12 / 94$ & 0,04 & 32 & 27 & 6,8 & 220 & 110 \\
\hline & P 4 & $08 / 12 / 94$ & 0,05 & 30 & 26 & 7,9 & 180 & 90 \\
\hline \multirow[t]{2}{*}{ 5-Meridlano } & P1 & $08 / 12 / 94$ & 0,04 & 28 & 25 & 7,9 & 180 & 91 \\
\hline & P 2 & $08 / 12 / 94$ & 0,04 & 28 & 25 & 6,9 & 250 & 130 \\
\hline \multirow[t]{3}{*}{ 6-Parisi } & $P 1$ & $08 / 12 / 94$ & 0,02 & 36 & 28 & 6,7 & 160 & 80 \\
\hline & P 2 & $08 / 12 / 94$ & 0,01 & 36 & 29 & 6,3 & 160 & 80 \\
\hline & P 3 & $08 / 12 / 94$ & 0,02 & 36 & 28 & 6,6 & 260 & 130 \\
\hline \multirow[t]{2}{*}{ 7-Santa Rita D' Oeste } & P1 & $07 / 12 / 94$ & 0,03 & 29 & 27 & 9,5 & 260 & 130 \\
\hline & P 2 & $07 / 12 / 94$ & 0,08 & 29 & 28 & 9,8 & 300 & 155 \\
\hline $\begin{array}{l}\text { 8-Santa Salete (dlst. de } \\
\text { Urania) }\end{array}$ & P1 & $09 / 12 / 94$ & 0,10 & 32 & 27 & 9,1 & 175 & 88 \\
\hline $\begin{array}{l}\text { 9-Simonsen (dist. de } \\
\text { Votuporanga) }\end{array}$ & $\longdiv { P 1 }$ & $08 / 12 / 94$ & 0,05 & 34 & 28 & 7,6 & 230 & 120 \\
\hline \multirow[t]{2}{*}{ 10-Suzanápolis } & P1 & $07 / 12 / 94$ & 0,02 & 30 & 26 & 6,6 & 137 & 79 \\
\hline & P 4 & $07 / 12 / 94$ & 0,02 & 27 & 23 & 7,7 & 210 & 110 \\
\hline \multirow[t]{6}{*}{ 11-Urânia } & $P 1$ & $09 / 12 / 94$ & 0,03 & 29 & 27 & 7,3 & 147 & 70 \\
\hline & P 2 & $09 / 12 / 94$ & 0,08 & 29 & 28 & 8,5 & 157 & 79 \\
\hline & P 4 & $09 / 12 / 94$ & 0,08 & 32 & 28 & 8,7 & 158 & 79 \\
\hline & P 5 & $07 / 12 / 94$ & 0,08 & 30 & 23 & 8,8 & 152 & 76 \\
\hline & P 6 & $07 / 12 / 94$ & 0,04 & 25 & 26 & 7,4 & 153 & 76 \\
\hline & P 8 & $07 / 12 / 94$ & 0,08 & 26 & 26 & 7,9 & 128 & 64 \\
\hline 12-Votuporanga & $P 1$ & $08 / 12 / 94$ & $<0,0025$ & $\longdiv { 3 4 }$ & $35^{\star}$ & 9,2 & 440 & 220 \\
\hline
\end{tabular}

* = temperatura da água resfriada 


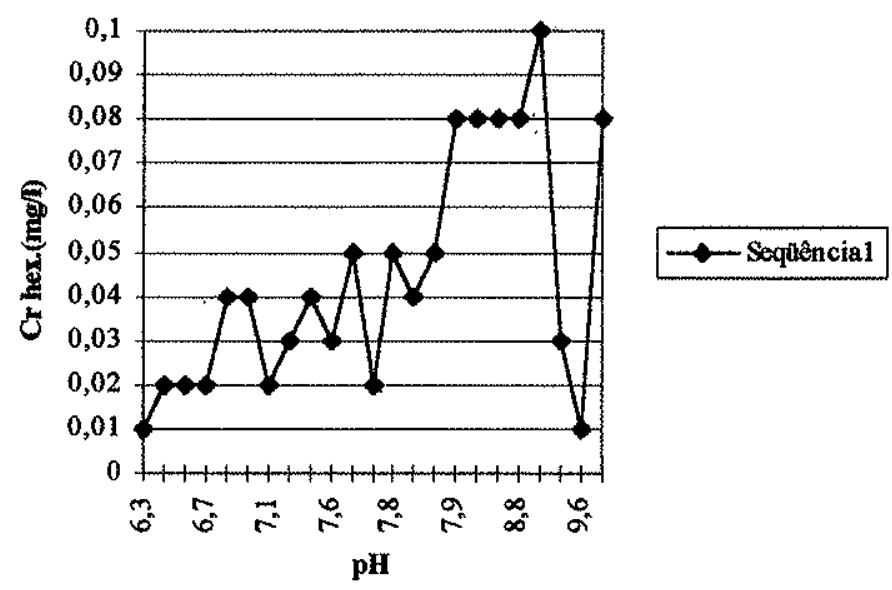

Gráfico 1A: Variação dos teores de cromo hexavalente (mg/l) com o pH.

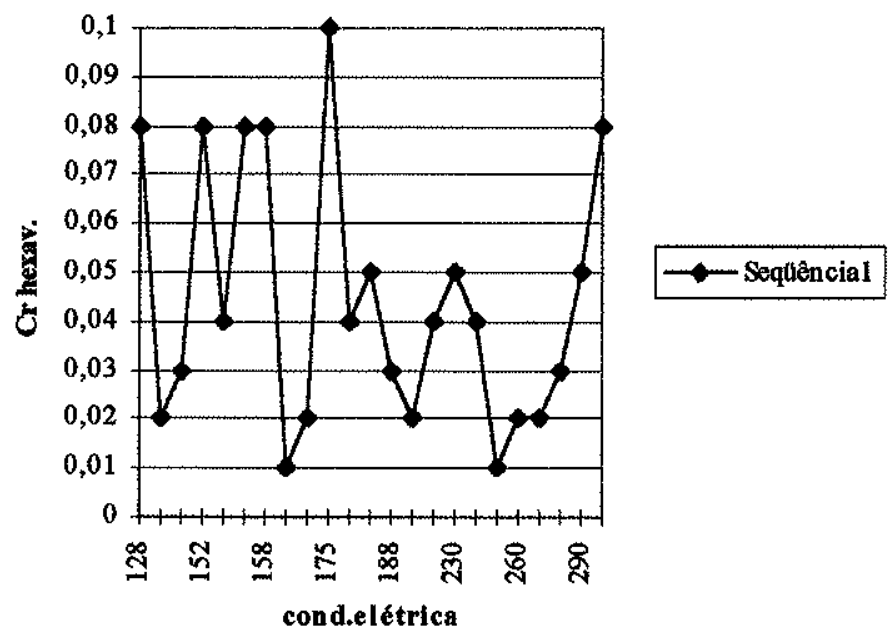

Gráfico 1B: Variação dos teores de cromo hexavalente $(\mathrm{mg} / \mathrm{l})$ com a condutividade elétrica $(\mu \mathrm{S} / \mathrm{cm})$. 


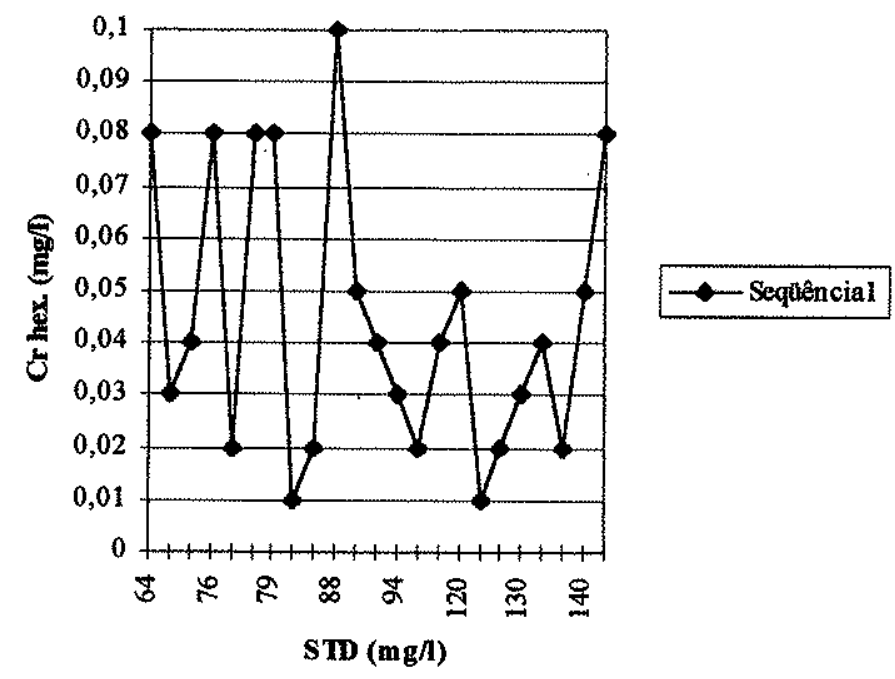

Gráfico 1C: Variação dos teores de cromo hexavalente (mg/l) com os sólidos totais dissolvidos (mg/l).

\subsubsection{CROMO TOTAL, HEXAVALENTE E NITROGÊNIO NITRATO NAS ÁGUAS SUBTERRÂNEAS DE URÂNIA}

As concentrações de cromo total, cromo hexavalente e nitrogênio nitrato dos seis poços da cidade de Urânia (P 1, P 2, P 3, P 4, P 5, P 6), serão descritas a seguir, juntamente com as datas das coletas.Os dados foram plotados em gráficos que apresentam os valores das concentrações destes parâmetros com o tempo.

\section{Poço 1}

O gráfico $2 \mathrm{~A}$ apresenta os valores das concentrações de cromo total variando de 0,023 a $0,122 \mathrm{mg} / \mathrm{l}$, num período de coleta de água que vai de 24/08/77 a 20/08/90.

No gráfico 2B estão as concentrações de cromo total $(0,023-0,068 \mathrm{mg} / \mathrm{l})$, hexavalente $(0,023-0,068 \mathrm{mg} / \mathrm{l})$ e nitrogênio nitrato $(0,6-1,1 \mathrm{mg} / \mathrm{l})$, variando com a data de coleta $(18 / 03 / 81-26 / 06 / 87)$. 


\section{Poço 2}

No gráfico $3 \mathrm{~A}$ estão as concentrações de cromo total $(\mathrm{mg} / \mathrm{l})$ variando de 0,04 a $0,155 \mathrm{mg} / \mathrm{l}$, num período de 24/08/77 a 01/12/93.

O gráfico 3B apresenta as concentrações de cromo total $(0,155-0,073 \mathrm{mg} / \mathrm{l})$, hexavalente $(0,073-0,06 \mathrm{mg} / \mathrm{l})$ e nitrogênio nitrato $(0,71-1 \mathrm{mg} / \mathrm{l})$, variando com a data de coleta $(16 / 10 / 84-26 / 06 / 87)$.

\section{Poço 3}

No gráfico $4 \mathrm{~A}$ encontram-se as concentrações de cromo total $(\mathrm{mg} / \mathrm{l})$ variando de 0,011 a 0,043 mg/l num período de 24/08/77 a 20/08/90.

$\mathrm{O}$ gráfico $4 \mathrm{~B}$ apresenta as concentrações de cromo total $(0,035-0,024 \mathrm{mg} / 1)$, hexavalente $(0,012-0,024 \mathrm{mg} / \mathrm{l})$ e nitrogênio nitrato $(3,7-3,9 \mathrm{mg} / \mathrm{l})$, variando com a data de coleta $(16 / 10 / 84-26 / 06 / 87)$.

\section{Poço 4}

No gráfico $5 \mathrm{~A}$ estão as concentrações de cromo total $(\mathrm{mg} / \mathrm{l})$ variando de 0,05 a $0,11 \mathrm{mg} / \mathrm{l}$ num período de 24/08/77 a 01/12/93.

No gráfico $5 \mathrm{~B}$ encontram-se as concentrações de cromo total $(0,09-0,11$ $\mathrm{mg} / \mathrm{l})$, hexavalente $(0,036-0,11 \mathrm{mg} / \mathrm{l})$ e nitrogênio nitrato $(0,12-0,09 \mathrm{mg} / \mathrm{l})$, variando com a data de coleta $(16 / 10 / 84-26 / 06 / 87)$.

\section{Poço 5}

No gráfico $6 \mathrm{~A}$ encontram-se as concentrações de cromo total $(\mathrm{mg} / \mathrm{l})$ variando de 0,052 a $0,11 \mathrm{mg} / 1$ num período de 26/05/81 a 01/12/93.

O gráfico $6 \mathrm{~B}$ apresenta as concentrações de cromo total $(0,11-0,108 \mathrm{mg} / \mathrm{l})$, hexavalente $(0,08-0,108 \mathrm{mg} / \mathrm{l})$ e nitrogênio nitrato $(0,08-0,07 \mathrm{mg} / \mathrm{l})$, variando com a data de coleta $(16 / 10 / 84-26 / 06 / 87)$. 


\section{Poço 6}

O gráfico 7A apresenta os valores das concentrações de cromo total variando de 0,012 a $0,107 \mathrm{mg} / \mathrm{l}$, num período de 13/04/83 a 01/12/93.

No gráfico 7B estão as concentrações de cromo total $(0,054-0,012 \mathrm{mg} / \mathrm{l})$, hexavalente $(0,036-0,012 \mathrm{mg} / \mathrm{l})$ e nitrogênio nitrato $(1,7-5,1 \mathrm{mg} / \mathrm{l})$, variando com a data de coleta $(16 / 10 / 84-26 / 06 / 87)$.

Pelos gráficos a seguir, nota-se que as concentrações de cromo total, hexavalente e nitrogênio nitrato apresentam uma distribuição irregular em relação à data de coleta das amostras de água.Não foi possível definir uma relação entre estes parâmetros. 


\section{Urånia P 1}

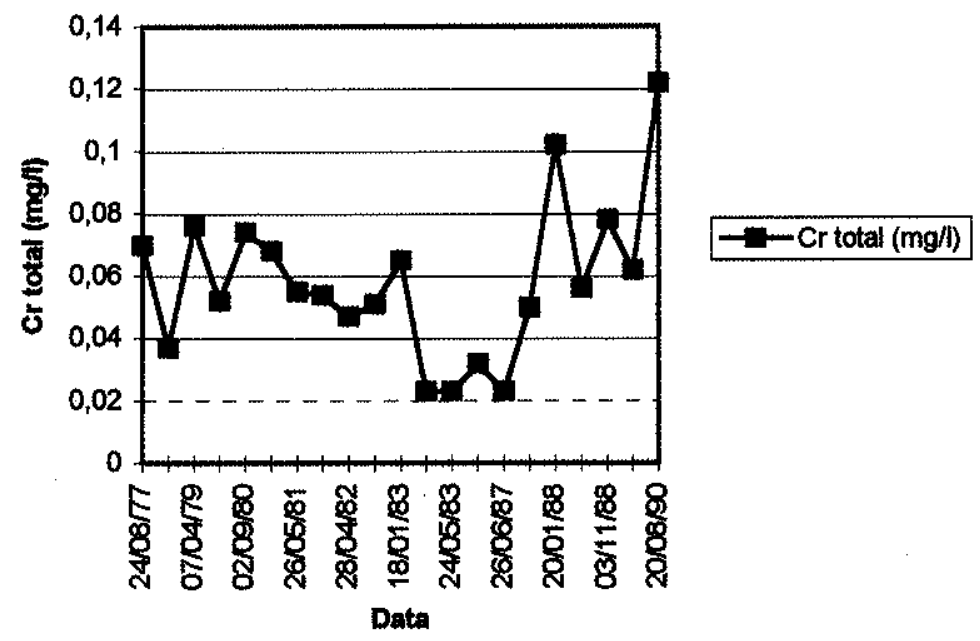

Gráfico 2A: Concentraçôes de cromo total (mg/l) com a data de coleta do poço 1 em Urânia.

\section{Urânia P 1}

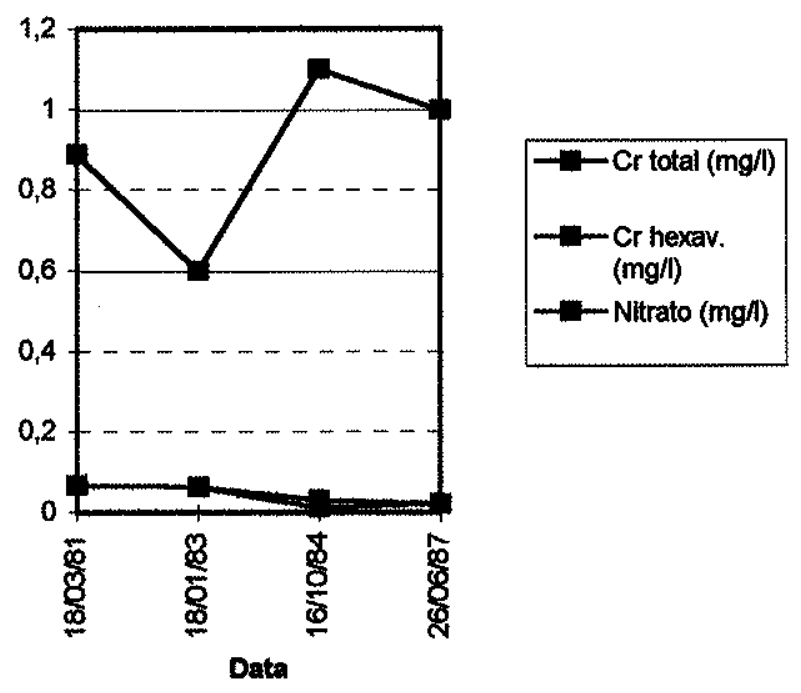

Gráfico 2B: Concentraç̃es de cromo total, hexavalente e nitrogênio nitrato com a data de coleta do poço $1 \mathrm{em}$ Urânia 
Urânia P 2

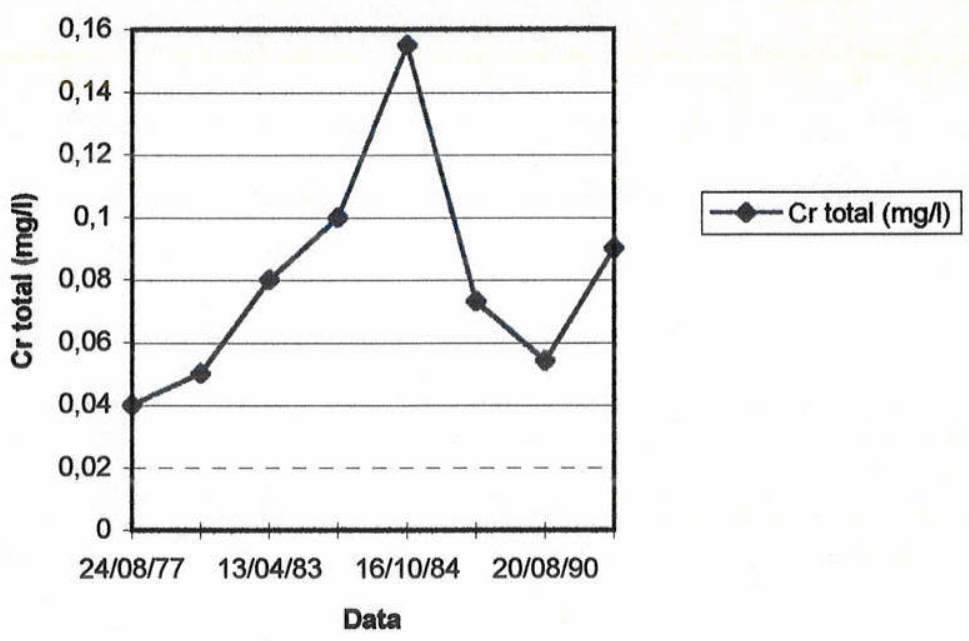

Gráfico 3A: Concentrações de cromo total (mg/l) com a data de coleta no poço 2 em Urânia.

Urânia P 2

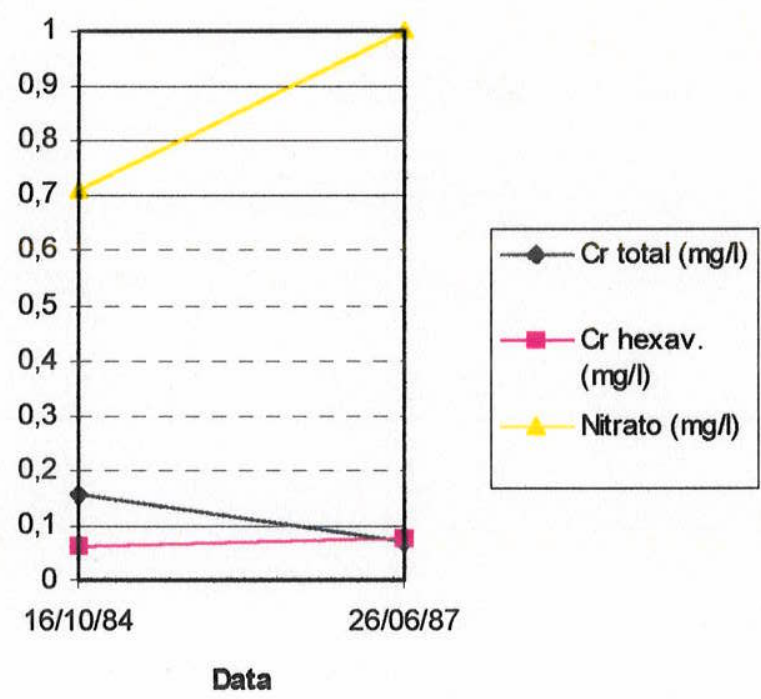

Gráfico 3B: Concentrações de cromo total, hexavalente e nitrogênio nitrato com a data de coleta do poço 2 em Urânia 


\section{Urânia P 3}

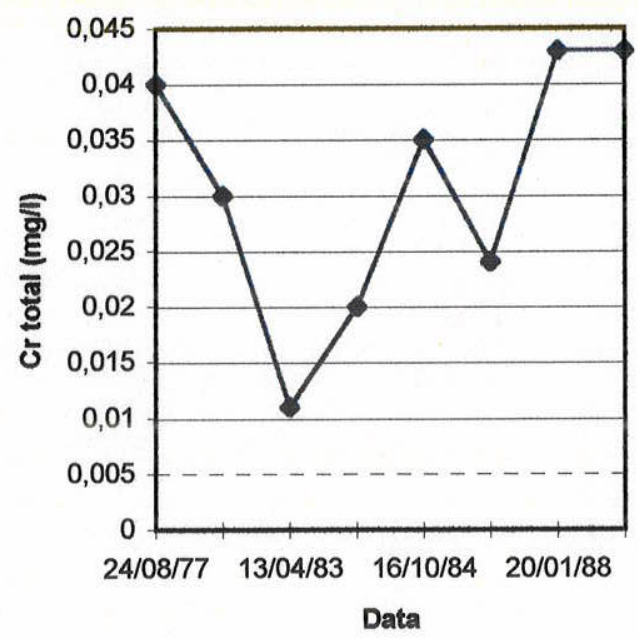

$-\mathrm{Cr}$ total $(\mathrm{mg} / \mathrm{l})$

Gráfico 4A: Concentrações de cromo total (mg/l) com a data de coleta no poço 3 em Urânia.

Urânia P 3

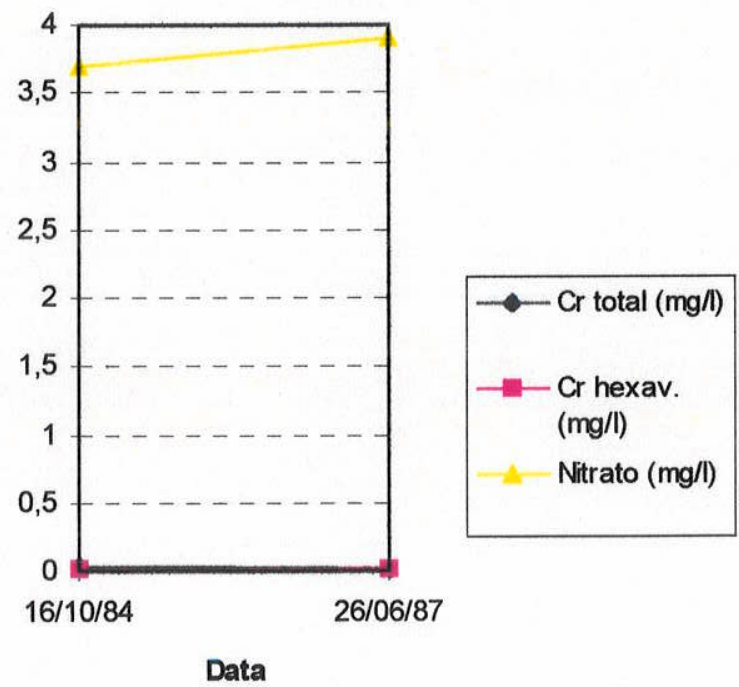

Gráfico 4B: Concentrações de cromo total, hexavalente e nitrogênio nitrato com a data de coleta do poço $3 \mathrm{em}$ Urânia 
Urânia P 4

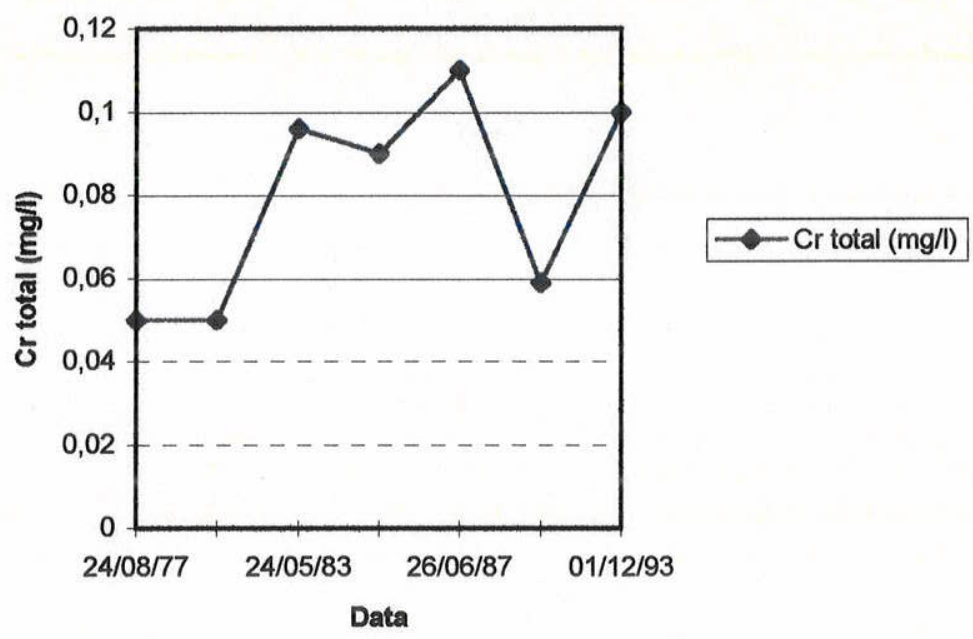

Gráfico 5A: Concentrações de cromo total (mg/l) com a data de coleta no poço 4 em Urânia.

Urânia P 4

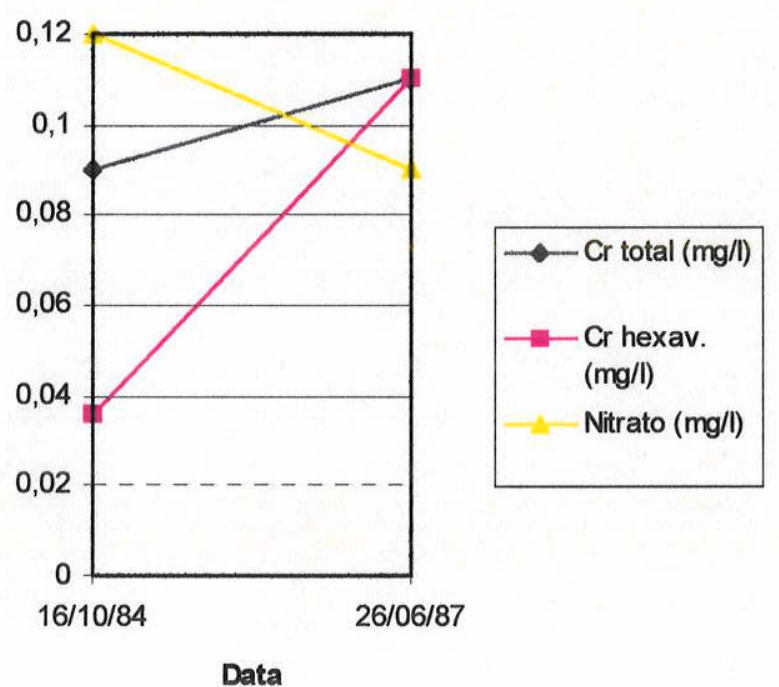

Gráfico 5B: Concentrações de cromo total, hexavalente e nitrogênio nitrato com a data de coleta do poço 4 em Urânia 


\section{Urânia P 5}

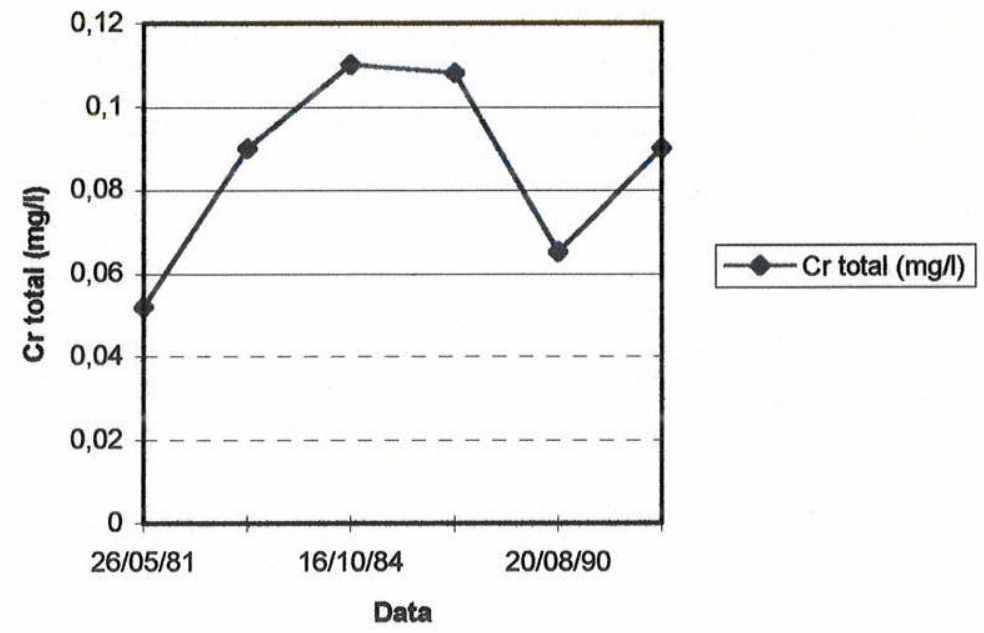

Gráfico 6A: Concentrações de cromo total (mg/l) com a data de coleta no poço 5 em Urânia.

\section{Urânia P 5}

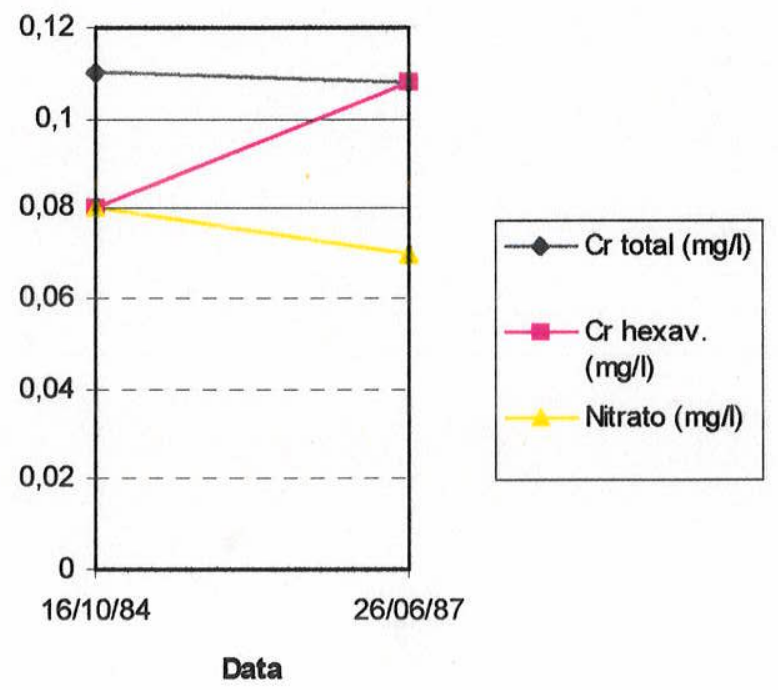

Gráfico 6B: Concentrações de cromo total, hexavalente e nitrogênio nitrato com a data de coleta do poço 5 em Urânia 


\section{Urânia P 6}

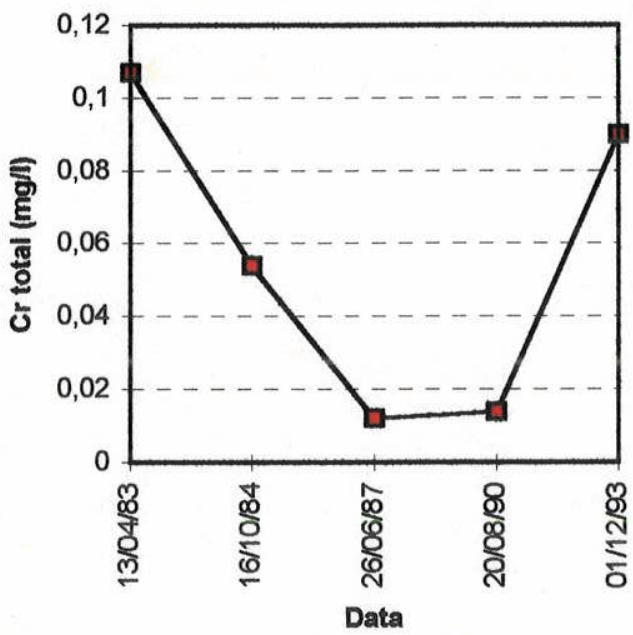

$\rightarrow$ - $\operatorname{Cr}$ total $(\mathrm{mg} / \mathrm{l})$

Gráfico 7A: Concentrações de cromo total $(\mathrm{mg} / \mathrm{l})$ com a data de coleta no poço 6 em Urânia.

\section{Urânia P 6}

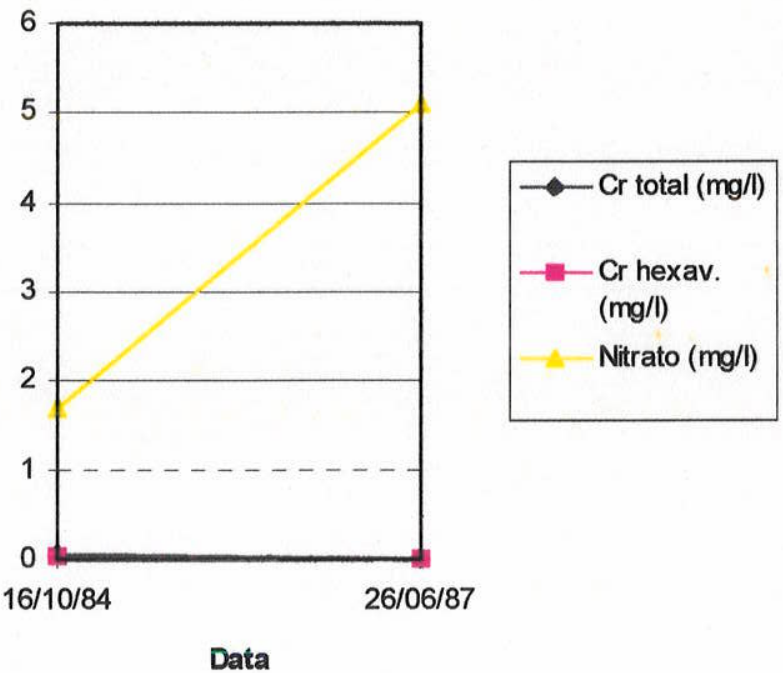

Gráfico 7B: Concentrações de cromo total, hexavalente e nitrogênio nitrato com a data de coleta do poço 6 em Urânia 


\subsubsection{CROMO TOTAL E HEXAVALENTE EM POÇOS SELECIONADOS DE URÂNIA E SANTA SALETE}

Os resultados das análises físico-químicas das águas subterrâneas dos poços de Urânia (P 2, P 4, P 5) e Santa Salete (P 1) encontram-se na tabela 04. Alguns parâmetros, de uma ou outra coleta, deixaram de ser analisados por problemas técnicos.

Por esta tabela nota-se que há uma variação dos teores de cromo total e cromo hexavalẹte em relação ao tempo. Os teores de cromo total variam de 0,08 $0,13 \mathrm{mg} / 1 \mathrm{e}$ os de cromo hexavalente de $0,07-0,10 \mathrm{mg} / 1$, sendo que estes teores estão acima do valor máximo permissível $(0,05 \mathrm{mg} / \mathrm{l})$.

Como não foi possível monitorar os poços durante um ano hidrológico, é díficil uma explicação para estas variações dos teores de cromo. Através dos gráficos 8A e 8B observa-se que os teores de cromo total aumentam na segunda coleta e diminuem na terceira, sendo que, para o cromo hexavalente, o mesmo só ocorre para o poço de Santa Salete.

Os teores anômalos de cromo, apesar de não serem alarmantes, podem comprometer a qualidade das águas subterrâneas, sendo necessário um tratamento de redução deste cromo, que pode encarecer o custo da água potável.

Nestas coletas também foram medidos e analisados outros parâmetros, que apresentam as seguintes variações: temperatura do ar $\left(27-35^{\circ} \mathrm{C}\right)$, temperatura da água $\left(21-26{ }^{\circ} \mathrm{C}\right), \mathrm{pH}(8,6-9,1)$, Eh $(140-195 \mathrm{mV})$, condutividade elétrica à $25^{\circ} \mathrm{C}$ $(150-260 \mu \mathrm{S} / \mathrm{cm})$, sólidos totais dissolvidos $(81,9-128,0 \mathrm{mg} / \mathrm{l})$, sulfato $(0,01-0,10$ $\mathrm{mg} / \mathrm{l})$, bicarbonato $(60-76 \mathrm{mg} / \mathrm{l})$, fluoreto $(0,1-0,3 \mathrm{mg} / \mathrm{l})$, sódio $(24-41 \mathrm{mg} / \mathrm{l})$, potássio $(0,50-2,50 \mathrm{mg} / \mathrm{l})$, ferro total $(0,03-0,21 \mathrm{mg} / \mathrm{l})$, alumínio $(0,01-0,02 \mathrm{mg} / \mathrm{l})$, sílica (9-30 mg/l). As concentrações dos parâmetros STD, sulfato, nitrato, fluoreto, ferro total e manganês estão dentro dos limites de potabilidade. 
Tabela 04: Parâmetros analisados nas coletas de água dos poços de Urânia e Santa Salete.

\begin{tabular}{|c|c|c|c|c|c|c|c|c|c|c|c|c|c|c|c|c|c|c|c|c|c|c|}
\hline \begin{tabular}{|l|} 
Data de \\
coleta
\end{tabular} & Local & Pq & $\begin{array}{l}\text { Hora da } \\
\text { coleta }\end{array}$ & $\left(\begin{array}{l}\text { Cr total } \\
(\mathrm{mg} /)\end{array}\right)$ & $\begin{array}{l}\text { Cr hex. } \\
\text { (mg/) }\end{array}$ & $\mid \begin{array}{l}\text { Temp } \\
\text { ars } \\
\left({ }^{\prime} \mathrm{C}\right)\end{array}$ & $\mid \begin{array}{l}\text { Temp } \\
\text { água } \\
(\mathrm{C})\end{array}$ & $\mathrm{pH}$ & $\begin{array}{l}E h \\
(m v)\end{array}$ & $\begin{array}{l}\text { Cond.e. } \\
(\mu s / \mathrm{cm}) \\
\mathrm{a} 25^{\circ} \mathrm{C}\end{array}$ & $\left|\begin{array}{l}\text { STD } \\
(\mathrm{mg} /)\end{array}\right|$ & $\begin{array}{l}\text { Sulfato } \\
\text { (mgli) }\end{array}$ & $\begin{array}{l}\text { Blcarbon. } \\
\text { (mg/) }\end{array}$ & \begin{tabular}{|l|} 
Nitrog. \\
nitrato \\
$(\mathrm{mg} / \mathrm{N})$
\end{tabular} & $\begin{array}{l}\text { Fluoreto } \\
\text { (mg/) }\end{array}$ & $\mid \begin{array}{l}\text { Sodio } \\
\text { (mg/) }\end{array}$ & $\begin{array}{l}\text { Potás. } \\
\text { (mgn) }\end{array}$ & $\begin{array}{l}\text { Ferro total } \\
(\mathrm{mg} /)\end{array}$ & $\begin{array}{l}\text { Mang. } \\
(\mathrm{mg} / \mathrm{l})\end{array}$ & $\begin{array}{l}\text { Alum. } \\
\text { (mg/) }\end{array}$ & \begin{tabular}{|l|} 
Sillica \\
(mgn)
\end{tabular} & $\begin{array}{l}\text { Res.Seco } \\
180^{\circ} \mathrm{C}\end{array}$ \\
\hline \multirow[t]{5}{*}{$8 / 355$} & Sta. Sal. & $P 1$ & $11: 50$ & 0,12 & 0,09 & 33 & 26 & 8,8 & 140 & 260 & 128,0 & 0,10 & 76 & 0,01 & 0,1 & 29 & 2,50 & 0,07 & - & 0,01 & 20,0 & 159 \\
\hline & Urânia & $\mathrm{P2}^{2}$ & $13: 15$ & 0,10 & 0,08 & 35 & 25 & 8,9 & 195 & 150 & 81,9 & 0,10 & 71 & 0,01 & 0,1 & 26 & 1,80 & 0,07 & -- & 0,01 & 15,0 & 114 \\
\hline & Urania & $\mathrm{P4}$ & $13: 40$ & 0,11 & $0, \infty$ & 34 & 24 & 9,1 & 155 & 150 & 83,0 & 0,10 & 73 & 0,01 & 0,2 & 33 & 0,50 & 0,05 & - & 0,01 & 15.0 & 117 \\
\hline & Urania & P5 & $14: 05$ & 0,10 & 0,08 & 33 & 25 & 9,1 & 196 & 160 & 78,6 & 0,10 & 66 & 0,01 & 0,3 & 37 & 0,50 & 0,03 & - & 0,01 & 9,0 & 107 \\
\hline & & & & & & & & & & & & & & & & & & & & & & \\
\hline \multirow[t]{5}{*}{$30 / 3 / 95$} & Sta. Sal. & $P 1$ & 10.00 & 0,13 & 0,10 & 29 & 26 & 9,0 & - & - & - & 0,10 & - & $=$ & 0,2 & - & $=$ & 0,05 & 0,01 & 0,02 & $=$ & - \\
\hline & Uránia & $\mathrm{P2}$ & 11.00 & 0,11 & 0,08 & 30 & 25 & 8,6 & - & $m$ & $=$ & 0,10 & - & - & 0,2 & - & - & 0,03 & 0,01 & 0,13 & - & - \\
\hline & Urania & $\mathrm{P} 4$ & $11: 10$ & 0,12 & $0, \infty$ & 30 & 26 & 9,0 & - & - & - & 0,10 & - & - & 0,1 & - & - & 0,07 & 0,01 & 0,04 & - & - \\
\hline & Urânia & P5 & $11: 20$ & 0,10 & 0,07 & 30 & 26 & 8,0 & - & - & - & 0,10 & - & - & 0,2 & - & - & 0,07 & 0,01 & 0,14 & - & - \\
\hline & & & & & & & & & & & & & & & & & & & & & & \\
\hline \multirow[t]{4}{*}{305,95} & Sta. Sal. & $P 1$ & $13: 30$ & 0,10 & 0,00 & 27 & 21 & 8,0 & 180 & 200 & 98,0 & 0,06 & 70 & - & 0,1 & - & 2,12 & 0,11 & 0,01 & 0,01 & 30,0 & - \\
\hline & Urania & P2 & $14: 40$ & 0,08 & 0,08 & 27 & 21 & 8,9 & 185 & 160 & 89,0 & 0,00 & 74 & - & 0,1 & - & 1,62 & 0,10 & 0,01 & 0,02 & 28,7 & $\rightarrow$ \\
\hline & Urânia & P4 & $14: 20$ & 0,10 & 0,08 & 27 & 22 & 9,1 & 170 & 160 & 95,0 & 0,01 & 70 & $=$ & 0,1 & - & 0,80 & 0,12 & 0,01 & 0,01 & 25,4 & - \\
\hline & Urânia & 55 & $14: 05$ & 0,08 & 0,08 & 27 & 21 & 9,1 & 170 & 160 & $97, \overline{0}$ & 0,01 & $\infty$ & - & 0,1 & - & 0,65 & 0,21 & 0,01 & 0,02 & 18,5 & - \\
\hline
\end{tabular}

--- não foram medidos/analisados

Valor máximo permissivel (de acordo com a Portaria 36 do Ministério da Saúde):

Cromo total: $0,05 \mathrm{mg} / \mathrm{l}$

STD: $1000 \mathrm{mg} / \mathrm{l}$

Sulfato: $400 \mathrm{mg} / 1$

Nitrogênio nitrato: $10 \mathrm{mg} / 1$

Fluoreto: $0,6-1,7 \mathrm{mg} / 1$

Ferro total: $0,3 \mathrm{mg} /$

Manganês: $0,1 \mathrm{mg} / 1$

\& Alumínio: $0,2 \mathrm{mg} / 1$ 


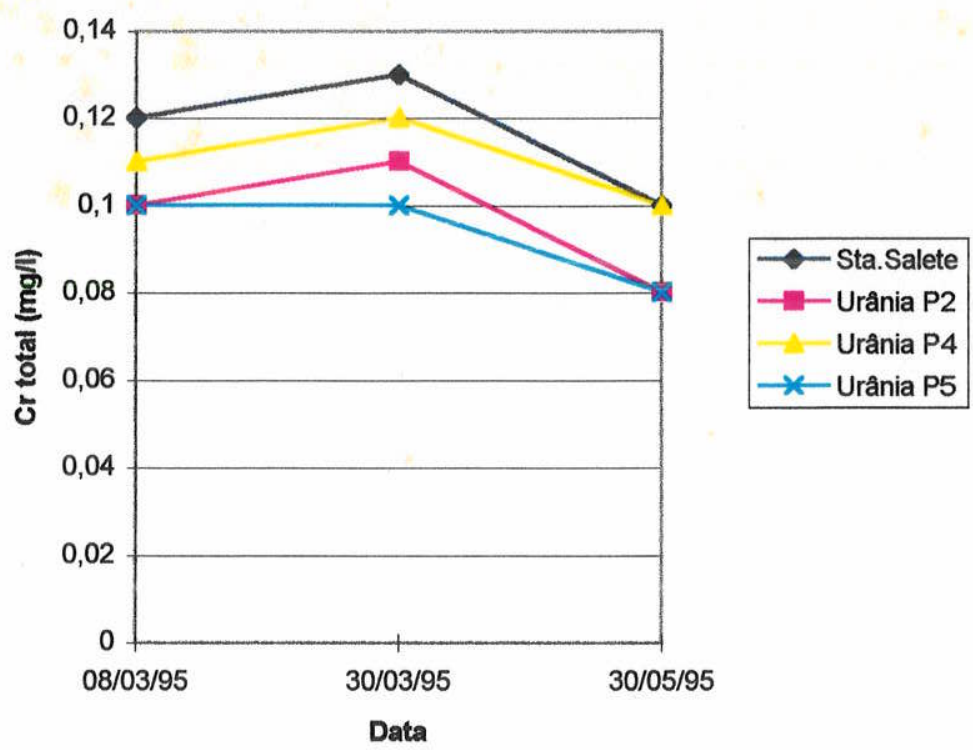

Gráfico 8A: Variação dos teores de cromo total (mg/l) nos poços de Urânia e Santa Salete com o tempo
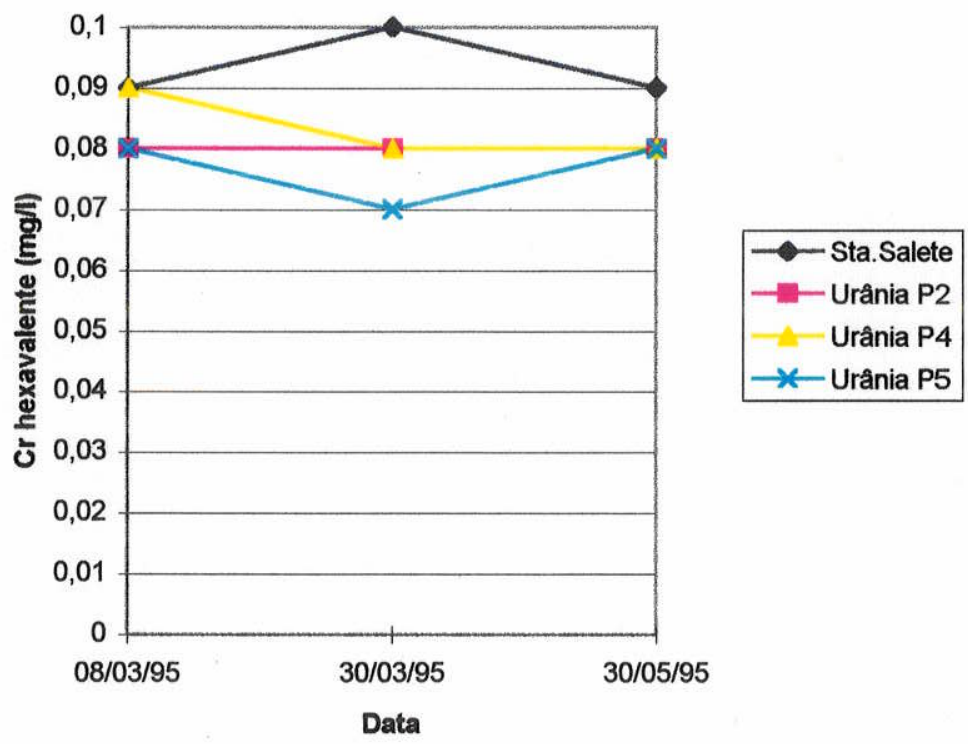

Gráfico 8B: Variação dos teores de cromo hexavalente (mg/1) dos poços de Urânia e Santa Salete com o tempo. 
Como a preocupação maior desta pesquisa é analisar o cromo e por problemas técnicos com a SABESP, não foram feitos alguns parâmetros necessários para um estudo hidroquímico mais completo, que permite fazer um balanço iônico, classificar a composição química destas águas, sua potabilidade para consumo humano, agricultura e pecuária, calcular o potencial para incrustação/corrosão.

\subsubsection{CROMO TOTAL EM POÇOS PERFURADOS APENAS NO GRUPO BAURU OU EM POÇOS COM ENTRADAS DE ÁGUA APENAS NA FORMAÇÃO SERRA GERAL}

Os poços perfurados apenas nos sedimentos do Grupo Bauru e nos basaltos da Formação Serra Geral, juntamente com as concentrações de cromo total das águas subterrâneas e a data de coleta, encontram-se na tabela 05.

Por esta tabela nota-se que na maioria dos poços perfurados apenas nos sedimentos, as concentrações de cromo total são menores do que $0,05 \mathrm{mg} / \mathrm{l}$, variando de 0,005 a $0,040 \mathrm{mg} / 1$. Nos poços de São João das Duas Ponte e Urânia a concentração de cromo total encontra-se abaixo e acima de $0,05 \mathrm{mg} / \mathrm{l}$, num intervalo de 0,011 a $0,155 \mathrm{mg} / 1$. Nos poços com entradas de água apenas nos basaltos, as concentrações de cromo total encontram-se abaixo de $0,05 \mathrm{mg} / \mathrm{l}$, variando de 0,007 a $0,018 \mathrm{mg} / 1$.

Estes resultados mostram que as maiores concentrações de cromo total são encontradas em águas provenientes dos sedimentos do Sistema Aquífero Bauru. 
Tabela 05: Concentrações de cromo total $(\mathrm{mg} / \mathrm{l})$ em poços perfurados apenas no Grupo Bauru e poços com entradas de água apenas na Formação Serra Geral

\begin{tabular}{|c|c|c|c|}
\hline $\begin{array}{l}\text { Poços perfurados } \\
\text { apenas no G.Bauru }\end{array}$ & $\begin{array}{l}\text { Variaçăo de cromo total }(\mathrm{mg} / \mathrm{l}) \\
\text { com a data de coleta }\end{array}$ & $\begin{array}{l}\text { Poços com entradas de } \\
\text { água apenas na F. S.Geral }\end{array}$ & $\begin{array}{l}\text { Concentraçăo de cromo total } \\
(\mathrm{mg} / \mathrm{l}) \text { com a data de coleta }\end{array}$ \\
\hline Auriflama (P 2) & $0,005(26 / 04 / 84) * 0,011(28 / 02 / 89)$ & Cardoso (P 1) & $0,007(15 / 02 / 89)$ \\
\hline Auriflama (P 3) & $0,005(20 / 10 / 81)-0,005(26 / 04 / 84)$ & Paranapua $(P 3)$ & $0,018(29 / 12 / 79)$ \\
\hline Auriflama (P 7) & $0,018(26 / 04 / 84)$ & Ríolândia (P 5) & $0,008(08 / 02 / 85)$ \\
\hline Macedónia (P 1) & $0,014(13 / 05 / 81)-0,021(09 / 08 / 88)$ & Riolândia (P 6) & $0,006(18 / 01 / 86)$ \\
\hline Palm.Oeste (P 1) & $0,005(\{2 / 03 / 90)$ & S.I.Marinheiro (P 1) & $0,008(11 / 10 / 80)$ \\
\hline Palm.Oeste (P 2) & $0,005(12 / 03 / 90)$ & & \\
\hline Pedranópolis (P 5) & $0,005(20 / 07 / / 85)$ cromo hexaval. & & \\
\hline S.J.D.Pontes (P 2) & $0,040(18 / 05 / 84) \sim 0,070(06 / 05 / 93)$ & & \\
\hline Urania (P 1) & $0,023(26 / 06 / 87)-0,122(20 / 08 / 90)$ & & \\
\hline Urânia (P 2) & $0,040(24 / 08 / 77)-0,155(16 / 10 / 84)$ & & \\
\hline Urânia $(P 3)$ & $0,011(13 / 04 / 83)-0,043(20 / 01 / 8.3)$ & & \\
\hline
\end{tabular}




\subsection{AVALIAÇÃO GEOQUÍMICA DAS ÁGUAS, SEDIMENTOS E ROCHAS BASÁLTICAS DE URÂNIA-S.P.}

As amostras de sedimentos de Urânia são de ocorrência superficial, estando bem alteradas pelos fenômenos intempéricos. As de sedimentos do poço P 9 também devem ser vistas com cuidado, uma vez que não são conhecidos os teores de cromo da lama de perfuração (bentonita), e não é possível extraí-la das amostras de material argiloso.

\subsubsection{ANÁLISES DE ÁGUAS}

$\mathrm{Na}$ figura 05 encontra-se um esboço do perfil geológico do poço P 9. A figura 06 mostra a localização do poço.Este poço foi perfurado em janeiro/95 no município de Urânia pela GEOPLAN. Localiza-se próximo ao Córrego Comprido, sendo suas coordenadas geográficas $7763,40 / 539,25$ e a cota topográfica da boca do poço, 420 metros. Possui 67,60 metros de sedimentos da Formação Adamantina, e a partir daí, até a profundidade de 270 metros, encontram-se os basaltos da Formação Serra Geral. Toda a extensão de sedimento foi cimentada. Após a perfuração, o poço foi abandonado devido a sua baixa vazão $\left(2,2 \mathrm{~m}^{3} / \mathrm{h}\right)$. Tomou-se o cuidado de lacrar o poço.

Durante a coleta de água do poço 9 em três profundidades diferentes (114, 180-182, 270 metros) para análise de cromo total, mediu-se em campo a temperatura do ar, da água, o $\mathrm{pH}$, a condutividade elétrica, os sólidos totais dissolvidos (STD) (tabela 06). A 270 metros foram analisados os teores dos seguintes íons: cloreto $(9 \mathrm{mg} / \mathrm{l})$, sulfato $(1,98 \mathrm{mg} / \mathrm{l})$, cálcio $(6 \mathrm{mg} / 1)$, magnésio $(7$ $\mathrm{mg} / \mathrm{l})$, ferro total $(2,3 \mathrm{mg} / \mathrm{l})$, alumínio $(0,02 \mathrm{mg} / \mathrm{l})$. 


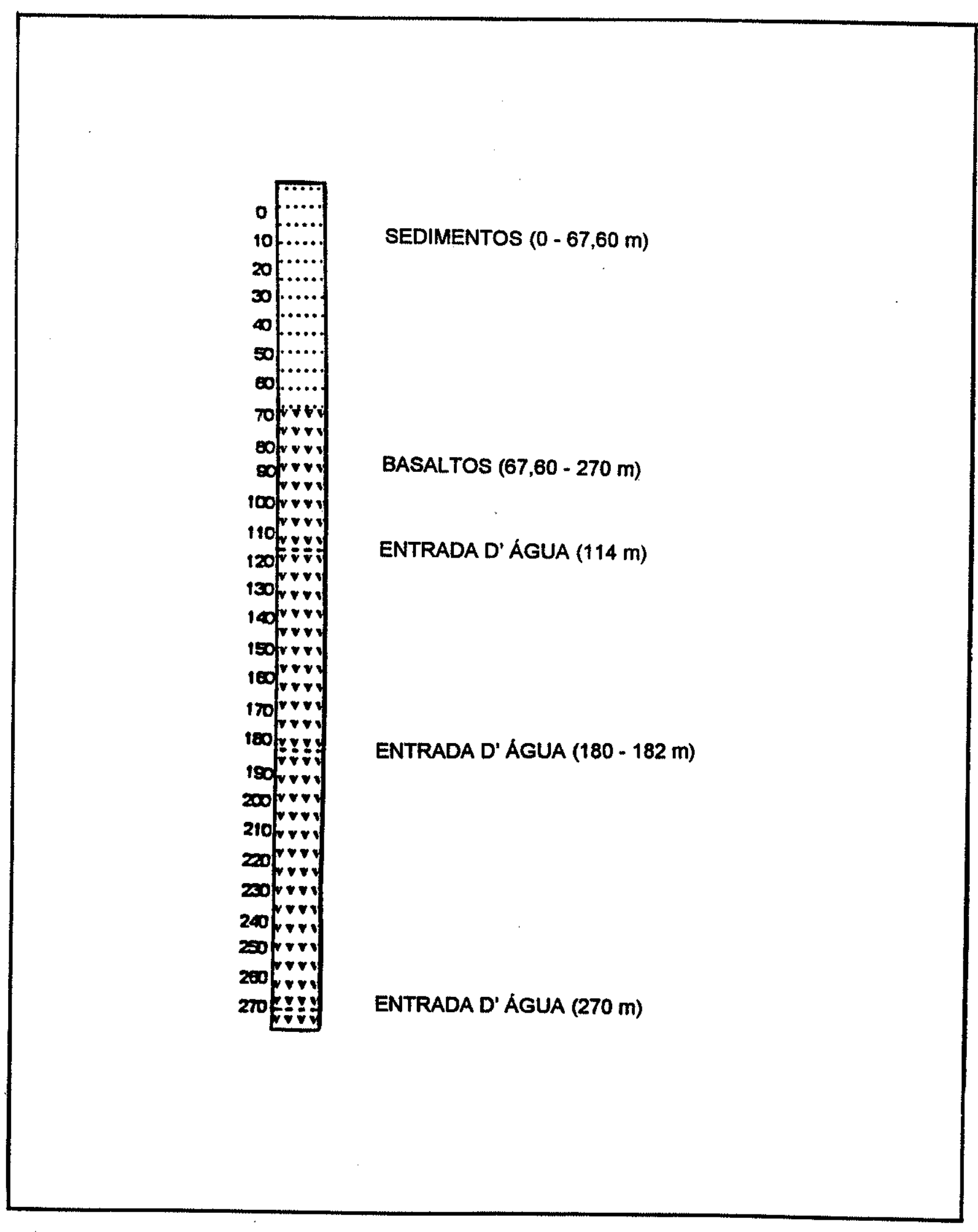

Figura 05: Esboço do perfil geológico do poço 9 em Urânia.

Escala vertical 1:2.000, o diâmetro do poço não está em escala. 




Figura 06: Localização de poços tubulares e de pontos de amostragem de sedimentos na sede do município de Urânia.

Fonte: Folha topográfica SF 22-D-1-2-Santa Albertina, Instituto Geográfico e Geológico de São Paulo, 1965 (simplificado). 
Tabela 06: Resultados das análises físico-químicas de águas subterrâneas do poço 9 , em três profundidades.

\begin{tabular}{|l|l|l|l|l|l|l|l|}
\hline $\begin{array}{l}\text { Profund } \\
(\mathrm{m})\end{array}$ & $\begin{array}{l}\text { Data de } \\
\text { coleta }\end{array}$ & $\begin{array}{l}\text { Cr total } \\
(\mathrm{mg} / \mathrm{l})\end{array}$ & $\begin{array}{l}\text { Temp. ar } \\
\left({ }^{\circ} \mathrm{C}\right)\end{array}$ & $\begin{array}{l}\text { Temp. água } \\
\left({ }^{\circ} \mathrm{C}\right)\end{array}$ & $\begin{array}{l}\text { pH } \\
(\mu \mathrm{S} / \mathrm{cm}) \mathrm{à} \\
25^{\circ} \mathrm{C}\end{array}$ & $\begin{array}{l}\text { STD } \\
(\mathrm{mg} / \mathrm{l})\end{array}$ \\
\hline 114 & $13 / 01 / 95$ & 0,03 & 35 & 28 & 9,9 & 337 & 169 \\
\hline $180-182$ & $14 / 01 / 95$ & 0,01 & --- & -- & 9,9 & 216 & 206 \\
\hline 270 & $15 / 01 / 95$ & 0,03 & 38 & 28 & 9,7 & 281 & 143 \\
\hline
\end{tabular}

--n não foram medidos

Como mostra a tabela 06, a concentração de cromo total a 114 metros é de $0,03 \mathrm{mg} / \mathrm{l}$; a $180-182$ metros é de $0,01 \mathrm{mg} / \mathrm{l}$; a 270 metros é $0,03 \mathrm{mg} / \mathrm{l}$. É importante ressaltar que nestas profundidade encontram-se os basaltos e que nos sedimentos superiores houve cimentação.

Foram feitas coletas de água em dois poços que só atingem os sedimentos, e as concentrações de cromo total são mais altas do que as anteriores. No poço da Fazenda Jatobá (PF), com coordenadas geográficas aproximadas de $7763,57 / 537,55$, no município de Urânia, a concentração de cromo total é de 0,09 $\mathrm{mg} / \mathrm{l}$. No poço do Posto de Gasolina Garção (PG), onde as coordenadas geográficas aproximadas são 7762,75/535,30, também em Urânia, a concentração é de 0,05 $\mathrm{mg} / \mathrm{l}$ (tabela 07). A localização destes poços encontra-se na figura 06 .

Amostras coletadas no Córrego Comprido apresentaram concentrações de cromo total e hexavalente abaixo do limite de deteç̧ão do equipamento $(<0,0025$ $\mathrm{mg} / \mathrm{l})$. Foram coletadas em locais diferentes, uma ao longo da extensão do Córrego e a outra numa mina que deságua no Córrego e possui despejo do lixo municipal, do matadouro municipal e de um depósito de ferro velho.

Estes resultados mostram que as concentrações de cromo em poços que só atingem os sedimentos são mais elevadas do que as do poço $P$, que possui entradas de água apenas nos basaltos.As concentrações de cromo nas águas 
subterrâneas também são superiores às encontradas nas águas do Córrego Comprido.

Tabela 07: Resultados das análises de parâmetros físico-químicos das águas subterrâneas dos poços da Fazenda Jatobá e Posto Garção.

\begin{tabular}{|l|l|l|l|l|l|l|l|}
\hline Local & $\begin{array}{l}\text { Data de } \\
\text { coleta }\end{array}$ & $\begin{array}{l}\text { Cr total } \\
(\mathrm{mg} / \mathrm{l})\end{array}$ & $\begin{array}{l}\text { Temp. ar } \\
\left({ }^{\circ} \mathrm{C}\right)\end{array}$ & $\begin{array}{l}\text { Temp.água } \\
\left({ }^{\circ} \mathrm{C}\right)\end{array}$ & $\begin{array}{l}\text { pH } \\
(\mu \mathrm{S} / \mathrm{cm}) \text { à } \\
25^{\circ} \mathrm{C}\end{array}$ & $\begin{array}{l}\text { STD } \\
(\mathrm{mg} / \mathrm{l})\end{array}$ \\
\hline Faz.Jatobá & $13 / 01 / 95$ & 0,09 & 31 & $-\cdots$ & 9,1 & 128 & 64,6 \\
\hline Posto Garção & $14 / 01 / 95$ & 0,05 & 30 & 26 & 7,3 & 235 & 108 \\
\hline
\end{tabular}

--m não foi medida

\subsubsection{ANÁLISE DOS SEDIMENTOS DE URÂNIA E DO POÇO 9}

Foram analisadas cinco amostras de sedimentos, sendo que duas afloram em Urânia e três são do poço 9.

As amostras que afloram em Urânia são as de código A 4 e A 6 . A primeira é um solo argiloso amarronzado e foi coletada à margem do Córrego Comprido, próxima ao poço 9. A segunda, apresentava-se menos alterada, com maior coesão e foi descrita como um argilito avermelhado, coletado próximo à Lagoa de Aeração, onde se localiza o poço 5, que possui coordenadas geográficas 7761,50/538,20.A localização destes pontos de amostragem e do poço 5 encontra-se na figura 06.

As amostras do poço 9 são as de código 18, 30, 54, sendo que estes códigos referem-se às profundidades em metros que foram coletadas. Estes sedimentos são argilo-siltosos, na maioria das vezes avermelhados.

Foram analisados os seguintes elementos: zinco $(\mathrm{Zn})$, cromo $(\mathrm{Cr})$, cobre $(\mathrm{Cu})$, zircônio $(\mathrm{Zr})$ e ítrio (Y). Suas concentrações são apresentadas na tabela 08 e comparadas com as concentrações médias destes elementos encontrados em folhelhos (Krauskopf, 1979; tabela 09). 
Comparando as tabelas 08 e 09 nota-se que as concentrações de $\mathrm{Zn}$ dos sedimentos de Urânia, estão próximas às da média da crosta terrestre. As concentrações de Cu estão abaixo da média. No entanto, as concentrações de $\mathrm{Cr}$ e $\mathrm{Zr}$ dos sedimentos de Urânia nem sempre coincidem com as médias da crosta terrestre, sendo que o cromo nos sedimentos de Urânia está acima da média em todas as amostras. As concentrações de $\mathrm{Cr}$ e $\mathrm{Zr}$ na amostra $\mathrm{A} 4$ estão muito acima da média encontrada na crosta terrestre.

O ICP-AES possui um limite de deteç̧ão dos elementos, de $20 \mathrm{ppm}$, para o tipo de abertura de amostra que foi seguido. Por isso, as concentrações com o sinal $<20$ ppm não possuem um valor absoluto.

Com a amostra A 6 foi feito um teste de reproducibilidade. Os resultados de A 6 e A 6 (rep.) são semelhantes, mostrando que existe uma boa reprodução dos resultados.

Tabela 08: Concentrações (ppm) de alguns elementos analisados nos sedimentos do poço 9 em Urânia.

\begin{tabular}{|l|l|l|l|l|l|l|}
\hline \multirow{2}{*}{$\begin{array}{l}\text { Elementos } \\
\text { analisados (ppm) }\end{array}$} & \multicolumn{2}{|l|}{ Amostras } \\
\cline { 2 - 8 } & $\mathrm{A} 4$ & $\mathrm{~A} 6$ & $\mathrm{~A} 6$ (rep.) & 18 & 30 & 54 \\
\hline $\mathrm{Zn}$ & 87 & 123 & 123 & 51 & 219 & 45 \\
\hline $\mathrm{Cr}$ & 561 & 231 & 233 & 131 & 310 & 174 \\
\hline $\mathrm{Cu}$ & $<20$ & $<20$ & $<20$ & $<20$ & $<20$ & $<20$ \\
\hline $\mathrm{Zr}$ & 599 & 329 & 332 & 151 & 230 & 169 \\
\hline $\mathrm{Y}$ & $<20$ & 83 & 84 & $<20$ & $<20$ & $<20$ \\
\hline
\end{tabular}

A 6 (rep.): Reproducibilidade.

Tabela 09: Abundância média dos elementos em folhelhos (ppm).

\begin{tabular}{|c|c|c|c|c|c|c|}
\hline $\begin{array}{c}\text { Folhelho } \\
(\mathrm{ppm})\end{array}$ & $\mathrm{Zn}$ & $\mathrm{Cr}$ & $\mathrm{Cu}$ & $\mathrm{Zr}$ & $\mathrm{Sc}$ & $\mathrm{Y}$ \\
\cline { 2 - 7 } & 90 & 100 & 50 & 180 & 15 & 35 \\
\hline
\end{tabular}

Fonte: Krauskopf, 1979. 


\subsubsection{ANÁLISE DOS BASALTOS DO POÇO 9}

As onze amostras de basaltos do poço 9 foram descritas utilizando-se uma lupa binocular do DMP. A maioria delas é melanocrática de textura fanerítica fina e não apresenta vesículas. Algumas amostras contêm calcita, que foi extraída por catação por pinça. Uma descrição sucinta encontra-se no anexo 03.

Nos basaltos determinou-se as concentrações dos seguintes elementos: $\mathrm{SiO}_{2}$, $\mathrm{Al}_{2} \mathrm{O}_{3}, \mathrm{Fe}_{2} \mathrm{O}_{3}, \mathrm{MgO}, \mathrm{CaO}, \mathrm{Na}_{2} \mathrm{O}, \mathrm{K}_{2} \mathrm{O}, \mathrm{TiO}_{2}, \mathrm{P}_{2} \mathrm{O}_{5}, \mathrm{MnO}, \mathrm{Cr}, \mathrm{Ni}, \mathrm{V}, \mathrm{Ba}, \mathrm{Sr}$ (tabela 10). Na tabela 11 são apresentadas as concentrações médias de alguns elementos encontrados nos basaltos, segundo Krauskopf, 1979.

Pela tabela 10 é possível constatar que os basaltos podem ser divididos em quatro grupos com características geoquímicas diferentes, de acordo com a profundidade. Estes grupos apresentam concentrações equivalentes para cada elemento.

$O$ grupo I corresponde às profundidades 70,90 e 110 metros. $O$ grupo II, 130,150 e 170 metros. O grupo III, 190, 210 e 230 metros, e o grupo IV, 250 e 270 metros.

Os topos dos derrames, identificados pelo caráter alterado e amigdaloidal dos basaltos, encontram-se nos seguintes intervalos de profundidade : 110-124 metros, 178-180 metros, 240-246 metros.

Os basaltos da Bacia do Paraná podem ser classificados em três grupos, de acordo com a porcentagem de $\mathrm{P}_{2} \mathrm{O}_{5}$ e $\mathrm{TiO}_{2}$ (Piccirillo, 1988):

- HPT (high $\mathrm{P}_{2} \mathrm{O}_{5}$ e $\mathrm{TiO}_{2}$ ) $>3 \% \mathrm{TiO}_{2}$;

- LPT (low $\mathrm{P}_{2} \mathrm{O}_{5}$ e $\mathrm{TiO}_{2}$ ) <2\% $\mathrm{TiO}_{2}$;

- IPT (intermediate $\mathrm{P}_{2} \mathrm{O}_{5}$ e $\mathrm{TiO}_{2}$ ) 2-3\% $\mathrm{TiO}_{2}$

Nos basaltos do poço 9 de Urânia podem ser claramente identificados representantes de todos estes três grupos. O grupo II é classificado como LPT, e 
apresenta baixas concentrações de Ti e $\mathrm{P}$ e altas de $\mathrm{Mg}, \mathrm{Ca}, \mathrm{Cr}$ e $\mathrm{Ni}$. O grupo III corresponde ao HPT, com altas concentrações de Fe, Ti, P, Ba, Sr. Os HPT são considerados predominantes no Estado de São Paulo.

Comparando as tabelas 10 e 11 , nota-se que as concentrações dos elementos $\mathrm{Cr}$ e Ni em todas as rochas estão abaixo da média de basaltos da crosta terrestre. As concentrações de V estão muito acima da média. Os elementos Ba e Sr apresentam concentrações próximas às da média. 
Tabela 10: Concentrações (ppm) de alguns elementos analisados nos basaltos do poço 9 em Urânia.

\begin{tabular}{|l|l|l|l|l|l|l|l|l|l|l|l|}
\hline $\begin{array}{l}\text { Elementos } \\
\text { analisados } \\
\text { (ppm) }\end{array}$ & Profun $(\mathrm{m})$ & 90 & 110 & 130 & 150 & 170 & 190 & 210 & 230 & 250 & 270 \\
\hline SiO2 & 50,14 & 52,07 & 49,33 & 50,01 & 50,85 & 51,47 & 48,74 & 50,40 & 49,87 & 48,57 & 49,64 \\
\hline Al2O3 & 12,85 & 13,16 & 13,54 & 13,74 & 13,66 & 13,59 & 12,89 & 12,44 & 12,56 & 13,16 & 12,96 \\
\hline Fe2O3 & 14,38 & 14,48 & 14,96 & 13,74 & 13,76 & 13,59 & 15,92 & 16,41 & 16,00 & 15,89 & 15,65 \\
\hline $\mathrm{MgO}$ & 5,17 & 5,47 & 5,37 & 6,25 & 6,18 & 6,10 & 4,26 & 4,46 & 4,49 & 5,46 & 5,33 \\
\hline $\mathrm{CaO}$ & 9,20 & 9,70 & 9,30 & 10,45 & 10,18 & 10,01 & 8,55 & 8,43 & 8,53 & 9,96 & 9,73 \\
\hline Na2O & 2,86 & 2,64 & 3,04 & 2,48 & 2,49 & 2,47 & 2,75 & 2,69 & 2,63 & 2,52 & 2,51 \\
\hline $\mathrm{K} 2 \mathrm{O}$ & 1,55 & 1,02 & 1,56 & 0,73 & 0,98 & 1,01 & 1,26 & 1,46 & 1,46 & 0,67 & 1,03 \\
\hline TiO2 & 2,02 & 1,97 & 2,06 & 1,87 & 1,80 & 1,85 & 3,69 & 3,84 & 3,67 & 2,70 & 2,65 \\
\hline $\mathrm{P2O5}$ & 0,25 & 0,24 & 0,26 & 0,23 & 0,23 & 0,24 & 0,57 & 0,57 & 0,54 & 0,29 & 0,29 \\
\hline $\mathrm{MnO}$ & 0,20 & 0,19 & 0,25 & 0,23 & 0,21 & 0,21 & 0,23 & 0,25 & 0,23 & 0,19 & 0,22 \\
\hline Total & 98,62 & 100,9 & 99,67 & 99,73 & 100,3 & 100,5 & 98,86 & 101,0 & 99,98 & 99,41 & 100 \\
\hline & & & & & & & & & & & \\
\hline $\mathrm{Cr}$ & 94 & 84 & 101 & 159 & 168 & 164 & 20 & 20 & 20 & 55 & 59 \\
\hline $\mathrm{Ni}$ & 37 & 50 & 44 & 71 & 70 & 75 & $<20$ & $<20$ & 20 & 32 & 29 \\
\hline $\mathrm{V}$ & 470 & 432 & 459 & 408 & 400 & 410 & 481 & 469 & 493 & 508 & 507 \\
\hline $\mathrm{Ba}$ & 387 & 293 & 373 & 272 & 258 & 263 & 495 & 457 & 455 & 289 & 311 \\
\hline $\mathrm{Sr}$ & 395 & 387 & 385 & 392 & 339 & 330 & 435 & 421 & 426 & 458 & 439 \\
\hline & & & & & & & \\
\hline
\end{tabular}

Tabela 11: Abundância média dos elementos em basaltos (ppm).

\begin{tabular}{|c|c|c|c|c|c|c|}
\hline $\begin{array}{c}\text { Basalto } \\
(\mathrm{ppm})\end{array}$ & $\mathrm{Cr}$ & $\mathrm{Ni}$ & $\mathrm{Co}$ & $\mathrm{V}$ & $\mathrm{Ba}$ & $\mathrm{Sr}$ \\
\cline { 2 - 7 } & 200 & 150 & 48 & 250 & 300 & 450 \\
\hline
\end{tabular}

Fonte: Krauskopf, 1979 


\subsection{LEVANTAMENTO SOBRE EVENTUAIS PROBLEMAS DE SAÚDE DA POPULAÇÃO ABASTECIDA POR ÁGUAS SUBTERRÂNEAS COM TEORES DE CROMO ACIMA DO LIMITE DE POTABILIDADE}

Foram feitos contatos com o Escritório Regional de Saúde de Jales (ERSA) e com o Centro de Saúde de Urânia para se obter informação sobre a existência de estudos na região que comprovassem doenças causadas pela ingestão de água contendo cromo.

Segundo Gisele Maria Pietrobon Garcia do ERSA, não há nenhum estudo que comprove que a ingestão de água contendo cromo causa problemas à população da região. Não existe registrado nenhum caso.

Setuo Kitayama, médico cirurgião do ERSA, lembra que algumas referências bibliográficas colocam que o cromo, por ser um metal pesado, difícil de ser eliminado pelo organismo e com efeito acumulativo, causa tumores malígnos.

Kitayama diz que existem casos de tumores malígnos na região de Jales. Porém, não é possível relacionar estes tumores com a ingestão de água contendo cromo, pois não foi feito nenhum estudo. Também não existe um estudo comparativo entre as cidades da região em relação à incidência de câncer.

José Rubens Gitti, Coordenador e Diretor do Centro de Saúde de Urânia, coloca que existem bibliografias que citam o problema causado pelo cromo através da ingestão de água. Entretanto não foi feito nenhum estudo em Urânia. Na cidade existem aproximadamente vinte pessoas com câncer (figado, garganta, estômago) mas não se sabe o que provocou a doença. 


\section{SÍNTESE DOS RESULTADOS}

-a anomalia de cromo nas águas subterrâneas foi constatada em vários municípios e distritos do noroeste paulista. As concentrações deste elemento estão distribuídas de forma irregular, tanto temporal quanto espacialmente;

-o cromo total encontra-se distribuído nas águas subterrâneas de várias localidades da região noroeste do Estado de São Paulo. Dentre as 54 localidades analisadas, no período de 1977 a 1993, observou-se que as concentrações deste elemento, na maioria delas, são menores ou iguais ao limite de potabilidade $(\leq 0,05$ $\mathrm{mg} / \mathrm{l})$. Em Dirce Reis, Mangaratu e Santa Salete, as concentrações estão acima deste limite $(>0,05 \mathrm{mg} / \mathrm{l})$. Há ainda localidades em que as concentrações variam abaixo e acima deste limite, no intervalo de 0,005 a 0,155 mg/l. Estas concentrações variam com a data de coleta num mesmo poço e também de poço para poço numa mesma localidade;

-nas 12 localidades do noroeste paulista onde foi realizada coleta de água subterrânea para análise de cromo hexavalente observou-se que em nove destas localidades, as concentrações são menores ou iguais ao limite de potabilidade $(\leq 0,05 \mathrm{mg} / \mathrm{l}$ ) (Américo de Campos, Aparecida do Bonito, Aspásia, Cosmorama, Meridiano, Parisi, Simonsen, Susanápolis, Votuporanga). Santa Salete porém, apresenta concentração maior do que $0,05 \mathrm{mg} / \mathrm{l}$. Em Santa Rita D'Oeste e Urânia, as concentrações variam abaixo e acima de $0,05 \mathrm{mg} / \mathrm{l}$, dependendo do poço;

-as concentrações de cromo total, cromo hexavalente e nitrogênio nitrato das águas subterrâneas de Urânia, no período de 1977 a 1993 também apresentam uma distribuição irregular em relação ao poço amostrado e a data de coleta; 
-as três coletas de águas realizadas nos poços de Urânia (P 2, P 4, P 5) e Santa Salete (P 1), num período de 83 dias, mostraram que as concentrações de cromo total e hexavalente estão acima do limite de potabilidade. Nos quatro poços, em todas as três coletas, estas concentrações variam de 0,08 a $0,13 \mathrm{mg} / \mathrm{l}$ para cromo total e de 0,07 a $0,09 \mathrm{mg} / 1$ para cromo hexavalente. As concentrações dos parâmetros STD, sulfato, nitrogênio nitrato, fluoreto, ferro total e manganês, analisados nestas coletas, estão abaixo dos limites de potabilidade;

-a maioria dos poços perfurados apenas nos sedimentos do Grupo Bauru apresentam concentrações de cromo total menor do que $0,05 \mathrm{mg} / \mathrm{l}$, variando de 0,005 a 0,040 mg/l. Nos poços de São João das Duas Pontes e Urânia (P 1, P 2, P 3) a concentração de cromo total encontra-se abaixo e acima de $0,05 \mathrm{mg} / \mathrm{l}$, num intervalo de 0,011 a $0,155 \mathrm{mg} / \mathrm{l}$. Estes resultados são de análises feitas no período de 1977 a 1990 ;

-nos poços com entradas de água apenas nos basaltos, as concentrações de cromo total encontram-se abaixo de $0,05 \mathrm{mg} / \mathrm{l}$, variando de 0,007 a $0,018 \mathrm{mg} / \mathrm{l}$, no período de 1979 a 1989;

-as análises de água do poço 9 em Urânia, em três profundidades que só atingem os basaltos $(114,180-182,270$ metros), mostraram concentrações de cromo total variando de 0,01 a $0,03 \mathrm{mg} / \mathrm{l}$;

-as análises de água de dois poços que só atingem os sedimentos, um na Fazenda Jatobá e outro no Posto de Gasolina Garção, apresentaram concentrações de cromo total variando de 0,05 a $0,09 \mathrm{mg} / \mathrm{l}$; 
-as amostras de sedimentos de Urânia (2 que afloram na área e 3 do poço 9) mostraram concentrações de cromo acima da média encontrada em sedimentos similares da crosta terrestre. Em uma das amostras que aflora na cidade, a concentração de cromo e zircônio está muito acima da média;

-as onze amostras de basaltos do poço 9 em Urânia, coletadas a diferentes profundidades, apresentam concentrações de cromo e níquel abaixo da média dos basaltos da crosta terrestre. As concentrações de Vanádio estão muito acima desta média, e

-um levantamento sobre a sáude da população de Urânia mostrou que não foi realizado nenhum estudo na região que comprovasse doenças causadas pela ingestão de água contendo cromo acima do limite de potabilidade. 


\section{CONCLUSÕES}

Através da integração dos dados e do estudo sistemático dos teores de cromo nas águas, sedimentos e rochas, obteve-se as seguintes conclusões:

- a anomalia de cromo extende-se além da cidade de Urânia, a outros municípios e distritos do noroeste paulista, não significando que em locais onde não foram feitas análises químicas das águas subterrâneas, ela não esteja presente;

- o cromo nas águas subterrâneas de diversas localidades da região noroeste do Estado de São Paulo apresenta concentrações variáveis, sendo que em alguns locais ultrapassam os limites máximos permissíveis para o consumo humano, afetando a qualidade destas águas utilizadas para abastecimento público;

- as concentrações de cromo nas águas subterrâneas variam com a data de coleta destas águas num mesmo poço, de poço para poço numa mesma localidade e de localidade para localidade. Este estudo mostra que a anomalia de cromo está distribuída de forma irregular, tanto temporal quanto espacialmente;

- a origem do cromo é discutível, apesar de fortes evidências de ser natural, são necessários estudos mais aprofundados para um maior esclarecimento. Algumas das evidências do cromo ter origem natural são: a anomalia de cromo apresenta-se distribuída por uma ampla região; foram encontradas altas concentrações de cromo nos sedimentos de Urânia;

-concentrações de cromo nas águas de poços perfurados apenas nos sedimentos da Formação Adamantina do Grupo Bauru, apresentam valores mais altos do que nas águas de poços com entradas de água apenas nos basaltos da Formação Serra Geral. 
Estes dados, somados às altas concentrações de cromo encontradas nos sedimentos de Urânia, evidenciam que se a origem é natural, pode estar associada aos sedimentos da Formação Adamantina;

- não existem conclusões relevantes se os teores de cromo acima do limite de potabilidade podem causar problemas à saúde da população abastecida por estas águas. 


\section{RECOMENDAÇÕES}

-cuidados devem ser tomados com as águas subterrâneas da região noroeste do do Estado de São Paulo, uma vez que são utilizadas para consumo humano e que apresentam concentrações de cromo total acima do limite de potabilidade. É conveniente ressaltar que a SABESP já vem realizando testes em Santa Salete, com o material $\mathrm{KDF}-\mathrm{W}$, que reduz as concentrçoes de cromo através da troca de íons ( $\mathrm{Zn}, \mathrm{Cu}$ ), deixando as concentrações destes mais altas, porém, não prejudiciais à saúde humana;

-há necessidade de se fazer um estudo com a população da região para comprovar se existem casos de doenças causadas pela ingestão de água contendo cromo acima do limite permissivel. As últimas informações que se tem é que a Secretaria da Saúde já vem se organizando para desenvolver este estudo;

- coletar outras amostras de sedimentos e basaltos de poços que serão perfurados na região para análise de cromo. A partir destes resultados será possível estabelecer uma distribuição espacial e em profundidade deste elemento;

-dar continuidade ao monitoramento mensal, com coleta e análise fisicoquímica das águas nos poços selecionados de Urânia e Santa Salete, por um ano hidrológico, que permitirá estabelecer a influência das variações sazonais no comportamento hidrogeoquímico das águas dos aquíferos;

-coletar água para análise físico-química a diferentes profundidades e em diferentes regimes de bombeamento, na tentativa de definir perfis hidroquímicos e correlações com dados das amostras de sedimentos e rochas; 
-em estudo anterior e nesta pesquisa, notou-se que a origem do cromo pode estar relacionada diretamente aos sedimentos da Formação Adamantina, razão pela qual sugere-se novos estudos para melhor compreensão do fenômeno, inclusive as condições de mobilidade e transferência do cromo em águas do substrato;

-recomenda-se fazer um estudo interlaboratorial para comparações de metodologia de análise de cromo total e hexavalente. 
ALMEIDA, M. A. de; STEIN, D. P.; MELO, M. S. de; BISTRICHI, C.A; PONÇANO, W. L; HASUI, Y.; ALMEIDA F. F. M. de (1980). Geologia do oeste paulista e áreas fronteiriças dos Estados de Mato Grosso do Sul e Paraná. In: CONGRESSO BRASILEIRO DE GEOLOGIA, 31., Camboriú, 1980. Anais. Camboriú, SBG. v.5, p. 2799-2812.

AMARAL, R. (1985). Importância dos elementos essenciais em águas para consumo humano. In: CONGRESSO BRASILEIRO DE ENGENHARIA SANITÁRIA E AMBIENTAL, 13., Maceió, 1985. Anais. São Paulo, CETESB/ABES. $14 \mathrm{p}$.

BARTLETT, R. J.; KIMBLE, J. M. (1976). Behavior of chromium in soils: II. Hexavalent forms. Journal of Environmental Quality. American Society of Agronomy, v.5, p. 383-386.

BARTLETT, R. J.; JAMES, B. (1979). Behavior of chromium in soils: III. Oxidation. Journal of Environmental Quality. American Society of Agronomy, v.8, p. 31-35.

BRANDT NETO, M. (1977). Estratigrafia da Formação Bauru na Região do Baixo Tietê. São Paulo, 74 p. (Dissertação de Mestrado-Instituto de Geociências/USP). 
BRANDT NETO, M. (1984). O Grupo Bauru na Região Centro-Norte do Estado de São Paulo. São Paulo, 2v. (Tese de Doutoramento-Instituto de Geociências/USP).

BRANDT NETO, M.; PETRI, S.; COIMBRA, A. M. (1985). Argilominerais do Grupo Bauru: considerações genéticas. In:SIMPÓSIO REGIONAL DE GEOlOGIA, 5., São Paulo, 1985. Atas .São Paulo, SBG- Núcleo de São Paulo. v.1, p. 61-74.

BRASIL. COMPANHIA DE TECNOLOGIA DE SANEAMENTO AMBIENTAL (1977). Poluição das águas subterrâneas no Estado de São Paulo: estudo preliminar. São Paulo, CETESB. 88 p.

BRASIL. COMPANHIA DE TECNOLOGIA DE SANEAMENTO AMBIENTAL. (1994). Compilação de Padrões Ambientais. São Paulo, CETESB. 7 p.

BRASIL. DEPARTAMENTO DE ÁGUAS E ENERGIA ELÉTRICA (1976). Estudo de Águas Subterrâneas: Regiões Administrativas 7, 8 e 9 . São Paulo, DAEE. 4v.

BRASIL. DEPARTAMENTO DE ÁGUAS E ENERGIA ELÉTRICA (1988). Água subterrânea reserva estratégica. Águas e Energia Elétrica, v.5, n.13, p. 14-23.

CALDER, L. M. (1988). Chromium in Groundwater. In: NRIAGU, J.; NIEBOER, E. Chromium in the natural and human environments-advances in environmental science and technology. Ontario, John Wiley \& Sons. 31 p. 
CAMPOS, H. C. N. S. (1987). Contribuição do estudo hidrogeoquímico do Grupo Bauru no Estado de São Paulo. São Paulo, 158 p. (Dissertação de Mestrado-Instituto de Geociências/USP).

CAMPOS, H. C. N. S. (1993). Caracterização e cartografia das províncias hidrogeoquímicas do Estado de São Paulo. São Paulo, 177 p. (Tese de Doutoramento-Instituto de Geociências/USP).

CARRY, E. E.; ALLAWAY, W. H.; OLSON, O. E. (1977). Control of the chromium concentrations in food plants. 2. Chemistry of chromium in soils and its availability to plants. Journal of Agricultural and Food Chemistry, v. 25. p. 305-309.

COIMBRA, A. M. (1976). Arenitos da Formação Bauru: estudo de áreas-fonte. São Paulo, 2v. (Dissertação de Mestrado-Instituto de Geociências/USP).

DANA, J. D. (1986). Manual de Mineralogia. Rio de Janeiro, LTC. 642 p.

DURFOR, C.N. ; BECKER, E. (1964). Public water supplies of the 100 largest cities in the United States, 1962. U. S.Geological Survey Water Supply Paper, v. 1812, p. 1-364.

FREEZE, R. A.; CHERRY, J. A. (1979). Groundwater. Englewood Cliffs, Prentice-Hall. 604 p. 
HAGARTY, E. P.; GRUNINGER, R. M.; BALOG, G. G.; PATEL, M.A.; SOKHEY, A. S. (1991). Chromium- Contaminated Site Remediation for POTW Expansion. Water Environment \& Technology, v.3, n.4, p. 5357.

HEM, J. D. (1985) Study and interpretation of the chemical characteristics of natural water. U. S. Geological Survey Water Supply Paper, v.2254, p. 138-139.

HIRATA, R. ; RODOLFI, G. (1993). Presença de cromo nas águas subterrâneas em Urânia. São Paulo, Secretaria do Meio Ambiente/Instituto Geológico. 24 p. (Relatório Técnico).

INSTITUTO GEOGRÁFICO E CARTOGRÁFICO DO ESTADO DE SÃO PAULO. (1990). Plano cartográfico do Estado de São Paulo. São Paulo, IGC. Escala 1: 1.000.000.

INSTITUTO GEOGRÁFICO E GEOLÓGICO DE SÃO PAULO (1965). Folha topográfica de Santa Albertina: região sul do Brasil. São Paulo, IGGSP. Escala 1: 50.000 .

INSTITUTO DE PESQUISAS TECNOLÓGICAS (1981). Mapa geológico do Estado de São Paulo. São Paulo, IPT. v.1. Escala 1: 500.000.

KRAUSKOPF, K. B. (1979). Introduction to geochemistry. 2. ed. Tokyo, McGraw-Hill Kogakusha. p. 544-546. 
LOVE, S. K. (1967). Quality of surface waters of the United States 1963. Parts 1 and 2. North Atlantic Slope and South Atlantic Slope and Eastern Gulf of México Basins. U. S. Geological Survey Water Supply Paper. p.15.

MAHAN, B.H. (1972). Metais de transição. In:_.Química: um curso universitário. São Paulo, Edgard Blucher. p. 517-519.

MASON, B. H. (1971). Princípios de Geoquímica. São Paulo, EDUSP. 403 p.

MERTZ, W. A. (1969) Chromium occurence and function in biological systems. Physiological Reviews, v. 49, p. 163-239.

MIGLIORINI, R. B. (1994). Cemitérios como fonte de poluição em aquíferos. Estudo do Cemitério de Vila Formosa na Bacia Sedimentar de São Paulo. São Paulo. 74 p. (Dissertação de Mestrado-Instituto de Geociências/USP).

OHLWEILER, O. A. (1973). Grupo periódico VI a. In: .Química Inorgânica. São Paulo, Edgard Blucher. v. 2, p.537-556.

PAULING, L. (1966). Cromo, manganês e outros metais correlatos. In:_.Química geral. Rio de Janeiro, Sedegra. p. 564-570.

PICCIRILLO, E. M. ; MELFI, A. J. (1988). The mesozoic flood volcanism of the Paraná Basin: petrogenetic and geophysical aspects. São Paulo, Universidade de São Paulo/IAG. 600 p. 
ROBERTSON, F. N. (1975). Hexavalent Chromium in the ground water in Paradise Valley, Arizona. Ground Water, v.13, n.6, p. 516-527.

ROCHA, G. A. ; GIANCURSI, F. D.; PERRONI, J. C. A.; SOBREIRO NETO, A. F.; BERTACHINI, A. C.; CORREA, W. A. G.; CAMPOS, H. C. N. S.; DIOGO, A.; ROSA, R. B. G. S.; CASTRO, C. G. J. (1979). Hidrogeologia das bacias dos rios Aguapeí, Peixe e Paranapanema no Estado de São Paulo. In: SIMPÓSIO REGIONAL DE GEOLOGIA, 2., Rio Claro, 1979. Atas. Rio Claro, SBG- Núcleo de São Paulo. p. 85-100.

RUEGG, N. R. (1975). Modelos de variação química na província basálticas do Brasil Meridional: características de teor, distribuição geográfica e diferenciação. São Paulo, v.1 (Tese de Livre-docência- Instituto de Geociências/USP).

SETZER ,J.; PORTO, R. L. L. (1979). Tentativa da avaliação de escoamento superficial de acordo com o solo e o seu recobrimento vegetal nas condições do Estado de São Paulo. Boletim técnico-DAEE, v.12, n.2, p. 82-135.

SILVA, R. B. ; DEL MONTE, E. (1987). Mineralizações de Trona na Bacia do Paraná: uma possibilidade. Brasil Mineral - Engenho e Arte (Edição especial- Prêmio Nordburg de Pesquisa e Exploração Mineral). p. 24-34.

SOARES, P. C.; LANDIM, P. M. B.; FÚLFARO, V. J.; SOBREIRO NETO,A. F. (1980). Ensaios de caracterização estratigráfica do Cretácio no Estado de São Paulo: Grupo Bauru. Revista Brasileira de Geociências, v.10, n.3, p. 177-185. 
SOARES, J. A. (1992). Uma contribuição ao estudo do ciclo geoquímico dos metais pesados no ambiente marinho: determinação das concentrações de cromo total em sedimentos marinhos, provenientes da Enseada do Flamengo (S.P.) e Saco do Mamanguá (R.J.), por meio de ICP-AES e AAS. São Paulo, 139 p. (Dissertação de Mestrado-Instituto Oceanográfico/USP).

SOUZA, H. B. de; DERISIO, J. C. (1977). Guia Técnico de Coleta de Amostras. São Paulo. Companhia de Tecnologia de Saneamento Ambiental. 257 p.

STAMER, J. K. ; YORKE, T. H. : PEDERSON, G. L. (1985) Distribution and transport of trace substances in the Schuylkill River Basin from Berne to Philadelphia, Pennsylvania. U. S. Geological Water Supply Paper, v.2256-A, p. 14-19.

STUMM, W. \& MORGAN, J.J. (1981). Aquatic chemistry. New York, John Wiley and Sons. 780 p.

SZIKSZAY, M. (1981). Hidrogeologia das Fontes de Águas da Prata, Estado de São Paulo. São Paulo, 2v. (Tese de Livre -Docência-Instituto de Geociências/USP). 
Anexo 01: Cadastro de poços tubulares da região noroeste do Estado de São Paulo

\begin{tabular}{|c|c|c|c|c|c|c|c|c|c|c|}
\hline $\mathrm{N}^{0}$ & Localidade & $\begin{array}{l}\text { Poço } \\
\text { local }\end{array}$ & $\begin{array}{l}\text { Poço } \\
\text { SABESP }\end{array}$ & $\begin{array}{l}\text { Poço } \\
\text { DAEE }\end{array}$ & $\begin{array}{l}\text { Coordenadas } \\
\text { N-S/E-W }\end{array}$ & $\begin{array}{l}\text { Cota } \\
(m)\end{array}$ & \begin{tabular}{|l} 
Profund. \\
$(\mathrm{m})$
\end{tabular} & $\begin{array}{l}\text { Nivel } \\
\text { estát.(m) }\end{array}$ & $\begin{array}{l}\text { Nivel } \\
\operatorname{dinám}(m)\end{array}$ & $\begin{array}{l}\text { Vazæå } \\
\left(\mathrm{m}^{3} / \mathrm{h}\right)\end{array}$ \\
\hline 1 & Álvares Florence & $P 1$ & 23 & & $7752,50 / 614,50$ & 406 & 154 & 4,3 & 21,9 & 48 \\
\hline & & & & & & & & & & \\
\hline 2 & Aparecida D' Oeste & P 1 & & & $7738,80 / 512,45$ & 400 & 156 & 32 & 105 & 13,5 \\
\hline & & & & & & & & & & \\
\hline 3 & Arabá & $\mathbf{P 1}$ & & & $780185 / 562,35$ & 415 & 120 & 1,3 & 34,51 & 45 \\
\hline & & & & & & & & & & \\
\hline 4 & Aspásia & $\mathrm{P1}$ & 815 & & $7770 / 527,6$ & 380 & 220 & 53 & 62,82 & 46,58 \\
\hline & & & & & & & & & & \\
\hline 4 & & $\mathrm{P2}$ & 816 & & $7767,6 / 527,85$ & 420 & 81 & 14,39 & 61,2 & 4,5 \\
\hline & & & & & & & & & & \\
\hline 4 & & P3 & 849 & & $7771,5 / 528,40$ & 410 & 72 & 11,84 & 63,82 & 10,5 \\
\hline & & & & & & & & & & \\
\hline 5 & Auriflama & $\mathbf{P} 2$ & 72 & & $7713 / 546,8$ & 465 & 120 & 10,9 & 46 & 5,4 \\
\hline & & & & & & & & & & \\
\hline 5 & & P 3 & 73 & & $7713 / 546,9$ & 465 & 123 & 12 & 42 & 7,5 \\
\hline & & & & & & & & & & \\
\hline 5 & & $P 6$ & 76 & & $7713,3 / 546,4$ & 440 & 171 & & & \\
\hline & & & & & & & & & & \\
\hline 5 & & $P 7$ & 77 & & $7713,5 / 546,4$ & 440 & 98 & 2 & 34,6 & 7 \\
\hline & & & & & & & & & & \\
\hline 5 & & $P 10$ & 80 & & $7713,7 / 546,4$ & 430 & 160 & 11,5 & 132,13 & 5 \\
\hline & & & & & & & & & & \\
\hline 5 & & P 11 & 81 & & $7714 / 545,8$ & 420 & 164,5 & 6,59 & 114,37 & 7,68 \\
\hline & & & & & & & & & & \\
\hline 5 & & $\mathbf{P} 12$ & 878 & & $7710 / 547,10$ & 390 & 251 & 45,96 & 108,9 & 30 \\
\hline & & & & & & & & & & \\
\hline 6 & Bandeirante $\mathrm{D}^{\prime}$ Oeste & $P_{2}$ & 942 & & $7721,2 / 519,5$ & 370 & 179 & 37,44 & 119,02 & \\
\hline & & & & & & 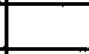 & & & & \\
\hline 7 & Boa Vista dos Andradas & $P 1$ & 24 & & $7765,9 / 617,2$ & 450 & 200 & 52,16 & & 7,2 \\
\hline & & & & & & & & & & \\
\hline 8 & Cardoso & $\mathrm{P} 1$ & 160 & & $7779,07 / 612,70$ & 390 & 145 & 4,7 & 50 & 18 \\
\hline & & & & & & & & & & \\
\hline 9 & Dalas & $\mathrm{P1}$ & & SF22DIII2-30 & $7731,2 / 527,5$ & 360 & 105,5 & 5,7 & 105,1 & 7 \\
\hline & & & & & & & & & & \\
\hline 10 & Dirce Reis & P1 & 651 & & $7737,1 / 541,1$ & 400 & 110,2 & 20,5 & 77,5 & 14,14 \\
\hline & & & & & & & & & & \\
\hline 10 & & P 2 & 1013 & & $7736,80 / 541$ & 400 & 101,46 & 26 & 71,75 & 12 \\
\hline & & & & & & & & & & \\
\hline 11 & Dolcinopolis & P1 & & & $7774,75 / 550,3$ & 435 & 80 & 14,8 & 33,2 & 22 \\
\hline 11 & & P3 & 1321 & & $7774,45 / 553,15$ & 430 & 176 & 8,3 & 64,32 & 39,6 \\
\hline & & & & & & & & & & \\
\hline 12 & Dulcelina & $\mathrm{P} 1$ & 1026 & & $7764,45 / 584,75$ & 495 & 113,2 & 11,38 & 41,88 & 10 \\
\hline & & & & & & & & & & \\
\hline 13 & Esmeralda & P & 598 & & $7755,35 / 495,3$ & 340 & 150 & 0,8 & 21,64 & 5 \\
\hline & & & & & & & & & & \\
\hline
\end{tabular}




\begin{tabular}{|c|c|c|c|c|c|c|c|}
\hline $\begin{array}{l}\text { Nol } \\
\text { Poço }\end{array}$ & Geologia & \begin{tabular}{|l|} 
Filtros \\
de-até $(m)$
\end{tabular} & $\begin{array}{l}\begin{array}{l}\text { Cimentação } \\
\text { de-até }(\mathrm{m})\end{array} \\
\end{array}$ & $\begin{array}{l}\text { Ano de } \\
\text { perfur. }\end{array}$ & Uso da água & Firma Perf. & Referéncia \\
\hline \multirow[t]{2}{*}{$1 / \mathrm{P} 1$} & 0.5,4 G. Bauru & & & 1974 & expioraçăăo & & Junto a elevatória \\
\hline & 5,4-154 S.Geral & & & & & & \\
\hline \multirow[t]{2}{*}{$2 / \mathrm{P}_{1}$} & & & & 1972 & exploraçảo & & \\
\hline & & & & & & & \\
\hline \multirow[t]{2}{*}{$3 / \mathrm{P} 1$} & 0-6 G.Bauru & & $0-36,6$ & 1980 & exploraçăo & Waldemar Georg. & Margem do Córrego \\
\hline & 6-120 S.Geral & & & & & e Cia. Ltda & das Pedras \\
\hline \multirow[t]{2}{*}{$4 / \mathrm{P}$} & 0-26 G. Bauru & & $0-31,00$ & 1979 & exploraçăo & Waldemar Georg. & \\
\hline & 26-220 S. Geral & & & & & e Cia. Ltda & \\
\hline \multirow[t]{2}{*}{$4 / \mathrm{P}^{2}$} & $0-80,4$ G. Bauru & $63,87-$ & $\longdiv { 0 - 6 , 0 0 }$ & 1981 & exploraçāo & Rafael F. Politi & Próximo ao Córrego da \\
\hline & $80,4-81$ S. Geral & 79,87 & & & & Eng. Const. Ltda & Anta \\
\hline \multirow[t]{2}{*}{$4 / \mathrm{P} 3$} & 0-62 G.Bauru & $21,31-$ & $0-18,00$ & 1982 & exploraçăo & Waldemar Georg. & Junto ao reservatório \\
\hline & 62-72 S.Geral & 65,81 & & & & o Cia Lida. & \\
\hline \multirow[t]{2}{*}{$5 / \mathrm{P} 2$} & 0-120 G.Bauru & & & 1963 & expl.(possui 90m & J. Passarelli & R. Jaboticabal \\
\hline & & & & & de prof. desmor.) & & \\
\hline \multirow[t]{2}{*}{$5 / \mathrm{P} 3$} & 0-123 G. Bauru & & & & exploração & J. Passarelli & R. Jaboticabal \\
\hline & & & & & & & \\
\hline \multirow[t]{2}{*}{$5 / \mathrm{P} 6$} & O-123 G.Bauru & & & $\begin{array}{l}19681 \\
69\end{array}$ & exploraçăo & Dr. Aquino(Jales) & Propriedade de Joăo \\
\hline & 123-171 S.Geral & & & & & & Marcolino \\
\hline \multirow[t]{2}{*}{$5 / P_{7}$} & 0-98 G.Bauru & & & 1971 & exploração & G. Ubaldine & Atrás do Matadouro \\
\hline & & & & & & & \\
\hline \multirow[t]{2}{*}{$5 / \mathrm{P} 10$} & $0-158$ G.Bauru & 29,94 & & 1981 & exploração & J. Passarelli & Junto ao reservatório \\
\hline & 158-160 S.Geral & 142,38 & & & & & \\
\hline \multirow[t]{2}{*}{$5 / \mathrm{P} 11$} & $0-146$ G.Bauru & $32,73-$ & $0-18,00$ & 1982 & exploraçãa & J. Passarelli & Margens do Córrego \\
\hline & 146-164,5 S.Geral & 140 & & & & & Limoeiro \\
\hline \multirow[t]{2}{*}{$5 / P_{12}$} & $0-134$ G.Bauru & & $0-18,20$ & 1982 & exploração & J. Passarelli & Na saida para Major \\
\hline & 134-251 S.Geral & & & & & & Prado \\
\hline \multirow[t]{2}{*}{$6 / P_{2}$} & 0-178,5 G.Bauru & $66,77-$ & $0-12,00$ & 1985 & exploraçăo & Passarelli & Próximo ao reservatório \\
\hline & 178,5-179 S.Geral & 144,05 & & & & & elevado \\
\hline \multirow[t]{2}{*}{$7 / \mathrm{P} 1$} & 0-30 G.Bauru & & & 1972 & exploração & & Próximo ao reservatório \\
\hline & 30-200 S.Geral & & & & & & \\
\hline \multirow[t]{2}{*}{ 8/P 1} & 0.145 S.Geral & & & 1954 & exploração & Pamec & R. Dr. Luiz de Barros \\
\hline & & & & & & & Lessa, junto ao ETA \\
\hline \multirow[t]{2}{*}{ 9/P 1} & 0-96 G.Bauru & & $0-22,50$ & 1980 & exploração & Hidrotécnica Serv. & As margens do Córrego \\
\hline & $96-105,5$ S.Geral & & & & & Geol. Ltda. & do Corvo o/ a estr. munic. \\
\hline \multirow[t]{2}{*}{$10 / \mathrm{P} 1$} & $0-101,2$ G. Bauru & 33,9 & $0-15,00$ & 1978 & exploraçảo & J. Passarelli & Atrás da Escola Est. de \\
\hline & $101,2-110,2$ S.Geral & 98,1 & & & & & 1 Grau de Dirco Reis \\
\hline \multirow[t]{2}{*}{$10 / \mathrm{P} 2$} & 0-100 G.Bauru & 46,95 & $0-10,00$ & 1986 & exploração & Air-Drill Ind. e Com. & Ao lado do reservatório \\
\hline & 100-101,46 S.Geral & 98 & & & & Ltda & da SABESP \\
\hline \multicolumn{8}{|c|}{\begin{tabular}{|l|l|}
$11 / \mathrm{P} 1$ & \\
$11 / 2$ & \\
\end{tabular}} \\
\hline \multirow[t]{2}{*}{$11 / \mathrm{P}^{3}$} & 0-64 G. Bauru & & $0-17,30$ & 1992 & exploraçăo & Air-Drill & Margem esquerda do \\
\hline & 64-176 S.Geral & & & & & & Córrego Arrancado \\
\hline \multirow[t]{2}{*}{$12 / \mathrm{P} 1$} & 0-113 G.Bauru & $27,77-$ & & 1987 & exploraçăo & Constroli Proj. $\theta$ & Esquinas das ruas \\
\hline & 113-113,2 S.Geral & 86,46 & & & & Const. Ltda. & Brasil e Săo Joăo \\
\hline $13 / \mathrm{P}$ & 0-34 G.Bauru & $34,00-$ & $0-12,00$ & 1981 & exploraçăo & Hidrogesp & Próximo à lgreja \\
\hline & 34-150 S.Geral & 39 & & & & & \\
\hline
\end{tabular}




\begin{tabular}{|c|c|c|c|c|c|c|c|c|c|c|}
\hline 14 & Estrela D'Oeste & P5 & 211 & & $77754,8 / 562,25$ & 430 & 201 & T12 & 38,65 & 40 \\
\hline & & & & & & & & & & \\
\hline \multirow[t]{2}{*}{14} & & P6 & & & $7753,60 / 561,77$ & 430 & 196 & 23,76 & 48,74 & 40 \\
\hline & & & & & & & & & & \\
\hline \multirow[t]{2}{*}{14} & & $\mathrm{P} 7$ & 213 & & $7754,3 / 562,10$ & 430 & 202 & 11,7 & 90,43 & 60 \\
\hline & & & & & & & & & & \\
\hline \multirow[t]{2}{*}{15} & Fátima Paulista & $P 1$ & 805 & & $7777,25 / 556,85$ & 435 & 220 & 3,35 & 115,92 & 8,4 \\
\hline & & & & & & & & & & \\
\hline \multirow[t]{3}{*}{16} & Fernandópolis & $P 15$ & & $220114-45$ & $7758,40 / 583,15$ & 441 & 1460 & 16,35 & 61,95 & 450 \\
\hline & & & & & & & & & & \\
\hline & & & & & & & & & & \\
\hline \multirow[t]{5}{*}{16} & & $\mathrm{P} 16$ & & 22D114-49 & $7757,1 / 581,2$ & 480 & 1683 & 31,29 & 110,87 & 430 \\
\hline & & & & & & & & & & \\
\hline & & & & & & & & & & \\
\hline & & & & & & & & & & \\
\hline & & & & & & & & & & \\
\hline \multirow[t]{4}{*}{16} & & $P 97$ & 1068 & & $7760,55 / 585,35$ & 436 & 1606 & 11,5 & 76 & 522,2 \\
\hline & & & & & & & & & & \\
\hline & & & & & & & & & & \\
\hline & & & & & & & & & & \\
\hline \multirow[t]{2}{*}{17} & Gastáo Vidigal & P5 & 879 & & $7698,8 / 585,3$ & 380 & 207 & 36,5 & 39,85 & 66 \\
\hline & & & & & & & & & & \\
\hline \multirow[t]{2}{*}{17} & & $P 6$ & 903 & & $7700,2 / 584,35$ & 420 & 85,15 & 22,78 & 66,67 & 3,9 \\
\hline & & & & & & 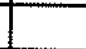 & & & & \\
\hline \multirow[t]{2}{*}{17} & & $P 7$ & 909 & & $7700,40 / 583,95$ & 435 & 88,5 & 13,08 & 58,76 & 3,6 \\
\hline & & & & & ( & & & & & \\
\hline \multirow[t]{2}{*}{18} & Guzolåndia & P2 & 970 & & $7785,80 / 533,25$ & 390 & 220 & 12,3 & 137 & 6 \\
\hline & & & & & & & & & & \\
\hline \multirow[t]{2}{*}{18} & & $\sqrt{P 3}$ & 1080 & & $7716,10 / 535,1$ & 460 & 211 & 34,8 & 135,92 & 15 \\
\hline & & & & & & & & & & \\
\hline \multirow[t]{2}{*}{19} & Ica Iolanda & $\overline{P_{1}}$ & & $22 \times A V 1-1-3$ & $7710,8 / 609,4$ & 530 & 171,7 & 29,9 & 129 & 14,7 \\
\hline & & & & & & & & & & \\
\hline \multirow[t]{2}{*}{20} & Indiaporả & $\mathrm{P}_{1}$ & 279 & & $7790,9 / 574,1$ & 435 & 88 & 51,11 & 67,11 & 35 \\
\hline & & & & & & & & & & \\
\hline \multirow[t]{2}{*}{20} & & $P 2$ & 280 & & $7790,00 / 573,30$ & 411 & 115 & 2 & 42 & 45 \\
\hline & & & & & & & & & & \\
\hline \multirow[t]{2}{*}{20} & & $\mathrm{P3}$ & 281 & & $7789,7 / 573,9$ & 414 & 123 & 37,49 & 61,49 & 55 \\
\hline & & & & & & & & & & \\
\hline \multirow[t]{2}{*}{20} & & $P 4$ & 282 & & $7789,95 / 573,4$ & 430 & 162 & 16,95 & 28,94 & 50 \\
\hline & & & & & & & & & & \\
\hline \multirow[t]{2}{*}{20} & & $\mathrm{P5}$ & 283 & & $7780,9 / 573,7$ & 427 & 112 & 50,81 & 68,81 & 60 \\
\hline & & & & & & & & & & \\
\hline \multirow[t]{2}{*}{21} & Jales & $\mathrm{P} 1=$ & 326 & & $7756,90 / 546,10$ & 440 & 101 & 8,85 & 73,85 & 14 \\
\hline & & P 16 & & & & & & & & \\
\hline \multirow[t]{2}{*}{21} & & $P 2=$ & 327 & & $7757,10 / 546,30$ & 440 & 102 & 8,41 & 70,43 & 26,4 \\
\hline & & P 17 & & & & & & & & \\
\hline \multirow[t]{2}{*}{21} & & $P_{3}=$ & 328 & & $7757,50 / 546,55$ & 450 & 101 & 13,23 & 70,7 & 18 \\
\hline & & P 18 & & & & & & & & \\
\hline
\end{tabular}




\begin{tabular}{|c|c|c|c|c|c|c|c|}
\hline$\longdiv { 1 4 / P 5 }$ & $0-57,7$ G.Bauru & $39,75-$ & $0-9,00$ & 1981 & exploração & Copesrcal S.A. Ind. & Próximo ao Córrego \\
\hline & 57,7-201 S.Geral & 58,15 & & & & ecom. & Broaca \\
\hline \multirow[t]{2}{*}{$14 / \mathrm{P}$} & 0-61 G. Bauru & $45,05-$ & $0-10,00$ & 1981 & exploraçāo & Copercal-P.A. Ind. & Próximo ao Córrego \\
\hline & 61-196 S.Geral & 60,55 & & & & e Com. L.tda. & Broaca \\
\hline \multirow[t]{2}{*}{$14 / \mathrm{P} 7$} & 0-59 G.Bauru & & & 1981 & exploraçăo & Cia. T. Janer Com. & \\
\hline & 59-202 S. Geral & & & & & e lnd. & \\
\hline \multirow[t]{2}{*}{$15 / \mathrm{PA}_{1}$} & 0-54 G.Bauru & $40,05-$ & $0-3,00$ & 1979 & |exploraçăo & Passarelli & \\
\hline & 54-220 S.Geral & 57 & & & & & \\
\hline \multirow[t]{3}{*}{$16 / \mathrm{P} 15$} & 0-74,6 G.Bauru & 1288,80 & $0-74,60$ & 1976 & exploraçăo & Air-Lift Ind. \& Com. & $\mathrm{km}$ 4, estrada que liga \\
\hline & $74,6-1285$ S.Geral & 1428,98 & & & & Ltda. & Fernand. a Pedran. \\
\hline & 1285-1460 Botucatu & & & & & & \\
\hline \multirow{5}{*}{ 16/P16 } & $0-130$ G.Bauru & 1179,14 & $0-132,00$ & 1981 & exploração & CPRM & Margem do Córrego \\
\hline & 130-1337 S.Geral & 1651,82 & & & & & Gatåo \\
\hline & 1337-1480 Botucatu & & & & & & \\
\hline & 1480-1645 Pirambóia & & & & & & \\
\hline & 1645-1683 Estr.Nova & & & & & & \\
\hline \multirow[t]{4}{*}{$16 / \mathrm{P} 17$} & $0-130$ G.Bauru & $1166,74-$ & $0-130,00$ & 1987 & exploraçäo & CPRM & Margem esquerda do \\
\hline & $130-1320$ S.Geral & 1408,27 & & & & & Córrego da Aldeia \\
\hline & $1320-1670-B o t /$ Piram. & & & & & & \\
\hline & 174-180 S.Geral & & & & & & \\
\hline \multirow[t]{2}{*}{$17 / \mathrm{P} 5$} & 0-28 G.Bauru & $20-26$ & $0-13,36$ & 1980 & exploraçăo & Passarelli & \\
\hline & 28-207 S.Geral & & & & & & \\
\hline \multirow[t]{2}{*}{$17 / P_{6}$} & a-84 G.Bauru & 38,17 & $0-12,00$ & 1984 & exploração & Copersul Pç. Artes. & Ao lado do reservatório \\
\hline & $84-85,15$ S.Geral & 77,99 & & & & Litda. & da SABESP \\
\hline \multirow[t]{2}{*}{$17 / \mathrm{P} 7$} & $0-87$ G.Bauru & 64 & $0-12,00$ & 1984 & exploraçáa & Copersul & Próximo à saida da \\
\hline & $87-88,5$ S.Geral & 82,98 & & & & & cidade \\
\hline \multirow[t]{2}{*}{$18 / \mathrm{P} 2$} & 0-145 G.Bauru & & $0-16,00$ & 1985 & exploraçãa & Passarelii & Próximo ao Matadouro \\
\hline & 145-220 S.Geral & & & & & & Municipal \\
\hline \multirow[t]{2}{*}{$18 / \mathrm{P} 3$} & 0-208 G.Bauru & 115,14 & $0-18,00$ & 1988 & exploração & Passarelli & F. Top IBGE no 50 \\
\hline & 208-211 S.Geral & 183,18 & & & & & \\
\hline \multirow[t]{2}{*}{ 19/P 1} & 0-156 G.Bauru & $44,8-$ & $0-25,00$ & 1979 & exploraçåo & Passarelli & Junto ao reservatório \\
\hline & 156-171,7 S.Geral & 153 & & & & & da SABESP \\
\hline \multirow[t]{2}{*}{$20 / P_{1}$} & 0-12 G.Bauru & & $0-12,00$ & 1973 & exploraçăo & Geo Pesquisadora & \\
\hline & 12-88 S.Geral & & & & & & \\
\hline \multirow[t]{2}{*}{$20 / \mathrm{P}^{2}$} & 0-15 G.Bauru & & $0-19,00$ & 1975 & exploraçăo & Air Lift & \\
\hline & 15-115 S.Geral & & & & & & \\
\hline \multirow[t]{2}{*}{$20 / \mathrm{P}^{3}$} & 0-18,5 G.Bauru & & $0-18,50$ & 1975 & exploraçăo & Air Lift & Lado direito da estrada \\
\hline & 18,5-123 S.Geral & & & & & & municipal ind. Macedón. \\
\hline \multirow[t]{2}{*}{$20 / P^{4}$} & $0-19,5$ G.Bauru & & & 1972 & exploração & Passarelli & \\
\hline & 19,5-162 S.Geral & & & & & & \\
\hline \multirow[t]{2}{*}{$20 / \mathrm{P} 5$} & 0-19 G.Bauru & & $0-19,00$ & 1975 & exploraçăa & Air Lift & \\
\hline & 19-112 S.Geral & & & & & & \\
\hline \multirow[t]{2}{*}{$21 / \mathrm{P} 1$} & 0-96 G.Bauru & $54,34-$ & $0-15,00$ & 1980 & exploração & Hidrogesp & Bateria de poços \\
\hline & 96-101 S.Geral & 95,88 & & & & & \\
\hline \multirow[t]{2}{*}{$21 / \mathrm{P} 2$} & 0-96 G.Bauru & 43,87 & $0-15,00$ & 1980 & exploraçăo & Hidrogesp & As margens do Córrego \\
\hline & 96-102 S.Geral & $\overline{94,76}$ & & & & & Marimbondo \\
\hline \multirow[t]{2}{*}{$21 / P_{3}$} & $0-100,5$ G.Bauru & $47,55-$ & $0-15,00$ & 1980 & exploraçăo & Hidrogesp & \\
\hline & 100,5-101 S.Geral & 92 & & & & & \\
\hline
\end{tabular}




\begin{tabular}{|c|c|c|c|c|c|c|c|c|c|c|}
\hline 21 & & $P_{4}=$ & 329 & & $7759,05 / 547,60$ & 460 & 145,32 & 19,38 & 84,92 & 35 \\
\hline & & P 19 & & & & & & & & \\
\hline \multirow[t]{3}{*}{21} & & P21 & 1311 & & $7756,6 / 548,8$ & 430 & 1205 & 15 & 60,5 & 500 \\
\hline & & (Porç. & & & & & & & & \\
\hline & & ii) & & & & & & & & \\
\hline 22 & Macedónia & P1 & & & & & 17 & jorrante & 56,3 & 20 \\
\hline \multirow[t]{2}{*}{22} & & $\mathbf{P 2}$ & 391 & & $7772,8 / 584$ & 490 & 156,63 & 12,1 & 120,41 & 6 \\
\hline & & & & & & & & & & \\
\hline \multirow[t]{2}{*}{22} & & $\mathrm{P3}$ & 907 & & $7771,3 / 583,99$ & 510 & 178 & 21,88 & 112,08 & 12 \\
\hline & & & & & & & & & & \\
\hline \multirow[t]{2}{*}{23} & Mangaratu & $\mathrm{P} 1$ & 835 & & $7740,05 / 674,05$ & 470 & 84,49 & jorrante & 74 & 10 \\
\hline & & & & & & & & & & \\
\hline \multirow[t]{2}{*}{24} & Marinópolis & $\mathrm{P2}$ & 1171 & & $7739,80 / 518,45$ & 405 & 156 & 14,6 & 107,16 & 14,14 \\
\hline & & & & & & & & & & \\
\hline \multirow[t]{2}{*}{24} & & $\mathrm{P3}$ & 1256 & & $7739,20 / 519,30$ & 375 & 250 & 13,63 & 136,92 & 7,33 \\
\hline & & & & & & & & & & \\
\hline \multirow[t]{2}{*}{24} & & $P 4$ & 1318 & & $7738,30 / 519,90$ & 360 & 230 & 19,58 & 118,61 & 29 \\
\hline & & & & & & & & 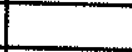 & & \\
\hline \multirow[t]{2}{*}{25} & Meśbolis & p1 & & SF22VIII4-05 & $7795,1 / 539,4$ & 380 & 200 & jorrante & 27 & 60 \\
\hline & & & & & & 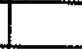 & & & & \\
\hline \multirow[t]{2}{*}{26} & Mira Estrela & $P_{1}$ & & & & 430 & 212 & 61,3 & 183 & \\
\hline & & & & & & 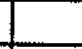 & & & & \\
\hline \multirow[t]{2}{*}{26} & & $P 4$ & 406 & & $7790,05 / 542,85$ & 380 & 143 & 3,48 & 94,6 & 9 \\
\hline & & & & & & & & & & \\
\hline \multirow[t]{2}{*}{26} & & P5 & 407 & & $7790,10 / 596,6$ & 390 & 150 & 6,73 & 100,4 & \\
\hline & & & & & & & & & & \\
\hline \multirow[t]{2}{*}{26} & & $P 6$ & 910 & & $7790,90 / 594,10$ & 380 & 180 & 5,59 & 112,43 & 4,8 \\
\hline & & & & & & & & & & \\
\hline \multirow[t]{2}{*}{26} & & $\mathrm{P} 7$ & 1038 & & $7790,90 / 594 / 10$ & 360 & 182 & 2,8 & 66,87 & \\
\hline & & & & & & & & & & \\
\hline \multirow[t]{2}{*}{27} & Monçб̄es & $P 1$ & 416 & & $7694,40 / 594,75$ & 430 & 203. & 67 & 150 & 12,9 \\
\hline & & & & & & & & & & \\
\hline \multirow[t]{2}{*}{27} & & $P 3$ & 418 & & $7696,30 / 592,70$ & 390 & 144 & 18,57 & 91,12 & \\
\hline & & & & & & & & & & \\
\hline \multirow[t]{2}{*}{28} & Nova Lusitấnia & $P 4$ & 889 & & $7693,2 / 576,50$ & 460 & 95 & 40,2 & 90,1 & \\
\hline & & & & & & & & & & \\
\hline \multirow[t]{2}{*}{28} & & P5 & 1128 & & $7693,05 / 575,85$ & 430 & 100 & 8,58 & 77,41 & \\
\hline & & & & & & & & & & \\
\hline \multirow[t]{2}{*}{28} & & P6 & 1238 & & $7695,80 / 577,25$ & 360 & 230 & 3,53 & 98,98 & \\
\hline & & & & & & & & & & \\
\hline 29 & Palmeira $D^{\prime}$ Oeste & P1 & & & & & 109 & 15 & 90 & 3 \\
\hline 29 & & P2 & & & & & 10,5 & 20 & 80 & 4 \\
\hline \multirow[t]{2}{*}{29} & & P8 & 467 & & $7742,15 / 523,70$ & 369 & 205 & 30,57 & 101,86 & 9,77 \\
\hline & & & & & & & & & & \\
\hline \multirow[t]{2}{*}{29} & & P9 & 468 & & $7741,4 / 523,5$ & 390 & 201,5 & 0,73 & 93,83 & 12,3 \\
\hline & & & & & & & & & & \\
\hline 30 & Paranapuă & $\mathrm{P3}$ & & SF22D1-2-12 & $7777,1 / 540,2$ & 400 & 180 & 7,57 & 18,18 & 60 \\
\hline & & & & & & & & & & \\
\hline
\end{tabular}




\begin{tabular}{|c|c|c|c|c|c|c|c|}
\hline $21 / \mathrm{P}_{4}$ & 0-143 G.Bauru & $36,45-$ & $0-15,00$ & 1980 & exploração & Hidrogesp & Almoxarifado da Prefeit. \\
\hline & 143-145,32 S.Geral & 142,32 & & & & & \\
\hline \multirow[t]{3}{*}{ 21/P21 } & 0-85 G.Bauru & & $0-22,37$ & 1992 & exploraçäo & Contep & Margem direita do \\
\hline & 85-986 S.Geral & & & & & & Corrego Timburi \\
\hline & 986-1205 Botucatu & & & & & & \\
\hline \multirow{3}{*}{\begin{tabular}{|l|}
$22 / \mathrm{P} 1$ \\
$22 / \mathrm{P} 2$ \\
\end{tabular}} & Q-17 G.Bauru & & & & & & \\
\hline & $0-155,63$ G.Bauru & $46,82-$ & $0-22,00$ & 1981 & exploraçăo & Passarelli & Junto à Lagoa de Estab. \\
\hline & 155,63-156,63 S.Geral & 111,7 & & & & & do Capituva \\
\hline \multirow[t]{2}{*}{$22 / P_{3}$} & $0-172$ G.Bauru & $55,19-$ & $0-12,00$ & 1984 & exploraçăo & Passarelli & Chácara Santa Rita \\
\hline & 172-178 S.Geral & 145,78 & & & & & \\
\hline \multirow[t]{2}{*}{$23 / \mathrm{P} 1$} & 0-84 G.Bauru & 20,08 & $0-12,00$ & 1982 & exploraçáo & Hidrogesp & Junto ao Córrego \\
\hline & 84-84,49 S.Geral & 79,45 & & & & & Mangaratu \\
\hline \multirow{2}{*}{$24 / \mathrm{P} 2$} & 0-154 G.Bauru & & $0-17,00$ & 1989 & exploraçăo & Air Drill & R. SåoPaulo,457 \\
\hline & 154-156 S.Geral & & & & & & \\
\hline \multirow[t]{2}{*}{$24 / \mathrm{P}_{3}$} & $0-117,60$ G.Bauru & & $0-18,00$ & 1992 & exploração & Geoplan & Próximo ao Matadouro \\
\hline & $117,60-250$ S.Geral & & & & & & Municipal \\
\hline \multirow[t]{2}{*}{$24 / P^{4}$} & 0-119 G.Bauru & & $0-19,00$ & 1992 & exploração & Passareli & Margem direita do \\
\hline & 119-230 S.Geral & & & & & & Córrego Trós Barras \\
\hline \multirow[t]{2}{*}{$25 / \mathrm{P} 1$} & D-6 G.Bauru & & $0-8,00$ & 1980 & exploraçăo & Waldemar Geor. & As margens do Córrego \\
\hline & 6-200 S.Geral & & & & & e Cia. Ltda. & do Meio \\
\hline \multirow[t]{2}{*}{$26 / \mathrm{P} 1$} & 0-86 G.Bauru & & $0-10,50$ & 1974 & exploraçắo & Janer & Caboceira do Córrego \\
\hline & $86-212$ S.Geral & & & & & & Aroeira \\
\hline \multirow[t]{2}{*}{$26 / \mathrm{P} 4$} & 0-54 G. Bauru & $31,902-$ & $0-7,10$ & 1980 & exploraçáo & Hidrotécnica Serv. & Sítio Santo António \\
\hline & 54-143 S.Geral & 53,92 & & & & Geológicos & \\
\hline \multirow[t]{2}{*}{$26 / P 5$} & $0-66$ G.Bauru & $38,12-$ & $0-12,00$ & 1981 & exploração & Waldemar Geor. & Sítio Santo António \\
\hline & 66-150 S.Geral & 66,3 & & & & e Cia. Ltda. & \\
\hline \multirow[t]{2}{*}{$26 / P^{2}$} & 0-53 G.Bauru & $6-16,74$ & $0-12,00$ & 1984 & exploração & Passarelli & Terreno do Sr. Luiz \\
\hline & 53-180 S.Geral & & & & & & Ferreira da Silva \\
\hline \multirow[t]{2}{*}{$26 / P 7$} & $0-50$ G.Bauru & $35,00-$ & $0-6,40$ & 1987 & expioraçăo & Constroli-Proj. $\theta$ & Confluéncia do Córrego \\
\hline & 50-182 S.Geral & 49 & & & & Const. Ltda. & Taquari com Ouro Verde \\
\hline \multirow[t]{2}{*}{$27 / P_{1}$} & $0-68$ G.Bauru & & $0-15,00$ & 1974 & exploração & Janer & Próximo ao Matedouro \\
\hline & 68-203 S.Goral & & & & & & Municipal \\
\hline \multirow[t]{2}{*}{$27 / P^{3}$} & 0-1 G.Bauru & & $0-21,40$ & 1980 & exploraçāo & Passarelili & Córrego do Cachorro \\
\hline & 1-144 S.Geral & & & & & & \\
\hline \multirow[t]{2}{*}{$28 / P^{4}$} & 0-96 G.Bauru & $51,55-$ & $0-17,60$ & 1983 & exploraçāo & Politi & Salda para Vicentinópol. \\
\hline & $96-100,25$ S.Geral & 93 & & & & & \\
\hline \multirow[t]{2}{*}{$28 / P^{2}$} & 14-92 G.Bauru & $34,41-$ & $0-12,00$ & 1988 & exploraçăo & Passarelli & Terreno do Sr. Ernesto \\
\hline & 92-100 S.Geral & 92,24 & & & & & Cavalini Filho \\
\hline \multirow[t]{2}{*}{$28 / \mathrm{P} 6$} & 0-24 G.Bauru & & $0-17,30$ & 1991 & exploraçāo & Hidrogesp & Margem esquerda do \\
\hline & 24-230 S.Geral & & & & & & Ribeirăo Gabirobas \\
\hline $29 / \mathrm{P} 1$ & 0-109 G.Bauru & & $0-12,00$ & 1970 & exploraçăo & Passarelii & \\
\hline $29 / \mathrm{P} 2$ & $0-105$ G.Bauru & & $0-6,00$ & 1970 & exploraçāo & Passareili & \\
\hline \multirow[t]{2}{*}{$29 / P 8$} & 0 -128 G.Bauru & $30,98-$ & $0-11,00$ & 1979 & exploraçăo & Waldemar Georg. $\theta$ & Nascente do Córrego \\
\hline & 128-205 S.Geral & 110,99 & & & & Cia Ltda. & Laranjeiras \\
\hline \multirow[t]{2}{*}{$29 / \mathrm{P} 9$} & 0-120 G.Bauru & $29,88-$ & $0-18,00$ & 1979 & exploraçăo & Waldemar Georg. $\theta$ & Faz. de Francisco Felix \\
\hline & 120-201,5 S.Geral & 119 & & & & Cia Ltda. & Mendonça \\
\hline \multirow[t]{2}{*}{$30 / \mathrm{P3}$} & $0-180$ S.Geral & & $0-5,70$ & 1979 & exploraçáo & Waldemar Georg. $\theta$ & As margens do Córrego \\
\hline & & & & & & Cia Ltda. & do Ingá \\
\hline
\end{tabular}




\begin{tabular}{|c|c|c|c|c|c|c|c|c|c|c|}
\hline 31 & Pedranópolis & $\mathrm{P} 1$ & 480 & & $7760,85 / 593,95$ & 460 & 141 & 24,2 & 112,9 & 6,5 \\
\hline & & & & & & & & & & \\
\hline 31 & & P3 & 482 & & $7759,10 / 593,70$ & 430 & 150 & 2,19 & 1114,5 & 3 \\
\hline & & & & & & & & & & \\
\hline 31 & & P4 & 902 & & $7760,60 / 593,80$ & 430 & 139 & 12,64 & 108,13 & 3,96 \\
\hline & & & & & & & & & & \\
\hline 31 & & P5 & 943 & & $7760,90 / 593,80$ & 430 & 40 & 11,85 & 23,26 & 1,65 \\
\hline 31 & & P6 & 1037 & & $7761,10 / 592,50$ & 470 & 128 & 11,57 & 67,6 & 7 \\
\hline & & & & & & & & & & \\
\hline 32 & Pontalinda & $P 1$ & 331 & & $7739,65 / 550$ & 380 & 150 & 2,66 & 67,61 & 11,1 \\
\hline & & & & & & & & & & \\
\hline 32 & & $P 2$ & 332 & & $7739,90 / 549,25$ & 380 & 6 & 6,5 & 43,37 & 15 \\
\hline & & & & & & & & & & \\
\hline 32 & & $\mathrm{P3}$ & 33 & & $7739,05 / 550,25$ & 380 & 72,5 & jorrante & 57,88 & 14 \\
\hline & & & & & & & & & & \\
\hline 33 & Riolândia & P5 & 924 & & $7791,90 / 639,70$ & 400 & 220 & 62,2 & 114,03 & 1,5 \\
\hline 33 & & P6 & 975 & & $7788,45 / 639,15$ & 420 & 221 & 3,59 & 155,33 & 6 \\
\hline & & & & & & & & & & \\
\hline 34 & Rubinéia & $P 1$ & 597 & & & & 118 & 14 & 59 & 19,8 \\
\hline & & 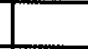 & & & & & & 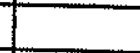 & & \\
\hline 35 & Santa Albertina & $\mathrm{P} 1$ & & & $7748,45 / 528,15$ & 405 & 220 & 4,7 & 131,27 & 9,2 \\
\hline & & & & & & & & & & \\
\hline 36 & Santa Clara D' Oeste & $P 1$ & & & & 370 & 120 & 24,92 & 11,18 & 12 \\
\hline & & & & & & & & & & \\
\hline 36 & & P2 & 846 & & $7778,9 / 507$ & 340 & 180 & 14,95 & 124,43 & 14,5 \\
\hline & & & & & & & & & & \\
\hline 37 & Sta. Isab. do Marinheiro & $\mathrm{P} 1$ & 483 & & $7770,45 / 596,20$ & 415 & 130,7 & 20,73 & & 30 \\
\hline & & & & & & & & & & \\
\hline 38 & Santa Salete & $\mathrm{P} 1$ & & & $7761,20 / 532,6$ & 435 & 130,45 & 29,45 & 106,15 & 16,5 \\
\hline & & & & & & & & & & \\
\hline 39 & Santana da Ponte Pensa & $P 1$ & & & & & 120 & 10,2 & 86,74 & 4 \\
\hline & & & & & & & & & & \\
\hline 39 & & $P_{3}$ & 627 & & $7760,55 / 522,13$ & 410 & 220 & 44,44 & 119,41 & 13 \\
\hline & & & & & & & & & & \\
\hline 40 & Săo Francisco & $\mathrm{P} 1$ & & & $7748,57 / 531,60$ & 408 & 150 & 18,4 & 119,36 & 18,73 \\
\hline & & & & & & & & & & \\
\hline 40 & & $P_{2}$ & & & $7749,15 / 532,10$ & 420 & 144,24 & 42,6 & 106,1 & 15 \\
\hline & & & & & & & & & & \\
\hline 41 & São Joåo das Duas Pontes & $\mathrm{Pt}$ & 652 & & $7745,30 / 564,55$ & 430 & 120 & 5,6 & 79,5 & 9,7 \\
\hline & & & & & & & & & & \\
\hline 41 & & P2 & 653 & & $7745,55 / 564,9$ & 420 & 120 & 20,87 & 80 & 8,5 \\
\hline 41 & & P3 & 1040 & & $7744,25 / 565,20$ & 395 & 221 & 13,37 & 101,73 & 8 \\
\hline & & & & & & & & & & \\
\hline 42 & Sáo Joăo do Marinheiro & $\overline{P 2}$ & & SF22DII-2-7 & $7786,5 / 600,2$ & 395 & 160,6 & 5,4 & 99,95 & \\
\hline & & & & & & & & & & \\
\hline 43 & Sebastianópolis do Sul & $\mathrm{P3}$ & 933 & & $7715,90 / 612,60$ & 460 & 180,5 & 62,37 & 68,62 & 30 \\
\hline & & & & & & & & & & \\
\hline 44 & Socimbra & $P 1$ & 938 & & $7747,75 / 511,00$ & 375 & 96 & 18,83 & 53,25 & 40 \\
\hline & & & & & & & & & & \\
\hline
\end{tabular}




\begin{tabular}{|c|c|c|c|c|c|c|c|}
\hline $31 / \mathrm{P}_{1}$ & & & & & & & \\
\hline & & & & & & & \\
\hline \multirow[t]{2}{*}{$31 / \mathrm{P} 3$} & 0-83,7 G.Bauru & $50,36-$ & $0-10,20$ & 1980 & exploração & Hidrotécnica Serv. & Margens do Córrego \\
\hline & $83,7-150$ S.Geral & 80,35 & & & & Geol. Ltda. & Forte \\
\hline \multirow[t]{2}{*}{$31 / P^{4}$} & 0-134 G. Bauru & 73,59 & $0-18,20$ & 1984 & exploração & Copersul- Pç. Artes. & Terreno de Ailton \\
\hline & 134-139 S.Geral & 126,56 & & & & Ltda. & Montovani \\
\hline $31 / \mathrm{P} 5$ & $0-40$ G.Bauru & $7,5-27$ & $0.2,0 \mathrm{C}$ & 1985 & exploraçăo & Passarelli & Ao lado de P 4 \\
\hline \multirow{2}{*}{$31 / P^{6} 6$} & 0-127,5 G.Bauru & 30,33 & $0-12,00$ & 1987 & Exploraçăo & Constroli-Proj.e & R. S. Pedro, próximo ao \\
\hline & $127,5-128$ S.Geral & 102,12 & & & & Const. Ltda. & cemitério \\
\hline \multirow[t]{2}{*}{$32 / \mathrm{P} 1$} & $0-80$ G.Bauru & 39,23 & $0-20,00$ & 1979 & exploraçåa & Waldemar Georg. & \\
\hline & 80 -150 S.Geral & 81,34 & & & & e Cia Ltda. & \\
\hline \multirow{2}{*}{$32 / \mathrm{P} 2$} & 0-65,3 G.Bauru & $35,98-$ & $0-13,4$ & 1980 & exploraçăo & Hidrotécnica & \\
\hline & 65,3-66,5 S.Geral & 59 & & & & & \\
\hline \multirow[t]{2}{*}{$32 / \mathrm{P}^{3}$} & 0-72 G.Bauru & 41,30 & $0-12,00$ & 1980 & exploraçāo & Waldemar Georg. & Margem do Corrego \\
\hline & 72-72,5 S.Geral & 64,25 & & & & $\theta$ Cia Ltda. & Lageado \\
\hline $33 / \mathrm{P5}$ & $0-220$ s.Geral & & $0-10,00$ & 1985 & inexplorável & Passarelli & \\
\hline \multirow[t]{2}{*}{$33 / \mathrm{P} 6^{-}$} & 0-221 S.Geral & & $0-8,30$ & 1986 & exploraçåo & Politi & Confluéncia dos Córreg. \\
\hline & & & & & & & Bálsamo e Antas \\
\hline \multicolumn{8}{|l|}{$34 / \mathrm{P} 1$} \\
\hline & & & & & & & \\
\hline \multirow{2}{*}{$35 / P 1$} & 0-62 G.Bauru & & $0-13,00$ & 1974 & exploraçäo & Janer & \\
\hline & 62-220 S.Geral & & & & & & \\
\hline \multirow[t]{2}{*}{$36 / P 1$} & 0-18 G.Bauru & & $0-13,00$ & 1975 & exploraçāo & Janer & Próximo ao Córrego da \\
\hline & 18-120 S.Geral & & & & & & Lontra com a estrada 9 \\
\hline \multirow[t]{2}{*}{$36 / P 2$} & 0-16,35 G.Bauru & & $0-20,00$ & 1982 & exploração & Janer & \\
\hline & 16,35-180 S.Geral & & & & & & \\
\hline \multirow[t]{2}{*}{$37 / \mathrm{P}_{1}$} & 0-130,7 S.Geral & & $0-10,00$ & 1980 & exploraçāo & Hidrotécnica Serv. & \\
\hline & & & & & & Geol.Ltda. & \\
\hline \multirow[t]{2}{*}{$38 / \mathrm{P}$} & 0-122,91 G.Bauru & 34,86 & $0-15,00$ & 1979 & exploraçăo & Waldemar Georg. & \\
\hline & 122,91- $\mid 30,45$ S.Geral & 109,97 & & & & e Cia L.tda. & \\
\hline \multirow[t]{2}{*}{$39 / \mathrm{P} 1$} & 0-81 G.Bauru & $33,50-$ & & 1969 & exploraçāo & Janer & \\
\hline & $81-120$ S.Geral & 77,3 & & & & & \\
\hline \multirow[t]{2}{*}{$39 / \mathrm{P} 3$} & $0-67,5$ G.Bauru & 37,64 & $0-20,00$ & 1979 & exploraçăa & Waldemar Georg. & As margens do Córrego \\
\hline & 67,5-220 S.Geral & 70 & & & & e Cia Ltda. & Açoita Cavalo \\
\hline \multirow[t]{2}{*}{ 40/P 1} & 0-131 G.Bauru & 80 & $0-15,60$ & 1974 & exploração & Janer & \\
\hline & 131-150 S.Gera & 129,5 & & & & & \\
\hline \multirow[t]{2}{*}{ 40/P 2} & 0-140 G.Bauru & 98,89 & $0-18,00$ & 1993 & exploraçáo & & R. Espírito Santo, s. núm. \\
\hline & 140-146 S.Geral & 142,14 & & & & & \\
\hline \multirow[t]{2}{*}{$41 / \mathrm{P} 1$} & 0-117,5 G.Bauru & & $0-22,00$ & 1975 & exploraçăo & Passareli & \\
\hline & 117,5-120 S.Geral & & & & & & \\
\hline $41 / \mathrm{P} 2$ & 0-120 G.Bauru & & & 1976 & exploraçăp & IGG & \\
\hline \multirow[t]{2}{*}{$41 / \mathrm{P} 3$} & 0-69,69 G.Bauru & 32,44 & $0-16,00$ & 1987 & exploraçăo & Controli-Proj. $\theta$ & Confluência dos Córreg. \\
\hline & 69,69-221 S.Geral & 63,27 & & & & Const. Ltda. & Linguiça $\theta$ Duas Pontes \\
\hline \multirow[t]{2}{*}{$42 / \mathrm{P} 2$} & 0-31G.Bauru & & $0-35,5$ & 1979 & oxploraçăo & Hidrotécnica & As margens do Córrego \\
\hline & 31-160,6 S.Geral & & & & & & do Atolador \\
\hline \multirow[t]{2}{*}{$43 / P 3$} & 0-50 G.Bauru & & $0-12,00$ & 1985 & exploraçăo & Passarelli & Margem do Córrego \\
\hline & 50-180,5 S.Geral & & & & & & Januário Amaral \\
\hline $44 / \mathrm{P} 1$ & 0-95 G.Bauru & 52,63 & $0-1200$ & 1985 & exploraçăo & Passarelli & Próximo ao campo de \\
\hline & 95-96 S.Geral & 88,99 & & & & & futebol \\
\hline
\end{tabular}




\begin{tabular}{|c|c|c|c|c|c|c|c|c|c|c|}
\hline \multirow{3}{*}{45} & & & & & & $\operatorname{Cos} n$ & \multirow{2}{*}{$\frac{P_{R o t}}{150}$} & \multirow{2}{*}{$\begin{array}{c}\text { Ne } \\
0,27 \\
\end{array}$} & ND & $Q$ \\
\hline & Sud Mennucci & P4 & 739 & & $7711,50 / 510,30$ & 350 & & & 99 & 10 \\
\hline & & & & & & & & & & \\
\hline \multirow[t]{2}{*}{45} & & P5 & 1228 & & $7712,05 / 507,40$ & & ? & 32 & 59,53 & 30,46 \\
\hline & & & & & & & & & & \\
\hline \multirow[t]{2}{*}{46} & Tupinambá & P1 & 284 & & $7785,50 / 579,50$ & 460 & 98 & 30 & 78,09 & 4,5 \\
\hline & & & & & & & & & & \\
\hline \multirow[t]{2}{*}{47} & Turiuba & $\overline{P 2}$ & & 22DIV-4-3 & $7682,8 / 591,4$ & 410 & 186 & 70 & 81,34 & 20,3 \\
\hline & & & & & & & & & & \\
\hline \multirow[t]{2}{*}{48} & Turmalina & $\mathrm{P1}$ & 803 & & $7782,25 / 555$ & 460 & 120 . & 14,2 & 106,58 & 12,4 \\
\hline & & & & & & & & & & \\
\hline \multirow[t]{2}{*}{48} & & $\mathrm{P2}$ & 804 & & $7780,9 / 550$ & 420 & 165 & 9,48 & 92,01 & 7,47 \\
\hline & & & & & & & & & & 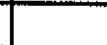 \\
\hline \multirow[t]{2}{*}{48} & & $P_{3}$ & 805 & & $7783,8 / 550,10$ & 420 & 180 & 9,95 & 92,81 & 7 \\
\hline & & & & & & & & & & 1 \\
\hline \multirow[t]{2}{*}{49} & União Paulista & $P 1$ & & $22 \times A V 1-3-5$ & $7689,55 / 614,75$ & 440 & 152 & 72,74 & 142,82 & 15,5 \\
\hline & & & & & & & & 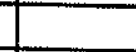 & & \\
\hline \multirow[t]{2}{*}{49} & & P 2 & 1172 & & $7689,90 / 612,10$ & 480 & 176 & 49,64 & 103,42 & 14,94 \\
\hline & & & & & & & 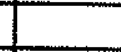 & 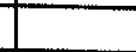 & & \\
\hline \multirow[t]{2}{*}{50} & Urânia & $\mathrm{P1}$ & 809 & & & & 160 & 40 & 99,8 & 8 \\
\hline & & & & & & & 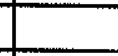 & & & \\
\hline \multirow[t]{2}{*}{50} & & $P 2$ & 810 & & & & 155 & 50 & 83,8 & 15 \\
\hline & & & & & & & & & & \\
\hline \multirow[t]{2}{*}{50} & & P3 & 811 & & & & 150 & 32 & 93,2 & 8 \\
\hline & & & & & & & & & & \\
\hline \multirow[t]{2}{*}{50} & & $P 4$ & 812 & & $7761,35 / 537,40$ & 450 & 109,21 & 24,27 & 69,84 & 18,8 \\
\hline & & & & & & & & & & \\
\hline \multirow[t]{2}{*}{50} & & P5 & 813 & SF22DI-2-15 & $7761,5 / 538,2$ & 430 & 75 & 4,56 & 60,54 & 13,65 \\
\hline & & & & & & & & & & \\
\hline 50 & & $P 6$ & 859 & & $7761,3 / 535,6$ & 460 & 115,59 & 10,2 & 96,4 & 17,21 \\
\hline & & & & & & & & & & \\
\hline 50 & & P 8 & 1226 & & $7762,25 / 536,25$ & 480 & 145 & 23,37 & 122,7 & 8,8 \\
\hline & & & & & & & & & & \\
\hline 50 & & P9 & & & $7763,40 / 539,25$ & 420 & 270 & & & 2,2 \\
\hline & & & & & & & & & & \\
\hline 51 & Vale Formoso & $P 1$ & 452 & & $7624+950 / 666$ & 460 & 121,5 & 21,33 & 80,6 & 2,5 \\
\hline & & & & & & & & & & \\
\hline 51 & & $\mathbf{P 2}$ & 453 & & $7726,65 / 664,65$ & 440 & 180 & 28 & 92,23 & 10 \\
\hline & & & & & & & & & & \\
\hline 52 & Valentim Gentil & P1 & & & $7742,20 / 595,35$ & 480 & 130 & 10 & & 10 \\
\hline & & & & & & & & & & \\
\hline 52 & & $P 2$ & 821 & & & & 170 & 16 & 107,5 & 6,5 \\
\hline & & & & & & & & & & \\
\hline 52 & & $P_{3}$ & 822 & & & & 163,5 & 60,5 & 104,5 & 8,6 \\
\hline & & & & & & & & & & \\
\hline 52 & & $\mathrm{P}^{4}$ & 823 & & & & 119 & 12 & 93 & 10,28 \\
\hline & & & & & & & & & & \\
\hline 52 & & P5 & & SF22DII-4-42 & $7740,65 / 596,1$ & 487 & 131,5 & 10,1 & 94,6 & 8,8 \\
\hline & & & & & & & & & & \\
\hline
\end{tabular}




\begin{tabular}{|c|c|c|c|c|c|c|c|}
\hline $45 / P 4$ & $0-110$ G.Bauru & $224,20^{-}$ & $0-12,00$ & 1981 & exploraçăo & Passarelli & Margem do Córrego \\
\hline & 110-150 S.Geral & 106,7 & & & & & Cateto \\
\hline \multirow[t]{2}{*}{$45 / \mathrm{P} 5$} & 0-122 G.Bauru & $58,82-$ & $0-18,00$ & 1991 & exploração & Politi/Contep & Area do futuro reservat. \\
\hline & $122-123,5$ S.Geral & 67,12 & & & & & da SABESP \\
\hline \multirow[t]{2}{*}{ 46/P 1} & 0-85 G.Bauru & 37,90 & $0-20,00$ & 1979 & exploraçăo & Waldemar Georg. & Vía Tupinambá, pátio \\
\hline & 85-98 S.Geral & 87,05 & & & & e Cia Ltda. & do Grupo Escolar \\
\hline \multirow[t]{2}{*}{ 47/P 2} & 0-85 G.Bauru & & $0-22,00$ & 1975 & exploração & Passarelli & Chácara S.Antónió, \\
\hline & 85-186 S.Geral & & & & & & junto ao Córr. da Mata \\
\hline \multirow[t]{2}{*}{$48 / \mathrm{P} 1$} & 0-78 G.Bauru & $42-$ & $0-10,00$ & 1975 & exploraçăo & Janer & Chácara Santa Maria \\
\hline & $78-120$ S.Geral & 79 & & & & & \\
\hline \multirow[t]{2}{*}{$48 / \mathrm{P} 2$} & 0-37 G.Bauru & & $0-10,20$ & 1981 & exploração & Passarelli & \\
\hline & 37-165 S.Geral & & & & & & \\
\hline \multirow[t]{2}{*}{$48 / P^{3}$} & 0-34 G.Bauru & & $0-12,00$ & 1982 & exploração & Hikdrogesp & Ás margens do Córrego \\
\hline & 34-180 S.Geral & & & & & & Candinho \\
\hline \multirow[t]{2}{*}{ 49/P 1} & 0-90 G.Bauru & 55,70 & $0-15,00$ & 1975 & exploraçăo & Passarelli & Salda para Nipoá, \\
\hline & $90-152$ S.Geral & 89 & & & & & direita \\
\hline \multirow[t]{2}{*}{ 49/P 2} & $0-122,5$ G.Bauru & & $0-12,00$ & 1989 & exploraçăo & Air Drill & R. 21 de março, 89 \\
\hline & 122,5-176 S.Geral & & & & & & \\
\hline \multirow[t]{2}{*}{$50 / P_{1}$} & 0-160 G.Bauru & & & & & & \\
\hline & & & & & & & \\
\hline \multirow[t]{2}{*}{$50 / P^{2}$} & 0 -155 G.Bauru & & & & & & \\
\hline & & & & & & & \\
\hline \multirow[t]{2}{*}{$50 / \mathrm{P}^{3}$} & $0-150$ G.Bauru & & & & & & \\
\hline & & & & & & & \\
\hline \multirow[t]{2}{*}{$50 / P 4$} & $0-102,60$ G.Bauru & $69,22-$ & $0-18,00$ & 1979 & exploraçăo & Waldemar Georg. & Nascente do Córrego \\
\hline & 102,60-109,21 S.Geral & 109,21 & & & & e Cia Ltda. & Comprido \\
\hline \multirow{2}{*}{$50 / P^{5}$} & 0-66 G.Bauru & $44,2-$ & $0-10$ & 1979 & exploraçăo & Hidrotécnica & Próximo à lagoa de trat. \\
\hline & $66-75$ S.Geral & 65,9 & & & & & esgoto da SABESP \\
\hline \multirow[t]{2}{*}{$50 / P^{6}$} & O-117 G.Bauru & $59,81-$ & $0-17,00$ & 1982 & exploraçåo & Hidrogesp & R. Gojás, próximo à horta \\
\hline & $117-115,6$ S. Geral & 112,53 & & & & & comunitária \\
\hline \multirow[t]{2}{*}{$50 / \mathrm{P} 8$} & 0-138 G.Bauru & & $0-18,00$ & 1991 & exploraçăo & Politi & Margem esquerda da \\
\hline & 138-145 S.Geral & & & & & & Rodov. Eucl. da Cunha \\
\hline \multirow[t]{2}{*}{$50 / \mathrm{P} 9$} & $0-67,60$ G.Bauru & & $0-18,00$ & 1995 & inexplorável & Geoplan & Próximo ao Córrego \\
\hline & $67,60-270$ S.Geral & & & & & & Comprido \\
\hline \multirow[t]{2}{*}{$51 / \mathrm{P}_{1}$} & 0-115 G.Bauru & $51-$ & $0-12,00$ & 1980 & exploraçăo & Copercal & Próximo ao Posto de \\
\hline & $115-121,5$ S.Geral & 118,34 & & & & & Saúde \\
\hline \multirow[t]{2}{*}{$51 / P^{2}$} & 0.72 G.Bauru & 37,17 & $0-12,00$ & 1981 & exploraçăo & Passarelli & Margens do Córrego \\
\hline & 72-180 S.Geral & 68,24 & & & & & Olho D Agua \\
\hline \multirow[t]{2}{*}{$52 / \mathrm{P}$} & 0-120 G.Bauru & & & & & & \\
\hline & $120-130$ S.Geral & & & & & & \\
\hline \multirow[t]{2}{*}{$52 / \mathrm{P} 2$} & $0-138$ G.Bauru & & & 1971 & exploraçäo & Janer & R. Dr. Augusto Alves dos \\
\hline & 138-170 S.Geral & & & & & & Reis \\
\hline \multirow[t]{2}{*}{$52 / \mathrm{P} 3$} & D-163,2 G.Bauru & & & 1971 & exploraçăo & Janer & Próximo ao reservatório \\
\hline & $163,2-163,5$ S.Geral & & & & & & elevado \\
\hline $52 / P 4$ & & & & 1976 & exploraçāo & Janer & \\
\hline & & & & & & & \\
\hline $52 / \mathrm{P} 5$ & 0-124 G.Bauru & $43,03-$ & $0-18,00$ & 1978 & exploraçẫo & Politi & Propriedede de Hermes \\
\hline & 124-131,5 S.Geral & 96,03 & & & & & D. Belintoni \\
\hline
\end{tabular}




\begin{tabular}{|c|c|c|c|c|c|c|c|c|c|}
\hline 52 & & P6 & 825 & $7742,85 / 595,15$ & 470 & 95 & jorrante & 70,54 & 8,51 \\
\hline 52 & & P 7 & 826 & $7740,45 / 544,95$ & 470 & 136,4 & 18,35 & 89,19 & 6,33 \\
\hline & & & & & & & & & \\
\hline 52 & & P 8 & 827 & $7740 / 596$ & 475 & 114,8 & 3,34 & 98 & 12 \\
\hline 53 & Vila Alves & $\mathbf{P 1}$ & & $7769,20 / 607,5$ & 470 & 220 & 18,5 & 129,3 & 5,17 \\
\hline & & & & 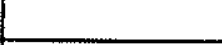 & & & & & \\
\hline 54 & Vitória Brasil & $P 1$ & 334 & $7766,80 / 554,50$ & 480 & 104 & 2,62 & 77,58 & 13,6 \\
\hline & & & & & & & & & \\
\hline
\end{tabular}




\begin{tabular}{|l|l|l|l|l|l|l|l|}
\hline 52/P 6 & $0-92$ G. Bauru & $33,50-$ & $0-22,00$ & 1979 & exploração & Hidrogesp & Próximo ao matadouro \\
\hline & $92-95$ S.Geral & 90 & & & & & \\
\hline 52/P 7 & $0-136$ G.Bauru & $52,05-$ & $0-12,00$ & 1980 & exploração & Hidrogesp & Nascente do Córrego \\
\hline & $136-136,4$ S.Geral & 135,65 & & & & & Amasco \\
\hline 52/P 8 & $0-114$ G.Bauru & $46,49-$ & $0-12,00$ & 1980 & exploração & Hidrogesp & Próximo ao Córrego \\
\hline & $114-114,8$ S.Geral & 110,97 & & & & & Viradouro \\
\hline 53/P 1 & $0-82$ G.Bauru & & & 1979 & exploração & Waldemar Georg. & \\
\hline & $82-220$ S.Geral & & & & & o Cia Ltda, & \\
\hline 54/P 1 & $0-94$ G.Bauru & & $0-3,00$ & 1979 & exploraçăo & Passarelli & \\
\hline & $94-107$ S.Geral & & & & & & \\
\hline
\end{tabular}


Anexo 02: Análises das águas subterrâneas feitas pela SABESP em 54 localidades da região noroeste do Estado de São Paulo.

\begin{tabular}{|c|c|c|c|c|c|c|c|}
\hline Localidade & $\begin{array}{l}\text { Poço } \\
\text { local }\end{array}$ & $\begin{array}{l}\text { Poģo } \\
\text { SABESP }\end{array}$ & $\begin{array}{l}\text { data de } \\
\text { coleta }\end{array}$ & \begin{tabular}{|l|} 
Cr total $(\mathrm{mg} / \mathrm{l})$ \\
valor máx. \\
perm. 0,05 \\
\end{tabular} & Cr hex. (mg/l) & \begin{tabular}{|l|} 
Nitrog. Nitrato \\
(mg/l) \\
valor máx. \\
perm. 10
\end{tabular} & $\begin{array}{r}\text { Cond.elét. } \\
(\mu \mathrm{mho} / \mathrm{cm}) \\
\text { à } 25^{\circ} \mathrm{C}\end{array}$ \\
\hline \multirow[t]{2}{*}{ Alvares Florence } & $P 1$ & 23 & $26 / 05 / 82$ & & 0,007 & 3,9 & 300 \\
\hline & & & $23 / 02 / 88$ & 0,015 & & 3,5 & 299 \\
\hline \multirow[t]{3}{*}{ Aparecida D' Oeste } & $P 1$ & & $29 / 07 / 87$ & 0,031 & & 0,24 & 175 \\
\hline & & & $27 / 06 / 88$ & 0,034 & & 0,74 & 149 \\
\hline & & & $22 / 02 / 89$ & 0,027 & & 0,5 & 163 \\
\hline Arabá (dist. de Guarani & P1 & & $13 / 10 / 80$ & 0,005 & & 0,16 & 200 \\
\hline $\mathrm{D}^{\prime}$ Oeste) & & & $19 / 06 / 86$ & 0,005 & & 0,09 & 210 \\
\hline \multirow[t]{29}{*}{ Aspásia } & $\mathrm{P1}$ & 815 & $29 / 02 / 80$ & 0,068 & & 0,15 & 500 \\
\hline & & & $05 / 01 / 83$ & 0,056 & & 0,1 & 490 \\
\hline & & & $25 / 06 / 87$ & 0,055 & 0,052 & 1,1 & 300 \\
\hline & & & $08 / 12 / 88$ & 0,042 & 0,04 & 0,09 & 271 \\
\hline & & & $09 / 12 / 88$ & 0,135 & 0,07 & 0,04 & 484 \\
\hline & & & $10 / 12 / 88$ & 0,087 & 0,076 & 0,04 & 497 \\
\hline & & & $11 / 12 / 88$ & 0,099 & 0,075 & 0,05 & 502 \\
\hline & & & $12 / 12 / 88$ & 0,105 & 0,073 & 0,05 & 509 \\
\hline & & & $14 / 12 / 88$ & & 0,067 & 0,05 & 369 \\
\hline & & & $16 / 12 / 88$ & & 0,071 & 0,05 & 382 \\
\hline & & & $19 / 12 / 88$ & 0,024 & 0,019 & 2,3 & 297 \\
\hline & & & $21 / 12 / 88$ & 0,074 & 0,074 & 0,36 & 436 \\
\hline & & & $09 / 01 / 89$ & & 0,073 & 0,23 & \\
\hline & & & $04 / 04 / 89$ & 0,067 & & 0,06 & 504 \\
\hline & & & $20 / 08 / 90$ & 0,021 & & & \\
\hline & & & $23 / 10 / 92$ & & 0,06 & & \\
\hline & & & $11 / 11 / 92$ & & 0,01 & & \\
\hline & & & $08 / 09 / 93$ & & 0,05 & & \\
\hline & $P 2$ & 816 & $26 / 02 / 81$ & 0,023 & & 0,08 & 215 \\
\hline & & & $11 / 11 / 92$ & & 0,04 & & \\
\hline & & & $03 / 12 / 93$ & & 0,05 & & \\
\hline & P 3 & 849 & $17 / 04 / 80$ & 0,064 & & 0,04 & 510 \\
\hline & & & $08 / 07 / 82$ & & 0,027 & 0,06 & 260 \\
\hline & & & $12 / 12 / 88$ & & 0,045 & 1,4 & 278 \\
\hline & & & $19 / 12 / 88$ & 0,047 & 0,047 & 1,3 & 235 \\
\hline & & & $21 / 12 / 88$ & 0,048 & 0,048 & 1,2 & 254 \\
\hline & & & $16 / 01 / 91$ & & 0,04 & & \\
\hline & & & $23 / 10 / 92$ & & 0,04 & & \\
\hline & & & $11 / 11 / 92$ & & 0,04 & & \\
\hline \multirow[t]{10}{*}{ Auriflama } & P2 & 72 & $26 / 04 / 84$ & 0,005 & & 12,3 & 450 \\
\hline & & & $09 / 02 / 88$ & 0,007 & & 1,4 & 342 \\
\hline & & & $28 / 02 / 89$ & 0,011 & & 1,6 & 418 \\
\hline & $\mathrm{P3}$ & 73 & $20 / 10 / 81$ & 0,005 & & 18,5 & 420 \\
\hline & & & $26 / 04 / 84$ & 0,005 & & & 470 \\
\hline & P6 & 76 & $10 / 02 / 84$ & 0,006 & & & \\
\hline & P7 & 77 & $26 / 04 / 84$ & 0,018 & & 3,7 & 260 \\
\hline & $P 10$ & 80 & $21 / 04 / 82$ & 0,029 & & 0,21 & 160 \\
\hline & $P 11$ & 81 & $04 / 05 / 82$ & 0,029 & & 0,21 & 160 \\
\hline & $\mathrm{P} 12$ & 878 & $30 / 12 / 82$ & 0,026 & & 4,1 & 230 \\
\hline
\end{tabular}




\begin{tabular}{|c|c|c|c|c|c|c|c|}
\hline Bandeirante D' Oeste (dist. & P 2 & 942 & $19 / 07 / 85$ & 0,013 & & 1,1 & 250 \\
\hline de'Sud Mennucci) & & & 193 & 0,06 & & & \\
\hline Boa Vista dos Andradas & $\mathrm{P} 1$ & 24 & $26 / 05 / 82$ & 0,014 & & 0,62 & 390 \\
\hline \multirow{2}{*}{ (dist. de Alvares Florence) } & & & $24 / 08 / 87$ & 0,01 & & 3,8 & 247 \\
\hline & & & $28 / 02 / 89$ & 0,015 & & 1,8 & 225 \\
\hline Cardoso & $\mathbf{P 1}$ & 160 & $15 / 02 / 89$ & 0,007 & & 0,86 & 153 \\
\hline Dalas (dis. de Palm. D'Oeste) & $\mathrm{P1}$ & & $27 / 06 / 80$ & 0,031 & & 0,04 & 200 \\
\hline \multirow[t]{5}{*}{ Dirce Reis } & $P 1$ & 651 & $06 / 07 / 93$ & 0,09 & & & \\
\hline & & & $12 / 08 / 93$ & 0,07 & & & \\
\hline & & & $30 / 09 / 93$ & 0,1 & & & \\
\hline & & & $26 / 10 / 93$ & 0,9 & & & \\
\hline & P2 & 1013 & $26 / 10 / 93$ & 0,1 & & & \\
\hline \multirow[t]{5}{*}{ Dolcinópolis } & $P 1$ & & $02 / 04 / 87$ & 0,006 & & 3,8 & 165 \\
\hline & & & $09 / 03 / 88$ & 0,024 & & 3,7 & 125 \\
\hline & & & 14/03/89 & 0,031 & & 6,1 & 245 \\
\hline & $\overline{P 3}$ & 1321 & $30 / 10 / 92$ & 0,06 & & 0,04 & 191 \\
\hline & & & $25 / 10 / 93$ & 0,06 & & & \\
\hline \multirow[t]{5}{*}{ Dulcelina (dist. de Pedran.) } & P1 & 1026 & $11 / 12 / 86$ & 0,013 & & 0,04 & 140 \\
\hline & & & $14 / 04 / 87$ & 0,005 & & 0,04 & 135 \\
\hline & & & $15 / 10 / 87$ & 0,016 & & 0,21 & 95 \\
\hline & & & $20 / 10 / 88$ & 0,015 & & 0,21 & 110 \\
\hline & & & $01 / 03 / 89$ & 0,012 & & 0,23 & 109 \\
\hline \multirow[t]{4}{*}{ Esmeraida (dist. de Rubinéia) } & $\mathrm{P}_{1}$ & 598 & $04 / 04 / 81$ & 0,016 & & 3,5 & 90 \\
\hline & & & $06 / 07 / 87$ & 0,021 & & 3,2 & 200 \\
\hline & & & 17/05/88 & 0,024 & & 3, ब & 84 \\
\hline & & & 189 & 0,03 & & 3 & 99 \\
\hline \multirow[t]{6}{*}{ Estrela D' Oeste } & P5 & 211 & 19/01/81 & 0,023 & & 0,64 & 320 \\
\hline & & & $02 / 03 / 89$ & & 0,028 & & 268 \\
\hline & P6 & & $04 / 02 / 81$ & 0,042 & & 0,43 & 250 \\
\hline & & & $02 / 03 / 80$ & & 0,052 & & 217 \\
\hline & P7 & 213 & $26 / 10 / 81$ & 0,024 & & 0,04 & 250 \\
\hline & & & $02 / 03 / 89$ & & 0,045 & & 226 \\
\hline Fátima Paulista (dist. de & $\mathrm{P} 1$ & 805 & $21 / 07 / 93$ & 0,05 & & & \\
\hline Turmalina) & & & $16 / 08 / 93$ & 0,05 & & & \\
\hline \multirow[t]{4}{*}{ Fernandópolis } & P 15 & & $22 / 02 / 89$ & & 0,012 & 0,04 & 454 \\
\hline & P16 & & $21 / 02 / 80$ & & 0,005 & 0,04 & 413 \\
\hline & P 17 & 1068 & 12/11/87 & & 0,015 & 0,04 & 441 \\
\hline & & & $21 / 02 / 89$ & & 0,012 & 0,04 & 417 \\
\hline \multirow[t]{3}{*}{ Gastão Vidigal } & 95 & 879 & $05 / 11 / 80$ & 0,021 & & 0,02 & 0,02 \\
\hline & $P 6$ & 903 & $15 / 09 / 84$ & 0,025 & & 0,56 & 320 \\
\hline & $\mathrm{P7}$ & 909 & $19 / 10 / 84$ & 0,006 & & 5,64 & 120 \\
\hline \multirow[t]{4}{*}{ Guzolândia } & P2 & 970 & $06 / 11 / 85$ & 0,03 & 0,016 & 0,04 & 310 \\
\hline & & & $06 / 12 / 85$ & 0,032 & 0,005 & 0,05 & 200 \\
\hline & $\mathrm{P3}$ & 1080 & $06 / 12 / 88$ & 0,035 & & & 232 \\
\hline & & & $04 / 11 / 93$ & 0,08 & & & \\
\hline Ida lolanda (dist. Nhandeara) & P1 & & $29 / 03 / 79$ & 0,018 & & 1,1 & 220 \\
\hline \multirow[t]{7}{*}{ Indiaporá } & $\mathrm{P} 1$ & $27 \sqrt{2}$ & 05/10/80 & 0,006 & & 0,36 & 300 \\
\hline & & & $03 / 07 / 87$ & 0,015 & & 2 & 280 \\
\hline & & & $06 / 10 / 88$ & 0,011 & & 1,8 & 248 \\
\hline & $\mathrm{P2}$ & & $05 / 10 / 93$ & 0,05 & & & \\
\hline & $\mathrm{P3}$ & & $18 / 10 / 80$ & 0,005 & & 0,41 & 160 \\
\hline & P4 & & $12 / 10 / 80$ & 0,008 & & 4,9 & 220 \\
\hline & P5 & & $06 / 10 / 88$ & 0,022 & & \begin{tabular}{l|l}
0,27 \\
\end{tabular} & 191 \\
\hline
\end{tabular}




\begin{tabular}{|c|c|c|c|c|c|c|c|}
\hline Jales & $\mathrm{P} 1$ & 326 & $28 / 02 / 80$ & 0,037 & & 0,69 & 200 \\
\hline & & & $05 / 08 / 87$ & 0,017 & & 1,7 & 360 \\
\hline & & & $03 / 03 / 88$ & 0,011 & & 0,91 & 360 \\
\hline & $P 2$ & 327 & $15 / 02 / 80$ & 0,056 & & 0,8 & 180 \\
\hline & & & $02 / 09 / 87$ & 0,016 & & 3.4 & 242 \\
\hline & & & $06 / 06 / 88$ & 0,018 & & 1,1 & 228 \\
\hline & & & $27 / 12 / 93$ & 0,05 & & & \\
\hline & P3 & 328 & $08 / 03 / 80$ & 0,023 & & 1,1 & 250 \\
\hline & & & $27 / 12 / 93$ & 0,05 & & & \\
\hline & $P 4$ & 329 & $07 / 05 / 80$ & 0,034 & & 1,5 & 150 \\
\hline & $P 21$ & 1311 & $13 / 07 / 92$ & 0,005 & & 0,04 & 275 \\
\hline & & & $17 / 07 / 92$ & & 0,005 & 0,04 & 255 \\
\hline \multirow[t]{5}{*}{ Macodónia } & $\mathrm{P1}$ & & $13 / 05 / 81$ & 0,014 & & 0,06 & 150 \\
\hline & & & $15 / 10 / 87$ & 0,017 & & 0,88 & 148 \\
\hline & & & $09 / 08 / 88$ & 0,021 & & 0,7 & $\overline{145}$ \\
\hline & $\mathbf{P 2}$ & 391 & $10 / 04 / 81$ & 0,039 & & 0,12 & 180 \\
\hline & P3 & 907 & $05 / 10 / 84$ & 0,008 & & 0,04 & 160 \\
\hline Mangaratu (dist. de Nova & $P 1$ & 835 & $25 / 04 / 82$ & 0,075 & & 0,04 & 120 \\
\hline Granada) & & & 183 & 0,108 & & & \\
\hline \multirow[t]{7}{*}{ Marinópolis } & P2 & 1171 & $13 / 11 / 89$ & 0,074 & 0,063 & 2,7 & 230 \\
\hline & & & $29 / 07 / 93$ & 0,08 & & 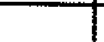 & \\
\hline & $\mathrm{P3}$ & 1256 & $22 / 11 / 91$ & 0,096 & 0,085 & 0,04 & 160 \\
\hline & & & $05 / 02 / 92$ & 0,008 & 0,005 & 0,09 & 238 \\
\hline & & & $29 / 07 / 93$ & 0,05 & & 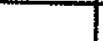 & \\
\hline & $\mathrm{P4}$ & 1318 & $22 / 09 / 92$ & 0,032 & 0,032 & 0,12 & 556 \\
\hline & & & $29 / 07 / 93$ & 0,05 & & & \\
\hline \multirow[t]{2}{*}{ Mesópolis (dist. Paranapuâ) } & P1 & & $25 / 02 / 80$ & 0,036 & & 0,54 & 225 \\
\hline & & & $06 / 05 / 80$ & 0,018 & & 0,16 & 180 \\
\hline \multirow[t]{7}{*}{ Mira Estrela } & P1 & & $15 / 10 / 87$ & 0,012 & & 0,74 & 180 \\
\hline & & & $23 / 05 / 88$ & 0,037 & & 1,6 & 202 \\
\hline & & & $02 / 12 / 93$ & 0,07 & & & \\
\hline & P4 & 406 & $25 / 09 / 80$ & 0,005 & & 0,29 & 200 \\
\hline & P5 & 407 & $08 / 03 / 81$ & 0,021 & & 0,27 & 210 \\
\hline & $P 6$ & 910 & $14 / 11 / 84$ & 0,01 & & 0,11 & 290 \\
\hline & P7 & 1038 & $04 / 06 / 87$ & & 0,005 & 0,04 & 240 \\
\hline \multirow[t]{2}{*}{ Monçరes } & P1 & 416 & $09 / 07 / 87$ & 0,012 & & 0,09 & 200 \\
\hline & & & $27 / 10 / 88$ & 0,009 & & 0,08 & 167 \\
\hline \multirow[t]{3}{*}{ Nova Lusitânia } & P4 & 889 & $26 / 05 / 83$ & 0,005 & & 0,05 & 140 \\
\hline & $\longdiv { P 5 }$ & 1128 & $29 / 02 / 88$ & 0,006 & & & 59 \\
\hline & $P 6$ & 1238 & $28 / 08 / 91$ & 0,011 & & 0,04 & 181 \\
\hline \multirow[t]{4}{*}{ Palmeira D' Oeste } & $\mathbf{P 1}$ & & $12 / 03 / 90$ & 0,005 & & 0,23 & 186 \\
\hline & $P 2$ & & $12 / 03 / 90$ & 0,005 & & 0,19 & 186 \\
\hline & P8 & 467 & $18 / 10 / 79$ & 0,018 & & 0,52 & 300 \\
\hline & $\mathrm{P9}$ & 468 & $05 / 09 / 79$ & 0,032 & & 0,04 & 150 \\
\hline Paranapuă & P3 & & $29 / 12 / 79$ & 0,018 & & 1,47 & 240 \\
\hline \multirow[t]{8}{*}{ Pedranópolis } & $\mid P_{1}$ & 480 & $28 / 05 / 81$ & 0,031 & & 0,25 & 80 \\
\hline & & & $11 / 05 / 84$ & 0,02 & & 0,43 & 70 \\
\hline & & & $05 / 05 / 87$ & 0,043 & & 0,32 & 125 \\
\hline & & & 13/07/87 & 0,052 & & 0,28 & 120 \\
\hline & & & $31 / 10 / 89$ & 0,034 & & 0,54 & 100 \\
\hline & P3 & 482 & $04 / 07 / 80$ & 0,041 & & 0,05 & 200 \\
\hline & P4 & 902 & $13 / 09 / 84$ & 0,085 & 0,046 & 0,04 & 200 \\
\hline & & & $15 / 01 / 86$ & 0,076 & 0,076 & 0,04 & 140 \\
\hline
\end{tabular}




\begin{tabular}{|c|c|c|c|c|c|c|c|}
\hline & P5 & 943 & $20 / 07 / 85$ & & 0,005 & 0,07 & 28 \\
\hline & P6 & 1037 & $05 / 06 / 87$ & & 0,005 & 0,04 & 80 \\
\hline \multirow[t]{4}{*}{ Pontalinda (dist. de Jales) } & $P_{1}$ & 331 & $23 / 08 / 79$ & 0,047 & & 0,1 & 160 \\
\hline & $\mathrm{P} 2_{2}$ & 332 & $15 / 02 / 80$ & 0,09 & & 0,04 & 120 \\
\hline & & & $18 / 09 / 87$ & 0,08 & & 0,04 & 103 \\
\hline & $P 3$ & 333 & $16 / 05 / 80$ & 0,005 & & 0,08 & 160 \\
\hline \multirow[t]{2}{*}{ Riolándia } & P5 & 924 & $08 / 02 / 85$ & 0,008 & & 0,06 & 700 \\
\hline & P6 & 975 & 18/01/86 & 0,006 & & 0,04 & 1000 \\
\hline \multirow[t]{4}{*}{ Rubinéia } & $\mathrm{P}_{1}$ & 597 & $21 / 10 / 80$ & 0,006 & & 1,9 & 180 \\
\hline & & & $20 / 07 / 87$ & 0,017 & & 0,85 & 200 \\
\hline & & & $22 / 11 / 88$ & 0,008 & & 0,09 & 186 \\
\hline & & & 05/09/89 & 0,011 & & 0,98 & 156 \\
\hline \multirow[t]{3}{*}{ Santa Albertina } & $P 1$ & & $20 / 07 / 87$ & 0,016 & & 0,23 & 300 \\
\hline & & & $03 / 05 / 88$ & 0,013 & & 0,31 & 233 \\
\hline & & & $29 / 08 / 89$ & 0,016 & & 0,32 & 265 \\
\hline \multirow[t]{6}{*}{ Santa Clara D' Oeste } & P1 & & $04 / 03 / 82$ & 0,62 & & 0,55 & 260 \\
\hline & & & $01 / 09 / 82$ & & 0,045 & 0,81 & 280 \\
\hline & & & $13 / 08 / 87$ & 0,04 & & 0,89 & 257 \\
\hline & & & $23 / 08 / 88$ & 0,043 & & 0,64 & 251 \\
\hline & & & $05 / 09 / 89$ & 0,034 & & 1 & 246 \\
\hline & $\mathrm{P2}$ & 846 & $22 / 05 / 82$ & 0,058 & & 0,46 & 320 \\
\hline S. Isab.do Marinh.(d.Pedran.) & $\mathrm{P1}$ & 483 & $11 / 10 / 80$ & 0,008 & & 0,04 & 180 \\
\hline \multirow{2}{*}{ Santa Salete (dist. de Urânia) } & $\overline{P 1}$ & & $20 / 08 / 90$ & 0,123 & & & \\
\hline & & & $03 / 12 / 93$ & 0,12 & & & \\
\hline \multirow[t]{6}{*}{ Santana da Ponte Pensa } & $\mathrm{P} 1$ & & $30 / 09 / 87$ & 0,034 & & 1,6 & 254 \\
\hline & & & $18 / 07 / 88$ & 0,041 & & 1,8 & 233 \\
\hline & & & $28 / 08 / 89$ & 0,042 & & 1,6 & 240 \\
\hline & & & $20 / 08 / 90$ & 0,073 & & 0,77 & 270 \\
\hline & $P_{2}$ & & $02 / 07 / 79$ & 0,021 & & 0,12 & 300 \\
\hline & & & $20 / 08 / 90$ & 0,073 & & 0,77 & 270 \\
\hline \multirow[t]{6}{*}{ Săo Francisco } & P1 & & $21 / 09 / 87$ & 0,063 & & 0,36 & 152 \\
\hline & & & $06 / 06 / 88$ & 0,033 & & 0,9 & 159 \\
\hline & & & $20 / 08 / 90$ & 0,047 & & & \\
\hline & & & $22 / 02 / 93$ & 0,06 & & & \\
\hline & & & $26 / 10 / 93$ & 0,07 & & & \\
\hline & P2 & & $04 / 11 / 93$ & 0,05 & 0,044 & 0,04 & 148 \\
\hline \multirow[t]{7}{*}{ Săo Joāo das Duas Pontos } & $P 1$ & 652 & $18 / 05 / 84$ & 0,05 & & 1,8 & 215 . \\
\hline & & & $30 / 09 / 87$ & 0,024 & & 0,36 & 135 \\
\hline & & & $06 / 05 / 93$ & 0,08 & & & \\
\hline & P2 & 653 & $18 / 05 / 84$ & 0,04 & & 2,8 & 150 \\
\hline & & & $06 / 05 / 93$ & 0,07 & & & \\
\hline & $P 3$ & 1040 & $08 / 06 / 87$ & 0,059 & 0,059 & 0,04 & 170 \\
\hline & & & $06 / 05 / 93$ & 0,07 & & & \\
\hline S.Joâo do Marinh.(d. Cardoso) & $\mathrm{P2}$ & & $21 / 11 / 79$ & 0,016 & & 0,04 & 180 \\
\hline Sebastianópolis do Sul & $\overline{P 3}$ & 933 & $17 / 05 / 85$ & 0,005 & 0,005 & 0,04 & 410 \\
\hline Socimbra & $\mathrm{P} 1$ & 938 & $25 / 05 / 85$ & 0,02 & & 0,04 & 340 \\
\hline \multirow[t]{5}{*}{ Sud Mennucci } & $P 4$ & 739 & $08 / 05 / 81$ & 0,039 & & 0,06 & \\
\hline & & & $14 / 12 / 93$ & 0,12 & & & \\
\hline & $\mathrm{P5}$ & 1223 & $16 / 08 / 88$ & 0,044 & & 1,6 & 222 \\
\hline & & & $07 / 12 / 91$ & 0,07 & 0,053 & 1,1 & 282 \\
\hline & & & $14 / 12 / 93$ & 0,07 & & & \\
\hline \multirow[t]{2}{*}{ Tupinambá } & $\mathrm{P} 1$ & 284 & $24 / 09 / 87$ & 0,038 & & 0,27 & 216 \\
\hline & & & $06 / 10 / 88$ & 0,022 & & 0,27 & 191 \\
\hline
\end{tabular}




\begin{tabular}{|c|c|c|c|c|c|c|c|}
\hline Turiuba & P2 & & $27 / 04 / 84$ & 0,005 & & 0,09 & 510 \\
\hline \multirow[t]{6}{*}{ Turmalina } & $\mathrm{P} 1_{1}$ & 803 & $22 / 10 / 87$ & 0,026 & & 2,9 & 338 \\
\hline & & & $19 / 07 / 88$ & 0,033 & & 1,4 & 267 \\
\hline & & & $11 / 09 / 89$ & 0,028 & & 0,26 & 298 \\
\hline & $\mathbf{P 2}$ & 804 & $11 / 08 / 81$ & 0,044 & & 0,04 & 320 \\
\hline & $P 3$ & 805 & $02 / 07 / 82$ & & 0,034 & 0,04 & 370 \\
\hline & & & $21 / 07 / 93$ & 0,05 & & & \\
\hline \multirow[t]{2}{*}{ Uniâo Paulista } & $\mathrm{P} 1$ & & \begin{tabular}{|c|}
$05 / 09 / 89$ \\
\end{tabular} & 0,031 & & 0,04 & 128 \\
\hline & P2 & 1172 & $20 / 11 / 89$ & 0,13 & 0,023 & 0,59 & 199 \\
\hline \multirow[t]{44}{*}{ Urânia } & P1 & 809 & $24 / 08 / 77$ & 0,07 & & 0,33 & 120 \\
\hline & & & $27 / 09 / 77$ & 0,03 & & & \\
\hline & & & \begin{tabular}{|c|}
$06 / 12 / 78$ \\
\end{tabular} & 0,037 & & 0,3 & 160 \\
\hline & & & $07 / 104 / 79$ & 0,076 & & 0,21 & 150 \\
\hline & & & $25 / 04 / 79$ & 0,041 & & 0,84 & 170 \\
\hline & & & $12 / 03 / 80$ & 0,052 & & 1 & 180 \\
\hline & & & $02 / 19 / 80$ & 0,074 & 0,072 & & \\
\hline & & & $18 / 03 / 81$ & 0,068 & 0,068 & 0,89 & 170 \\
\hline & & & $26 / 05 / 81$ & 0,055 & & 0,6 & 170 \\
\hline & & & $24 / 11 / 81$ & 0,054 & & 0,86 & 180 \\
\hline & & & $28 / 04 / 82$ & 0,047 & & 0,91 & 160 \\
\hline & & & $27 / 10 / 82$ & 0,051 & & 0,54 & 170 \\
\hline & & & $18 / 01 / 83$ & 0,065 & 0,065 & 0,6 & 160 \\
\hline & & & $13 / 04 / 83$ & 0,023 & 0,02 & & \\
\hline & & & $24 / 05 / 83$ & 0,023 & & & \\
\hline & & & $16 / 10 / 84$ & 0,032 & 0,012 & 1,1 & 105 \\
\hline & & & $26 / 06 / 87$ & 0,023 & 0,023 & 1 & 120 \\
\hline & & & $20 / 08 / 87$ & 0,05 & & 1 & 151 \\
\hline & & & $20 / 01 / 88$ & 0,102 & & 2,7 & 160 \\
\hline & & & $06 / 10 / 88$ & 0,056 & & 0,83 & 159 \\
\hline & & & $03 / 11 / 88$ & 0,078 & 0,026 & & \\
\hline & & & \begin{tabular}{|c|}
$03 / 10 / 89$ \\
\end{tabular} & 0,062 & & 1,3 & 135 \\
\hline & & & $20 / 08 / 90$ & 0,122 & & & \\
\hline & & & $23 / 10 / 92$ & & 0,02 & & \\
\hline & $\overline{P 2}$ & 810 & $24 / 08 / 77$ & 0,04 & & & 110 \\
\hline & & & $27 / 09 / 77$ & 0,05 & & & \\
\hline & & & $13 / 04 / 83$ & 0,08 & 0,08 & & \\
\hline & & & $24 / 05 / 83$ & 0,1 & & & \\
\hline & & & $16 / 10 / 84$ & 0,155 & 0,06 & 0,71 & 140 \\
\hline & & & $26 / 06 / 87$ & 0,073 & 0,073 & 1 & 190 \\
\hline & & & $20 / 08 / 90$ & 0,054 & & & \\
\hline & & & $23 / 10 / 92$ & & 0,09 & & \\
\hline & & & $01 / 12 / 93$ & 0,09 & & & \\
\hline & P3 & 811 & $24 / 08 / 77$ & 0,04 & & & 230 \\
\hline & & & $27 / 09 / 77$ & 0,03 & & & \\
\hline & & & $13 / 04 / 83$ & 0,011 & 0,009 & & \\
\hline & & & $24 / 05 / 83$ & 0,02 & & & \\
\hline & & & $16 / 10 / 84$ & 0,035 & 0,012 & 3,7 & 250 \\
\hline & & & $26 / 06 / 87$ & 0,024 & 0,024 & 3,9 & 180 \\
\hline & & & $20 / 01 / 88$ & 0,043 & & 1,7 & 263 \\
\hline & & & $20 / 08 / 90$ & 0,043 & & & \\
\hline & & & $23 / 10 / 92$ & & 0,02 & & \\
\hline & P4 & 812 & $24 / 08 / 77$ & 0,05 & & 0,63 & 180 \\
\hline & & & $27 / 09 / 77$ & 0,05 & & & \\
\hline
\end{tabular}




\begin{tabular}{|c|c|c|c|c|c|c|c|}
\hline & & & $24 / 05 / 83$ & 0,096 & 0,096 & & \\
\hline & & & $16 / 10 / 84$ & 0,09 & 0,036 & 0,12 & 140 \\
\hline & & & $26 / 06 / 87$ & 0,11 & 0,11 & 0,09 & 160 \\
\hline & & & $20 / 08 / 90$ & 0,059 & & & \\
\hline & & & $23 / 10 / 92$ & & 0,09 & & \\
\hline & & & $01 / 12 / 93$ & 0,1 & & & \\
\hline & P5 & 813 & $26 / 05 / 81$ & 0,052 & & 0,76 & 180 \\
\hline & & & 13/04/83 & 0,09 & 0,09 & & \\
\hline & & & $16 / 10 / 84$ & 0,11 & 0,08 & 0,08 & 150 \\
\hline & & & $26 / 06 / 87$ & 0,108 & 0,108 & 0,07 & 160 \\
\hline & & & $20 / 08 / 90$ & 0,065 & & & \\
\hline & & & $23 / 10 / 92$ & & 0,09 & & \\
\hline & & & $01 / 12 / 93$ & 0,09 & & & \\
\hline & P6 & 859 & $30 / 09 / 82$ & & 0,026 & 2,2 & 180 \\
\hline & & & $01 / 10 / 82$ & & 0,006 & 4,3 & 225 \\
\hline & & & $13 / 04 / 83$ & 0,107 & 0,104 & & \\
\hline & & & $16 / 10 / 84$ & 0,054 & 0,036 & 1,7 & 150 \\
\hline & & & $26 / 06 / 87$ & 0,012 & 0,012 & 5,1 & 210 \\
\hline & & & 20/08/90 & 0,014 & & & \\
\hline & & & $23 / 10 / 92$ & & 0,05 & & \\
\hline & & & $01 / 12 / 93$ & 0,09 & & & \\
\hline & P8 & 1226 & $23 / 10 / 92$ & & 0,09 & & \\
\hline & & & $01 / 12 / 93$ & 0,05 & & & \\
\hline Vale Formoso (dist. de Novo & $P 1$ & 452 & $26 / 05 / 80$ & 0,016 & & 0,04 & 220 \\
\hline Horizonte) & $\mathrm{P2}$ & 453 & $03 / 04 / 81$ & 0,074 & & 0,04 & 440 \\
\hline Valentim Gentil & $P 1$ & & $06 / 01 / 78$ & 0,04 & & 0,06 & 150 \\
\hline & & & $02 / 10 / 80$ & 0,039 & & 0,08 & 140 \\
\hline & $\overline{P 2}$ & 821 & $05 / 05 / 93$ & 0,05 & & & \\
\hline & $\mathbf{P 3}$ & 822 & 06/01/78 & 0,054 & & 0,3 & 200 \\
\hline & & & $01 / 10 / 80$ & 0,024 & & 7,3 & 160 \\
\hline & & & $30 / 03 / 93$ & 0,05 & & & \\
\hline & P4 & 823 & \begin{tabular}{|l|}
$06 / 01 / 78$ \\
\end{tabular} & 0,076 & & 0,04 & 200 \\
\hline & & & $27 / 09 / 80$ & 0,061 & 0,061 & 0,45 & 180 \\
\hline & P5 & & $20 / 09 / 80$ & 0,01 & & 5,2 & 160 \\
\hline & P6 & 825 & $30 / 03 / 93$ & 0,06 & & & \\
\hline & & & 17/12/93 & 0,07 & & & \\
\hline & P7 & 826 & 14/07/80 & 0,044 & & 0,28 & 170 \\
\hline & & & $11 / 10 / 88$ & 0,014 & & 1,7 & 250 \\
\hline & & & $30 / 03 / 93$ & 0,05 & & & \\
\hline & & & $17 / 12 / 93$ & 0,06 & & & \\
\hline & P8 & 827 & $05 / 08 / 80$ & 0,021 & & 2,2 & 200 \\
\hline & & & $16 / 11 / 88$ & 0,012 & & 0,23 & 190 \\
\hline Vila Alves (dist. de Cardoso) & P1 & & $23 / 07 / 79$ & 0,006 & & 4,8 & 340 \\
\hline Vitória Brasil (dist. de Jales) & $\mathbf{P 1}$ & 334 & \begin{tabular}{|l|}
$21 / 03 / 79$ \\
\end{tabular} & 0,018 & & 0,35 & 170 \\
\hline
\end{tabular}


Anexo 03: Descrição sucinta das 11 amostras de basaltos do poço 9 em Urânia, a diferentes profundidades.

\section{0 metros}

Alguns fragmentos possuem uma crosta avermelhada (oxidação) e esbranquiçada (possível de ver a olho nu). A textura é fanerítica fina. Existem minerais róseos a avermelhados em grande quantidade. Em seguida, minerais claros e escuros, sendo estes últimos, em menor quantidade. Não são encontradas vesículas na amostra.

\section{0 metros}

Alguns fragmentos possuem uma crosta esbranquiçada quando vistos a olho nu. A amostra não possui vesículas e sua textura é fanerítica fina. Os minerais claros predominam sobre os escuros.

\section{0 metros}

Esta amostra pode ser considerada como sendo do topo do derrame, por ser menos densa do que as outras, apresentar muitas vesículas não preenchidas e cor avermelhada. Alguns fragmentos apresentam uma crosta esverdeada.

\section{0 metros}

Esta amostra possui grãos claros, provalvelmente de calcita. Sua textura é fanerítica fina e os minerais claros predominam sobre os escuros.

\section{0 metros}

Amostra com textura fanerítica fina, sem vesículas. Os minerais claros predominam sobre os escuros. Aparecem alguns grãos maiores que provalvelmente são de calcita. 


\section{0 metros}

Os minerais claros predominam sobre os escuros. A amostra não apresenta vesículas e possui uma textura fanerítica fina.

\section{0 metros}

A amostra possui fragmentos de mineral claro, provavelmente calcita. Alguns fragmentos possuem uma crosta esverdeada. A textura é fanerítica fina, sem vesículas. Os minerais claros predominam sobre os escuros.

\section{0 metros}

Amostra com textura fanerítica fina, sem vesículas. Os minerais claros predominam sobre os escuros.

\section{0 metros}

Idem 210 metros

\section{0 metros}

Existem grãos provavelmente de calcita. Alguns fragmentos possuem uma crosta esverdeada. A textura é fanerítica fina. Os minerais claros predominam sobre os escuros.

\section{0 metros}

Idem 250 metros, não possuindo apenas a crosta esverdeada. 